\title{
CONTINENTAL RENOVATION
}

\section{UPGRADING NORTH AMERICAN ARCHITECTURE THROUGH THE SECURITY AND PROSPERITY PARTNERSHIP}

\author{
By \\ STEVEN MASSON, B.A.
}
A thesis submitted to
The Faculty of Graduate Studies and Research
in partial fulfillment of
the requirements for the degree of
Master of Arts

The Norman Paterson School of International Affairs

Carleton University

Ottawa, ON

April 21, 2008

(C) 2008, Steven Masson 


$\begin{array}{ll}\begin{array}{l}\text { Library and } \\ \text { Archives Canada }\end{array} & \begin{array}{l}\text { Bibliothèque et } \\ \text { Archives Canada }\end{array} \\ \begin{array}{l}\text { Published Heritage } \\ \text { Branch }\end{array} & \begin{array}{l}\text { Direction du } \\ \text { Patrimoine de l'édition }\end{array} \\ \begin{array}{l}\text { 395 Wellington Street } \\ \text { Ottawa ON K1A 0N4 } \\ \text { Canada }\end{array} & \begin{array}{l}\text { 395, rue Wellington } \\ \text { Ottawa ON K1A 0N4 } \\ \text { Canada }\end{array}\end{array}$

Your file Votre référence ISBN: 978-0-494-40604-5 Our file Notre référence ISBN: 978-0-494-40604-5

NOTICE:

The author has granted a nonexclusive license allowing Library and Archives Canada to reproduce, publish, archive, preserve, conserve, communicate to the public by telecommunication or on the Internet, loan, distribute and sell theses worldwide, for commercial or noncommercial purposes, in microform, paper, electronic and/or any other formats.

The author retains copyright ownership and moral rights in this thesis. Neither the thesis nor substantial extracts from it may be printed or otherwise reproduced without the author's permission.
AVIS:

L'auteur a accordé une licence non exclusive permettant à la Bibliothèque et Archives Canada de reproduire, publier, archiver, sauvegarder, conserver, transmettre au public par télécommunication ou par l'Internet, prêter, distribuer et vendre des thèses partout dans le monde, à des fins commerciales ou autres, sur support microforme, papier, électronique et/ou autres formats.

L'auteur conserve la propriété du droit d'auteur et des droits moraux qui protège cette thèse. $\mathrm{Ni}$ la thèse ni des extraits substantiels de celle-ci ne doivent être imprimés ou autrement reproduits sans son autorisation.
In compliance with the Canadian Privacy Act some supporting forms may have been removed from this thesis.

While these forms may be included in the document page count, their removal does not represent any loss of content from the thesis.
Conformément à la loi canadienne sur la protection de la vie privée, quelques formulaires secondaires ont été enlevés de cette thèse.

Bien que ces formulaires aient inclus dans la pagination, il n'y aura aucun contenu manquant.

\section{Canada}




\begin{abstract}
This paper analyzes the origins of the Security and Prosperity Partnership of North America (SPP) through the multiple streams model of public policy analysis. This analysis reveals that the SPP was designed with the intention of upgrading architecture for managing the North American relationship. The three features of this new architecture are: structuring a trilateral partnership on a two-speed approach; expanding a system of managing continental policy initiatives from the centre of government; and creating a framework that treats security and prosperity as co-dependent. The analysis of the three streams contained in the model explains why and how policy actors in Canada, the United States and Mexico selected a process-driven initiative as their favoured policy option.
\end{abstract}




\section{ACKNOWLEDGEMENTS}

I would like to acknowledge and express my sincerest gratitude to my thesis supervisor, Professor Norman Hillmer, for his constant support and guidance over this past year. Even before I embarked on this research project, he dedicated significant time toward helping me define my research interests and select a satisfying topic. He has since been there to guide me every step of the way. Time and again, he went above and beyond the supervisory requirements to ensure that I had a positive and rewarding experience completing this research. I could not have asked for a more supportive and dedicated research supervisor. I am also indebted to my thesis advisor, Dr. Peter Boehm. Despite his hectic schedule and the demands of managing Canada's North American relationship, Dr. Boehm was always available whenever I needed to meet with him. In addition, he was very generous in opening many doors to me in the policy community in all three countries, so that I could conduct my research interviews. It has been a privilege and honour to work with both of these men and I will always be grateful for all that they did to make the successful completion of this thesis possible.

I would also like to acknowledge the support of my family in Mississauga. Without their support, it would have been difficult to sustain over a year's worth of work on this research project. In a special way, I would like to acknowledge the support of my girlfriend, Caroline Schnurr. She has been extremely supportive and patient with me, especially in the moments when it seemed as though this paper would be a never ending project. Throughout the research project, she was a motivational force whenever I was discouraged or exasperated with the thesis writing process, and I am grateful. In addition to Caroline, my friends in Ottawa and Mississauga have also been a tremendous support to me while writing this paper.

Finally, I would like to acknowledge and thank each of the policy actors and government officials who generously volunteered their time and allowed me to interview them for this thesis. These interviews were my most valuable source of information. It would have been impossible to write this thesis without their willingness to contribute to the research project. Every where I travelled to conduct these interviews, I found a very warm and hospitable welcome, and for that I am grateful. I am also appreciative of the assistance provided by diplomats at the U.S. Embassy and the Embassy of Mexico in Ottawa for helping me arrange research interviews in their respective national capitals.

The untold story of the SPP is really a tribute to the members of the professional civil service and political appointees in all three countries who worked tirelessly in the years after the terrorist attacks of $9 / 11$, to ensure that the citizens of North America could continue to enjoy uninterrupted trade, the benefits of economic growth, and the best quality of life in the world. The development, negotiation, and implementation of the SPP is a tribute to their noble and hard work. I hope that this thesis adequately reflects the accomplishments of their work.

$\sim$ Steven Masson

Ottawa, April 2008 


\section{TABLE OF CONTENTS}

ABSTRACT ii

ACKNOWLEDGEMENTS iii

LIST OF TABLES . $\mathrm{v}$

LIST OF FIGURES .vi

LIST OF ACRONYMS vii

INTRODUCTION .1

Literature Review................................................................................................

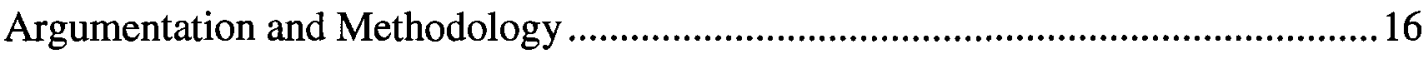

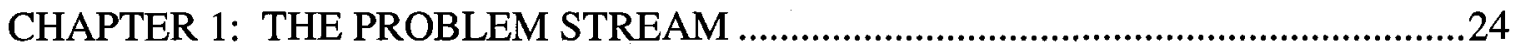

1.1 The Problem Stream in the Multiple Streams Model ..........................................24

1.2 Problem \#1 Improving North American Competitiveness ...................................27

1.3 Problem \#2 The Incomplete NAFTA Agenda ...............................................32

1.4 Problem \#3 The Thickening of America's Borders ..............................................36

1.5 Problem \#4 Accepting Mexico's Place at the North American Table ..................43

1.6 Budget Constraints...............................................................................................48

CHAPTER 2: PRIVATE SECTOR ACTORS IN THE POLICY STREAM....................52

2.1 The Policy Stream in the Multiple Streams Model............................................52

2.2 Policy Alternatives in the Private Sector ...........................................................55

2.3 Private Sector: Softening Up...........................................................................62

\section{CHAPTER 3}

ALTERNATIVE SPECIFICATION IN THE PUBLIC SECTOR ......................................68

3.1 Policy Alternatives in the Public Sector .............................................................68

3.2 Government Sector: Softening Up .................................................................75

3.3 Structuring the NAI Agenda ...............................................................................8

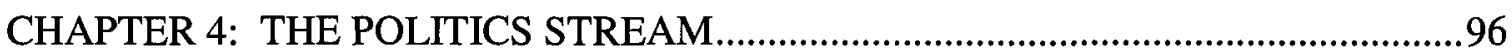

4.1 The Politics Stream in the Multiple Streams Model ..........................................96

4.2 The National Mood ...............................................................................................98

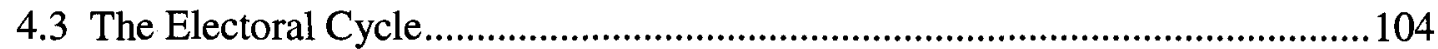

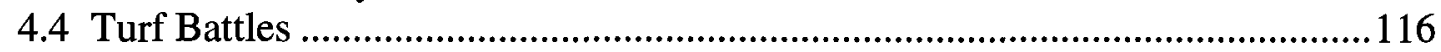

4.5 Balance of Organized Political Forces................................................................119

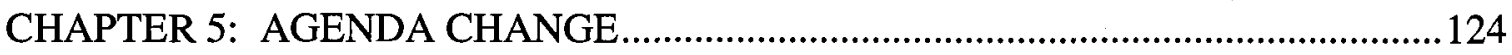

5.1 The Opening of the Policy Window ...........................................................124

5.2 The Policy Entrepreneurs....................................................................................130

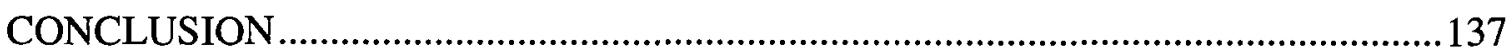

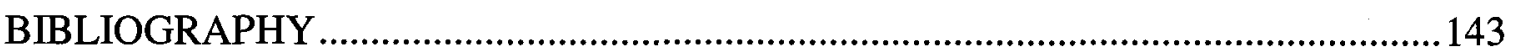




\section{LIST OF TABLES}

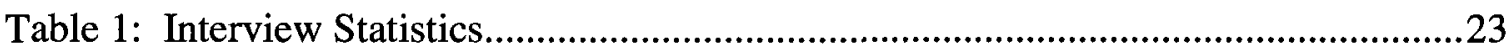

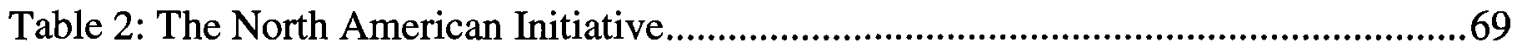




\section{LIST OF FIGURES}

Figure 1:

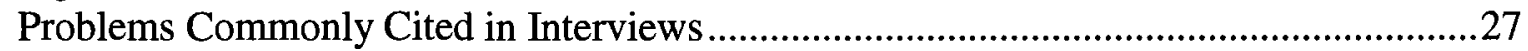

Figure 2: Comparative Real GDP Growth...........................................................28

Figure 3:

FDI flows to Mexican factories located in the northern border region 1996-2003 


\section{LIST OF ACRONYMS}

\begin{tabular}{|l|l|}
\hline CCCE & Canadian Council of Chief Executives \\
\hline CISEN & Centro de Investigación y Seguridad Nacional \\
\hline COC & Council of Canadians \\
\hline DHS & Department of Homeland Security \\
\hline DFAIT & Department of Foreign Affairs and International Trade (Canada) \\
\hline NAFTA & North American Free Trade Agreement \\
\hline NAI & North American Initiative \\
\hline NASPI & North American Security and Prosperity Initiative (CCCE) \\
\hline NPNA & New Partnership in North America \\
\hline NSC & National Security Council \\
\hline OPP & Office of Public Policy (Office of the President, Mexico) \\
\hline P4P & U.S.-Mexico Partnership for Prosperity \\
\hline PCO & Privy Council Office (Canada) \\
\hline PMO & Prime Minister's Office \\
\hline SRE & Secretaría de Relaciones Exteriores (Mexico) \\
\hline TBWG & U.S.-Canada Transportation Border Working Group \\
\hline USTR & United States Trade Representative \\
\hline
\end{tabular}




\section{INTRODUCTION}

On 23 March 2005, Canadian Prime Minister Paul Martin and his Mexican counterpart, Vicente Fox, joined American President George W. Bush in Waco, Texas to launch the Security and Prosperity Partnership of North America (SPP). This occasion constituted the first trilateral meeting of the three leaders to discuss North American issues since their predecessors had gathered in San Antonio on 2 October 1992 to initial the NAFTA Treaty. Over the course of this thirteen year interlude, significant changes had occurred in the social, political and economic spheres of each country. With the added impetus of globalization, the three economies were becoming increasingly integrated. Despite this trend, little attention had been devoted to trilateral coordination beyond the implementation of NAFTA and its two side agreements.

While this state of affairs drew significant criticism from segments of the business and academic community, government officials in the three countries seemed content to rely on bilateral mechanisms for managing relations with their continental partners. A pattern of dual bilateralism - a hub and spoke relationship where emphasis was placed on the management of the Canada-United States and Mexico-United States relationshipappeared to be deeply entrenched and successful. Even after the profound shift that occurred in Mexico with the appearance of its first democratically-elected president on 2 July 2000 , it appeared as though dual bilateralism would continue to supersede any movement towards the addition of new architecture for managing the North American relationship.

During the months that followed 11 September 2001, a serious test arose for the dual bilateral approach to the management of the North American relationship. In the 
aftermath of the devastating terrorist attacks on Lower Manhattan and Pentagon City, it was apparent that the political context in North America had been altered. Security became such an important consideration for officials and politicians in Washington, D.C. that a new framework had to be negotiated in order to ensure that the economic interests of Canada and Mexico could still obtain a hearing in Washington. Canada and Mexico were also forced to revamp their bilateral security cooperation with the U.S. and align it closer to American preferences. All three countries were aware that a new balance had to be struck between security and prosperity; a balance that treated these two objectives as co-dependent and inseparable.

The security-prosperity balance was a message that resonated in Ottawa, Mexico City, and Washington. Through fits and starts, the concept of co-dependency between security and prosperity evolved to become the new paradigm for governing the North American relationship. While this paradigm did not completely eliminate the reliance on dual bilateralism that had become the path of least resistance for all three countries, it did emphasize that the challenges facing North America could no longer be divided neatly between the Canada-U.S. relationship and the U.S.-Mexico relationship. The challenge of maintaining North American security and economic openness required not only a pairing of the concepts of security and prosperity, but also a bridging, wherever possible, of the three bilateral relationships under a single trilateral framework.

The SPP constituted significant policy change for the three countries, insofar as it provided a new architecture for managing the North American relationship. It rested upon two principles. The first was the dictum of trilateral cooperation wherever possible. This was a core principle that underpinned the security-prosperity paradigm, as it recognized that not all problems lent themselves to trilateral resolution and that capacities 
differed across the three countries; in other words, "three could talk but in specific instances, only two could do." This principle accepted that, in discussing the security and trade facilitation initiatives, all three countries should be at the same table, even if only Canada and the United States, or the United States and Mexico, could move ahead on any given issue. This premise belied the second core principle of the new architecture: that it would be limited in scope. That is, the SPP framework was not an absolute re-ordering of North American relations, but rather an incremental and limited process.

The creation of the SPP framework was innovative insofar as it expanded a system of managing relations from the centre of government across a broad slate of policy sectors. The process was designed to work within the realm of what was politically possible in order to forge a trilateral agenda for the continent. Often, it involved forcing progress on existing trilateral and bilateral initiatives through elevating workaday issues to the political level, through reporting requirements tied to scheduled ministerial meetings and leaders' summits. The SPP framework was also the first instance where a structure was created to permit Mexican inclusion on a broad off-the-border trilateral agenda, while recognizing the dynamics of the two distinct bilateral relationships each country pursued with the United States.

The definition of the SPP as creating new architecture is at variance with the theories that dominated public discourse about the SPP. For example, one popular approach is to portray the SPP as step toward deeper integration, laying the groundwork for the eventual development of a common external tariff and security perimeter for North America. An equally pervasive criticism of the SPP is that it is a secretive process designed to erode national sovereignty by conspiring to deepen North American integration by granting privileged access to private sector actors. A third stream of public 
discourse on the SPP centers around the question of whether the SPP is inconsequential and lacking substantive deliverables. These assessments, many of which are found in the media, in the publications of civil society groups, and in academic writing, are indicative of the general lack of understanding that exists about the origins and objectives of the SPP and its implications for the North American relationship. Cognizant of the failure of the three governments to effectively communicate the rationale behind the SPP, this research project was pursued with the objective of providing the first comprehensive analysis of the origins of the Security and Prosperity Partnership. The thesis uses those insights to provide a coherent framework for defining and understanding the SPP as a process-driven initiative, premised on building new architecture, rather than as a contentdriven initiative designed to accelerate North American integration.

\section{Literature Review}

The argument that the SPP was an intentional choice to pursue a process-driven initiative runs contrary to the predominant themes found in the literature. Most scholars who have published on the subject of the SPP have failed to consider it as anything other than the inability of the three governments to produce substantive initiatives to deepen North American integration. They analyzed the SPP as a failed attempt to deliver substantive content, rather than considering the implications of the new architecture it created. These scholars measured the SPP in terms of its content, consistent with the expected outcomes of a security perimeter or customs union, as opposed to measuring the changes it wrought to the architecture of the North American relationship. This inattention to architecture and reluctance to consider a process-driven initiative as an option is a major deficiency in the literature. This deficiency is attributed to the fact that 
most recent publications on North America have focused overwhelmingly on the subject of North American integration.

At the turn of the century, a bold vision for deepening North American integration was presented by American University's Robert Pastor in his seminal work, Towards a North American Community. ${ }^{1}$ Pastor's vision, often compared to an Europeanist approach to integration, advocated the creation of a North American community through the construction of new supra-national institutions. ${ }^{2}$ This argument was premised on the assumption that, at a society-to-society level, a North American identity already existed, that intra-firm trade was expanding across the region, and that the three governments were lagging behind society and the private sector in accepting the emergence of a North American community. This vision really pushed the envelope; it was far more ambitious than any of the proposals found in the literature on North American integration, which has been dominated by two often complementary subjects: the creation of a continental security perimeter and the establishment of a North American customs union. Within this body of literature, the tendency is to treat the SPP in the context of its contribution toward achieving these integrationist objectives.

The idea of creating a common security perimeter for North America has generated a significant amount of attention from scholars in all three countries. ${ }^{3}$

\footnotetext{
${ }^{1}$ Robert Pastor, Toward a North American Community: From the Old World to the New (Washington, DC: Institute for International Economics, 2001).

${ }^{2}$ In particular, Pastor recommends: (1) the creation of a North American Inter-Parliamentary Group; (2) an arms-length North American Commission composed of five independent experts from each country to identify a 'North American agenda' for leaders' level meetings; (3) a North American Investment Fund modeled on the EU Social Cohesion Fund, in order to close the development gap between Mexico and the U.S.; (4) a North American security perimeter; (5) the establishment of North American research centers.

${ }^{3}$ For a balanced collection of essays that address the security challenge from Canadian, Mexican and American perspectives, see Peter Andreas and Thomas J Bierstaker, eds., The Rebordering of North America: Integration and Exclusion in a New Security Context (New York: Routledge, 2003). An analysis of the security perimeter fused with economic considerations is found in Bradly $\mathbf{J}$. Condon and Tapen Sinha, Drawing Lines in the Sand and Snow (Armonk, NY: ME Sharp, 2003). A refreshing and important
} 
Canadian scholars tended to conduct their analysis through the exclusive lens of the

bilateral Canada-U.S. relationship, while American scholars focused attention on the challenges that exist along the U.S.-Mexico border. ${ }^{4}$ The consequence of this divergence in emphasis is that scholars of different countries emphasized different policy solutions, with insufficient attention devoted to assessing how a trilateral framework for a security perimeter could be achieved. It did, however, underscore the different set of political considerations and problems that exist in America's two border relationships.

The scholarship on North American economic integration is characterized by a clash between scholars who promote a customs union and those who argue for a more incremental approach to North American integration. ${ }^{5}$ Almost all of these publications begin from the premise that the North American Free Trade Agreement (NAFTA) is insufficient on its own for fostering economic growth. Accordingly, most scholars were inclined toward advocating substantive content-driven measures as the only policy

contribution to the literature is found in Jordi Díez, ed., Canadian and Mexican Security in the New North America: Challenges and Prospects (Montreal: McGill-Queen's University Press, 2006). This collection of essays provides an assessment of Canadian and Mexican responses to the post 9/11 security environment, in addition to identifying new areas of bilateral cooperation between the two countries. This is a refreshing departure from most Canadian scholarship which focused exclusively on the Canada-U.S. dynamics of security cooperation. For example, see William Dymond and Michael Hart, "Canada and the Global Challenge: Finding a Place to Stand," C.D. Howe Institute, The Border Papers, no. 180 (March 2003). ${ }^{4}$ For example, Canadian military historian J.L. Granatstein argued for an increase in Canadian military spending in order to ensure that Canada maintained its voice on continental security; he expressed the belief that America would proceed unilaterally to build its own security perimeter with or without Canada's support [J.L. Granatstein, "A Friendly Agreement in Advance: Canada-U.S. Defense Relations Past, Present, and Future," C.D. Howe Institute, The Border Papers, no. 166 (June 2002)]. Peter Rekai advocated a security perimeter that includes a common approach to tracking the entry and exit of temporary visitors to the two countries [Peter Rekai, "U.S. and Canadian Immigration Policies: Marching together to Different Tunes," C.D. Howe Institute, The Border Papers, no. 171 (November 2002)].

${ }^{5}$ See Wendy Dobson, "Shaping the Future of North American Economic Space," C.D. Howe Institute, The Border Papers, no. 162 (April 2002); Danielle Goldfarb and William Robson, "Risky Business: U.S. Border Security and the Threat to Canadian Exports ," C.D. Howe Institute, The Border Papers, no. 177 (March 2003); William Dymond and Michael Hart, Common Borders, Shared Destinies: Canada, the United States, and Deepening Integration (Ottawa: Centre for Trade Policy and Law, November 2001). For a U.S. perspective, see Gary Hufbauer and Jeff Schott, "The Prospects for Deeper North American Economic Integration: A US Perspective," C.D. Howe Institute, The Border Papers, no. 195 (January 2004). 
approach for deepening North American economic integration; most of these proposals were accompanied by further ones to deepen continental security cooperation. The most contentious subject in this debate centered on the pace and sequence for pursuing deeper integration, rather than questioning the merits of pursuing a customs union at all.

Some scholars such as Wendy Dobson, William Dymond, Gary Hufbauer, Michael Hart, William Robson and Jeff Schott articulated the need to package customs union-like initiatives together into a big vision that could be presented swiftly to the United States. For example, Dobson promoted the concept of a strategic bargain whereby Canada could offer a pragmatic mix of customs union-like and common market-like proposals combined with new Canadian initiatives in areas of strength that were of particular interest to the Americans, such as natural resources, energy and enhanced security cooperation. ${ }^{6}$ These proposals were designed to attract a political champion in Washington by offering grand sweeping initiatives that could cut across parochial Congressional interests. Other scholars argued that pace and sequencing mattered and that a customs union-like proposal would have to be implemented through incremental steps, such as sectoral customs unions. ${ }^{7}$ A third category of scholars and commentators, such as Robert Wolfe and Sidney Weintraub, rejected the argument that a customs union

\footnotetext{
${ }^{6}$ Wendy Dobson, "Shaping the Future of North American Economic Space," C.D. Howe Institute, The Border Papers, no. 162 (April 2002).

${ }^{7}$ See Danielle Goldfarb, "The Road to a Canada-U.S. Customs Union: Step-by-Step or in a Single Bound?" C.D. Howe Institute, The Border Papers, no. 184 (June 2003); Axel Huelsemeyer, "Toward Deeper North American Integration: A Customs Union?" Canadian-American Public Policy Occasional Paper no. 59 (Canadian-American Centre, University of Maine, October 2004). For example, Danielle Goldfarb emphasized the compatibility of incrementalism with longer term big visions as a way to preserve the momentum behind incremental changes to the North American economic relationship. She contextualized this proposal by making a well reasoned argument for a phased approach to a customs union that would start by harmonizing Most Favoured Nation tariff rates in the sectors in which these rates are similar and unlikely to arouse politically sensitivity.
} 
was necessary for advancing Canadian interests in Washington. ${ }^{8}$ American skeptics of the customs union proposal also emphasized that a big vision for North America could only obtain political buy-in from American politicians if Mexico was included; an argument dismissed by most Canadian scholars.

Absent from this debate on North American integration was any concept of reordering North American relations on the basis of making ongoing cooperation more effective. Whenever the SPP was referenced in this literature, it was framed as a failure to achieve progress toward a customs union or common security perimeter, rather than a distinct process-driven alternative for strengthening North American cooperation. The few scholars who have ventured to analyze the SPP along a separate track from the debate on deepening integration have also tended to subscribe to the notion that the SPP was a failure to produce substantive deliverables that would advance North American integration. Even the writers who reflected on some of the normative or architecturerelated contributions of the SPP do so without making a powerful case for understanding the SPP as a deliberate decision to build new architecture for the continent.

One of the most thorough publications on the SPP is a white paper written for the Hudson Institute by American analyst Chris Sands and University of Alberta political scientist Greg Anderson. The white paper casts a broad net, analyzing the SPP from the

\footnotetext{
${ }^{8}$ Robert Wolfe argued that no new legal text or grand bargain codifying the North American constitution would guarantee Canadians better access to the United States, but rather that this access could only persist if there was sustained and continuous engagement by Canadian officials and lobbyists [Robert Wolfe, "Where's the Beef? Law, Institutions, and the Canada-U.S. Border," in The Art of the State, Vol. II: Thinking North America, eds. Thomas J. Courchene, Donald Savoie, and Daniel Schwanen (IRPP: Montreal, 2004): 69-96]. Sidney Weintraub expressed skepticism with the need to package big ideas together into appealing trade-offs as the only means of obtaining American support. He argued that problems would arise if Mexico was excluded from a customs union. Specifically, he argued that Mexican exclusion would complicate North American unity because the U.S.-Mexico relationship would remain one of free trade, while Canada and the U.S. would have a common external tariff [Sidney Weintraub, "A North American 'Community:' Pros and Cons," Center for Strategic and International Studies, Issues in International Political Economy, no. 62 (January 2005), http://www.csis.org/media/csis/pubs/ issues200501.pdf].
} 
2005 Waco Summit to the 2007 Montebello Summit. Their study is premised on a model that traces the evolution of the SPP by analyzing three separate power relationships: the relationship between the Executive Branch and the Congress, the bargaining asymmetries between the United States and its partners, and the relationship of special interest groups to government actors. ${ }^{9}$ Even though their model is useful for understanding the evolution of the SPP, it reveals little about the policy design that underpinned it. They do not even attempt to apply the concept of power brokerage to explain the origins of the SPP. Their focus on bargaining and power relationships suggests that power imbalances and the exclusion of certain actors from the process resulted in the failure of the SPP to produce substantive results, rather than considering the possibility that the SPP was never designed to produce substantive new content.

Two American scholars, Jason Ackleson and Justin Kastner, also applied the concept of power relationships as the premise for their analysis of the SPP. Ackleson and Kastner used a model of International Political Economy (IPE) to explain the increased role of state power in trade negotiations. ${ }^{10}$ In so doing, they correctly identified the emergence of Executive-level bureaucratic actors as the driving force behind the SPP. They argued that this outcome was consistent with IPE models that posit a significant role for bureaucratic power in driving foreign policy. In contrast to Sands and Anderson, this approach allowed for a more process-driven conception of the SPP to emerge. Specifically, they argued that the SPP created a two-speed framework that conferred the political backing necessary to generate forcing pressure on bureaucrats to deliver results

\footnotetext{
${ }^{9}$ Greg Anderson and Christopher Sands, "Negotiating North America: The Security and Prosperity Partnership," Hudson Institute, White Paper (Fall 2007).

${ }^{10}$ Jason Ackleson and Justin Kastner, "The Security and Prosperity Partnership of North America," The American Review of Canadian Studies 36, no. 2 (Summer 2006): 207-232.
} 
for ongoing initiatives more effectively. Their research also raised questions about the number of local, state, and federal government agencies involved in SPP initiatives and the possibility that this multi-level governance could actually decelerate progress on achieving SPP deliverables.

Canadian political scientist Geoffrey Hale published an article arguing that the SPP was constrained by its ability to produce substantive results because of incomplete political buy-in. ${ }^{11}$ Applying the concept of “intermesticity," Hale uses a version of Robert Putnam's two-level game to analyze the possibilities for deepening North American security cooperation. He contended that domestic politics in Canada, Mexico, and the United States precluded the emergence of a strategic agenda for the SPP, because of the inability to build domestic political consensus at one level of the game. He used this outcome as the premise for characterizing the SPP as the "politics of purposeful incrementalism." It is for this reason, he argued, that SPP architects had to turn to safe ground rather than pursue an ambitious strategic agenda. Accordingly, he views the SPP as inconsequential because it failed to generate large-scale policy change.

With the unique insight of having worked as a political-economic officer at the Mexican Embassy in Washington after 9/11, Marcela Celorio adds practitioner insights to the literature on the SPP. Like Ackleson and Kastner, Celorio emphasized architecture in her analysis of the SPP, albeit through a security-centric lens. ${ }^{12}$ She portrayed the SPP as a limited agreement that advanced cooperation within the existing legislative framework, rather than pursuing a shared trilateral vision. She also argued that government officials

\footnotetext{
${ }^{11}$ Geoffrey E. Hale, "Sharing a Continent: Security, Insecurity, and the Politics of 'Intermesticity,"” Canadian Foreign Policy 12, no. 3 (2005/2006): 31-43.

${ }^{12}$ Marcela Celorio, "The Current Debate Regarding the SPP: Security and the Integration of North America," Center for North American Studies, White Paper (Washington: American University, 2006).
} 
favored an intermediate position, while the private sector was well ahead of the three governments. ${ }^{13}$ Her analysis assessed how the SPP created a new scope for inclusion of the security agenda in discussions on regional integration. Her conclusion was that, by including a security agenda in the framework, the SPP represented an important achievement on the road to creating new mechanisms that reflected North American interdependence. While she provides the clearest iteration of the architecture argument found in the literature, she fails to substantiate her conclusions with any analytical framework or supporting evidence.

Canadian political scientist Stephen Clarkson undertook a completely different approach to analyzing the SPP. Instead of studying the SPP through the interaction of political actors, or through the lens of the bureaucratic model used by Ackleson and Kastner, Clarkson analyzed the normative contribution of the SPP to the existing regime for managing North American relations. ${ }^{14}$ Specifically, he conducted his analysis through the paradigm of constitution-building, identifying the customs and norms that the SPP has contributed to North American relations. He also analyzed the effect of this new normative regime on Canada's room for maneuverability. Clarkon's article is clearly Canadian centric, devoting little attention to the benefits or downsides in terms of maneuverability for the U.S. and Mexico. He concluded that the SPP did give Canada legitimate access and a voice in U.S. Executive Branch departments and agencies.

\footnotetext{
${ }^{13}$ Celorio's research found that the majority of government officials she interviewed did not embrace the concept of deeper integration or the need for new political institutions to forge a North American community. Rather, she found that these officials embraced an 'intermediate position' that recognized the three countries should no longer think in an isolationist manner and that they should work together in policy sectors beyond the commercial scope and start thinking about common economic spaces [Marcela Celorio, "The Current Debate Regarding the SPP: Security and the Integration of North America," 7].

${ }^{14}$ Stephen Clarkson, "Maneuvering Within the Continental Constitution" in Canada Among Nations 2007: What room for Maneuver? eds. Jean Daudelin and Daniel Schwanen (Montreal: McGill-Queen's University Press, 2008): 248-267.
} 
Despite this access, Clarkson argued that Canadians still had to fully accept American security demands, reducing room to pursue distinctly Canadian interests. In other words, for Ottawa to pursue its economic objectives, it had to first satisfy Washington's security agenda.

Written from a nationalist Canadian perspective, the article seized the opportunity to criticize the SPP for creating an opening for an exclusive and privileged role for the private sector in influencing governments. Sands and Anderson also identified the lack of transparency and exclusiveness as the Achilles heel of the SPP. This is also a popular argument of civil society groups who oppose the SPP. ${ }^{15}$ Clarkson's analysis concluded that if any actor benefited from increased access under the SPP framework, it was the Canadian private sector.

Other Canadian scholars assessed the SPP in the context of Canadian sovereignty constraints. This line of argumentation was present in an essay by Canadians Philippe Lagassé and Joel Sokolsky. ${ }^{16}$ Although they excluded consideration of the prosperity pillar of the SPP and the dynamics of the U.S.-Mexico relationship from their analysis, these academics echoed Stephen Clarkson in arguing that Canada had little choice but to subscribe to the American security stance of pursuing a multi-layered security approach. ${ }^{17}$ In contrast to Clarkson, these authors suggested that the SPP and Smart Borders both reflected a Canadian preference for regimes that allowed cooperation without the sovereignty costs that would come from the implementation of a security perimeter. Sokolsky and Lagassé also contended that it was to Canada's advantage to pursue dual

\footnotetext{
${ }^{15}$ For an example of a civil society critique, see Teresa Healy, "Deep Integration in North America: Security and Prosperity for Whom?” Canadian Labour Congress, Research Paper \#42 (20 February 2007). ${ }^{16}$ Philippe Lagassé and Joel L. Sokolsky, "Suspenders and a Belt: Perimeter and Border Security in Canada-U.S. Relations," Canadian Foreign Policy 12, no. 3 (2005/2006): 15-29.

${ }^{17}$ The multi-layered security approach consists of both 'suspenders'-perimeter security in North America and abroad, and 'belt' - a thickening of America's borders with Canada and Mexico [Ibid].
} 
bilateral regimes in the security sphere, since it would force the United States to treat its two borders as distinct by having to negotiate two separate border accords. This article represented yet another example of the Canadian tendency to exclude Mexico from scholarship on the North American relationship.

A very important collection of essays on the subject of North American cooperation was published in International Journal in the summer of 2006. The collection of essays was commissioned to examine the implications for North American politics of the end of the Cold War, the 9/11 terrorist attacks, and the American decision to go to war in Iraq. ${ }^{18}$ Most of the contributors also made reference to the SPP. The position articulated by the journal's guest editors was to describe the SPP as bordering on insignificant in the context of understanding how this new policy environment has bound Canada and Mexico to American security priorities. The guest editors subscribed to the argument that the SPP failed to deliver on larger policy alternatives; they argued that the SPP altered little of substance in the way in which the three countries approached North American security.

The disposition to treat the SPP as a content-driven initiative is picked up in the assessments of most of the scholars reviewed above. While their models provide a coherent framework for analyzing what Sands and Anderson subtly suggest was a far too incremental framework that seized on easily accomplished "early harvest initiatives," it left barely any space for appreciating the architecture created by the SPP. Monica Serrano portrayed the SPP as status quo policies that failed to recognize the

\footnotetext{
${ }^{18}$ Jane Boulden and Monica Serrano, "Guest Editors' Introduction," International Journal 61, no. 3 (Summer 2006), 529.
} 
interdependent relationship between security, trade, and migration. ${ }^{19}$ She argued that new framework should have shifted U.S. policy away from eliminating threats, to an approach that seeks to manage threats. Stephen Clarkson presented the security relationship in North America as reflecting "constrained bilateralism. ${ }^{, 20}$ He argued that the SPP added little to the "dual and skewed bilateralism" that characterized a trilateral relationship dominated by the structural economic power of the United States. He concluded that the SPP was insignificant and that this asymmetrical bilateralism will continue irrespective of the SPP. He also portrayed the SPP as adding little new in terms of trilateral governance, dismissing it as little more than an 'intergovernmental Sears catalogue.' This characterization is emblematic of the widespread belief that permeates the entire body of literature on the subject of North American relations; the belief that the only path forward is through the imminent, or eventual, pursuit of big ideas such as a customs union, security perimeter, or new supra-national institutions.

The dominant theme of the literature was to critique the SPP for its failure to deliver substantive new policies. This made it difficult to detect the references scattered throughout the literature to some of the architectural features of the SPP. A major factor that contributed to obscuring the architectural features of the SPP is that all of the above scholars chose to analyze the SPP from 2005 onwards. Instead of analyzing agenda change, these scholars modeled their analysis on the concepts of power relationships, asymmetry, or accession to the American homeland security regime. These techniques work, and are quite effective in the context of the SPP, if the analysis begins with the

\footnotetext{
${ }^{19}$ Monica Serrano, "Integration and security in North America," International Journal 61, no. 3 (Summer 2006): 611-632.

${ }^{20}$ Stephen Clarkson, "Smart Borders and the Rise of Bilateralism," International Journal 61, no. 3 (Summer 2006): 588-610.
} 
Waco Summit in March 2005. However, the decision to commence the analysis at 2005 reduces any incentive to study the pre-decision phase of the SPP in order to understand why and how the SPP emerged as a policy outcome.

As this thesis will demonstrate, by analyzing the variables that affected the policy design of the SPP framework, a very different outcome emerges. By examining the origins of the SPP, it becomes evident that the trilateral framework is not a public policy failure or a victim of asymmetrical bargaining, or even the consequence of subscribing to the security preferences of an American hegemon. Instead, understanding the origins of the SPP produces a far more optimistic assessment: that the SPP succeeded in creating the architecture that it was intended to establish, with the objective of improving the management of an increasingly complex North American relationship.

The pattern of analyzing the SPP as a failure to deliver substantive results is a consequence of the fact that the origins of the Security and Prosperity Partnership was not explored in the existing scholarship. The major contribution of this thesis will be to recast the debate markedly in the direction of understanding the SPP as a process-driven initiative, rather than as the failure to achieve a content-driven initiative. In so doing, this thesis will provide the analytical and substantive framework missing in Ackleson and Kastner and Celorio's work to explain why the SPP should be understood as adding new architecture to the North American relationship and how that outcome was produced.

In a departure from usual Canadian scholarship on the subject, this thesis will also emphasize the role of Mexico in the context of developing policy options for North America. The analysis will strive to explain Mexican preferences and constraints, with a special emphasis on explaining why the three countries had to pursue a two-speed model for the SPP framework. A sub-theme of the paper will identify the shift in Canadian 
attitudes towards the relationship with Mexico and the growing importance of Mexico in shaping American policy preferences; these themes have not been adequately addressed in either the literature on the SPP or in the broader literature on North American integration. This thesis is also the first time that the multiple streams model of public policy analysis will be used to provide a framework for analyzing the SPP.

\section{$\underline{\text { Argumentation and Methodology }}$}

By analyzing the origins of the SPP through the application of the multiple streams model of public policy, the argument will be made that the SPP was developed with the intentional purpose of creating new architecture to manage the growing interdependencies found in the North American relationship. The adoption of this new architecture at the Waco Summit was an informed decision of the three North American leaders to pursue a process - driven agenda over more substantive and content-driven policy alternatives. The SPP came to occupy a place on the decision agenda for the leaders at Waco, because of the emergence of policy entrepreneurs who joined distinct developments in three separate policy, politics, and problem streams when a window of opportunity opened in Fall 2004. This joining of autonomous streams allowed for a process-driven policy alternative, called the North American Initiative (NAI), to be presented as the solution to a slate of problems that was prominent on the three governments' agendas, agendas that were structured by unique constraints and opportunities created by the prevailing political climate in each country.

The multiple streams model yields the insights necessary to explain this outcome. Through the process of alternative specification, government actors in the three countries committed themselves to a policy alternative, the North American Initiative, which was 
designed to perpetuate and expand the paradigm of managing bilateral and trilateral initiatives from the centre of government. ${ }^{21}$ The model also explains why a processdriven policy alternative emerged on the decision agenda at Waco. This outcome was produced because of the existence of a ready policy option that matched with problems already identified on the government agenda; that matched the budget constraints that existed in the United States and Mexico; that survived tests of public acquiescence and technical feasibility where more content-driven alternatives had failed; and that was acceptable given the prevailing political conditions in all three countries. By understanding the developments that prevailed in three separate streams, it becomes evident that the SPP was specifically designed as a process-driven initiative that created new architecture for North America.

When designing this research project, the imperative was to apply a rigorous model of public policy analysis that could produce a coherent and comprehensive analysis of the policy actors and processes that contributed to the rise of the Security and Prosperity Partnership (SPP) as an action item on the decision agenda of the three national leaders at the Waco Summit. The multiple streams model developed by University of Michigan political scientist John Kingdon was selected as the most suitable framework for structuring this analysis.

\footnotetext{
${ }^{21}$ The North American Initiative (NAI) and SPP are two terms that are used interchangeably in most chapters of this paper. To clarify, the NAI refers to the policy option that was developed between 2002 and 2005. The SPP was the name assigned to this policy option just prior to its announcement at Waco in March 2005. When specific policy work is referenced in the paper, the NAI is referenced. However any references to the SPP in the context of events between 2003 and 2005 should be considered synonymous with the NAI.
} 
The multiple streams analysis is useful for charting the movement of public policy from the policy backburner to the top of a government's agenda. ${ }^{22}$ It examines the predecision stages of public policy: agenda setting and alternative specification. Agenda Setting refers to the process of narrowing the set of potential items that people in and around government pay attention to: it is about sorting out how some issues get attention from policymakers while others are relegated to the policy backburner. ${ }^{23}$ The concept of agenda setting is especially pertinent to chapters 1 and 4. Alternative Specification is about narrowing down possible policy alternatives to the set from which choices are actually made. ${ }^{24}$ The alternative specification process is analyzed in chapters 2 and 3 . This model is unique insofar as it combines elements of random chance while simultaneously permitting the data to be integrated into a cohesive structure. The inherent randomness of the model arises from its reliance on unpredictable processesthe emergence of policy entrepreneurs, the opening of policy windows and the coupling of autonomous streams. It is these three concepts that combine to produce the variable of agenda change.

The Kingdon method identifies three fluid and autonomous streams critical for the development of public policy. The problem stream is restricted to examining the processes that contribute to the rise of problems on the government agenda. In this stream, John Kingdon emphasizes the role of indicators and focusing events for

\footnotetext{
${ }^{22}$ Although the multiple streams model had originally been applied in the context of analyzing health and transportation policy in the United States, the model has successfully been applied by Canadian scholars across a range of domestic and international policy sectors in Canada. See G. Bruce Doern and Brian W. Tomlin, Faith and Fear: the Free Trade Story (Toronto: Stoddart, 1992); Brian W. Tomlin, Norman Hillmer, and Fen Osler Hampson, Canada's International Policies: Agendas, Alternatives, and Politics (Don Mills: Oxford University Press, 2008); Brian W. Tomlin and Michael Hart, "The Emerging Policy Shift in Canada-U.S. Relations," in How Ottawa Spends 2004-2005: Mandate Change and Continuity in the Paul Martin Administration, ed. G. Bruce Doern (Montreal: McGill-Queens University Press, 2004): 46-69. ${ }^{23}$ John W. Kingdon, Agendas, Alternatives, and Public Policies (New York: Longman, 2003), 166.

${ }^{24}$ Kingdon, Agendas, Alternatives, and Public Policies, 166.
} 
generating attention for problems on the government agenda. The second stream, the politics stream, examines the structural impact of political changes on the government agenda. The principal variables in this stream are the ability to build coalitions of political support, shifts in the national mood, interagency turf battles, and turnover in government personnel. These two streams collectively influence the structure of the government agenda.

The third stream, the policy stream, has very little to contribute to the structure of the government agenda. Rather, this stream is important for explaining how consensus emerges within a community of policy specialists around specific policy proposals. It produces a policy alternative that can be linked by a policy entrepreneur to problems and political considerations on the government agenda. When a policy window opens-that is, when a fleeting moment to obtain a serious hearing from decision makers arisesthese entrepreneurs spring into action linking problems to available solutions if propitious political conditions exist. It is this coupling of the streams and identification of policy windows that explains the movement of items in the queue awaiting consideration by decision-makers: it explains how an agenda item suddenly moves into position for final enactment.

Understanding the patterns and randomness inherent to each of these streams is critical for fully grasping the multiple streams model. As Kingdon explains, "It [the model] is structured in the same sense that a river is fluid, but its banks usually restrict its movement. The process cannot flow just anywhere." ${ }^{25}$ The critical contribution of the model for understanding public policy making is that agenda change is not caused by any single factor or even the addition of single factors, but rather from the joint effects of

\footnotetext{
${ }^{25}$ Kingdon, Agendas, Alternatives, and Public Policies, 223.
} 
several factors, of things coming together at the same time, of a combination and blending of factors. ${ }^{26}$ This provides an excellent framework for understanding how and why the SPP emerged as the policy alternative of choice for the three national leaders.

As the interviews progressed, it became increasingly evident that there were multiple and often un-related variables motivating officials in all three countries. Just like the multiple streams model predicts, the story that was gleaned from interviews with SPP policy actors was somewhat disjointed, accidental, and dependent on specific policy actors. The absence of a single and consistent story emerging from these interviews confirms the belief that a fairly random model that allows for concurrent, though initially un-related occurrences is very relevant and applicable to the SPP context.

The multiple streams model was valuable for structuring the analysis of public policy making. The organization of this thesis is such that each chapter is designed to analyze a specific stream of the multiple streams model. The existence of three streams was also helpful for sifting through the research data and categorizing it. It set the boundaries to determine how the research data would be organized in each chapter. Once the data was slotted into its specific stream, it could be mobilized as variables for explaining the opening of policy windows, the coupling process, and the eventual emergence of policy entrepreneurs driving agenda change. The existence of specific variables unique to each stream also helped determine how to integrate data once it had been categorized into its proper stream.

The selection of the multiple streams model suited the overall design of the research project. More traditional models of public policy are iterative, starting with problem definition, alternative specification, decision-making, implementation, and

\footnotetext{
${ }^{26}$ Kingdon, Agendas, Alternatives, and Public Policies, 179.
} 
evaluation. ${ }^{27}$ The multiple streams model does incorporate problem definition and alternative specification, though in a concurrent rather than iterative fashion. This worked well for the SPP, since there were multiple and concurrent problems that were not necessarily related. For example, the unfinished business of NAFTA was not directly connected to the trade facilitation complications caused by a thickening of America's borders; however, both were key problems identified by policymakers in and around government in the three countries. It is difficult to envision how an iterative model would have been able to analyze both problems simultaneously. For the purposes of this analysis, implementation and evaluation are not necessarily important considerations, as the scope of this research project is confined to explaining the origins of the SPP. An analysis of how the SPP framework was implemented or evaluated would reveal little about why the SPP ascended on the decision agenda of the three countries.

The new and original content presented in this paper was collected through a four month period of personal interviews with SPP policy actors. The multiple streams model lends itself to a reliance on interviews with policy actors as a method for collecting research data. In fact, this was the data collection method employed by Kingdon himself. This reliance on interviews was especially useful for capturing the varying interpretation of events, problems, policy alternatives, and political circumstances encountered by policy actors responsible for the SPP. It would have been impossible to capture these differing perceptions based solely on the limited body of literature that exists on the SPP.

${ }^{27}$ A very general and simple model of the policy cycle consists of an agenda-setting stage, a period of policy formulation, followed by the decision-making, policy implementation, and policy evaluation stages. The final stage, policy evaluation, may feed into the re-conceptualization of policy problems and solutions [Michael Howlett and M. Ramesh, Studying Public Policy: Policy Cycles and Policy Subsystems, $2^{\text {nd }}$ ed., (Toronto: Oxford University Press, 2003), 13]. While the multiple streams model certainly incorporates most of these stages, the model does not proceed in a sequential manner, since it is restricted to analyzing the pre-decision stage. Rather elements of the policy cycle are mostly found in the variables of each stream, as opposed to being analyzed as separate stages of the policy process. 
Since the multiple streams model provides a structure for analyzing fluid and concurrent changes across different streams of analysis, the policy actors who were forced to confront and respond to these fast-changing events are much better placed to contextualize developments, as opposed to relying on static and limited data available in official press releases, media reports, and official SPP publications. These sources were useful for the purposes of comparing the communications strategy to the explanatory variables fleshed out in the multiple streams model. However, dependence on these primary and secondary sources would have stripped away a layer of detail and nuance that could only be communicated directly by the policy actors involved with designing the SPP. One difficulty in presenting the research data from these interviews is that the identity of interviewees must remain confidential. This decision was made in conformity with guidelines established by the Ethics Committee at Carleton University. Anonymity was especially important in order to ensure forthright interview responses, as a vast majority of interviewees are senior government officials who would only comment on the condition of anonymity. ${ }^{28}$ No individual was interviewed on more than one occasion. ${ }^{29}$ The actual interviews were conducted in Ottawa, Toronto, Mexico City, and Washington DC over six months between July and December $2007 .{ }^{30}$ In total, thirty six

\footnotetext{
${ }^{28}$ In those instances where interviewees were willing to have their names placed on the record, it was felt that doing so could jeopardize the identity of those who expressed a preference for remaining anonymous. Accordingly, the decision was made to maintain complete confidentiality for all interviewees.

${ }^{29}$ In order to distinguish one interviewee from another, careful attention ought to be paid to the date of the interview. For example, there were 7 separate individuals interviewed from the PCO. Although the naming convention appears identical, these interviews can be distinguished according to the date of the interview. ${ }^{30}$ A rigorous methodology was employed to ensure the integrity of the data. A detailed interview methodology was submitted to Carleton University's Ethics Committee. The Committee reviewed the methodology and conferred its approval. One pertinent feature of this methodology was that interviewees were asked to review and sign-off on a transcript of their interview. This process was designed to act as a safeguard against erroneously reporting or interpreting the comments of the interviewees. Inevitably, some interviewees elected not to review the transcript of their interview. While each interviewee received an electronic copy of their interview transcript, only one-third elected to submit revisions.
} 
individuals were interviewed; each interview averaged about one hour. ${ }^{31}$ As indicated in

Table 1, the majority of interviews were with government officials in the three countries;

the interviewees included a mix of Cabinet-level officials, senior civil servants, and

working level officials. The second largest category of interviewees came from the

business community; they spoke on behalf of each country's North American

Competitiveness Council secretariats. ${ }^{32}$ These officials were selected for interviews

because of their intimate knowledge of the organization of the NACC and the interests of

the business communities in each country. The most difficult groups to interview were

civil society organizations. ${ }^{33}$ That being said, civil society groups became involved with

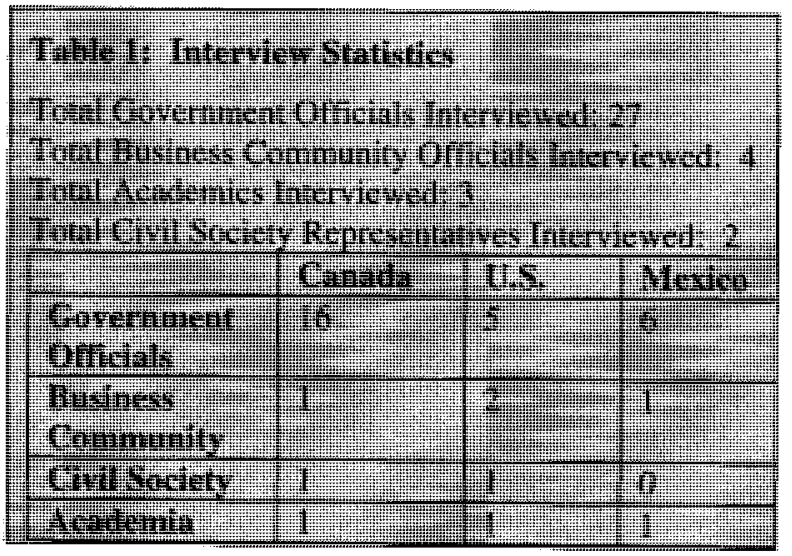

the SPP after its inception, so there was

very little that they could contribute to the

analysis of the origins of the SPP from

interviews with civil society actors. The

following chapters will apply the data

obtained from these interviews to analyze

how the agenda setting and alternative specification process permitted the emergence of

the SPP on the decision agenda of the three North American leaders at the Waco Summit.

\footnotetext{
${ }^{31}$ The selection of interviewees was a carefully managed undertaking. Caution was taken to ensure that that a cross-section of relevant policy actors was interviewed for the research. The assistance of my thesis advisor, Dr. Peter Boehm, was invaluable for identifying interviewees. As Assistant Deputy Minister for North America, he was well situated to identify the leading policy actors in Ottawa, Washington, and Mexico City. I also benefited from the assistance of diplomats at the Embassy of Mexico and the Embassy of the United States in Ottawa to identify interviewees in Washington and Mexico City. Finally, I identified several academics and private sector officials whom I felt could add additional insights. ${ }^{32}$ Officers of all four NACC secretariats were interviewed: Canadian Council of Chief Executives, U.S. Chamber of Commerce, Council of the Americas, and the Instituto Mexicano para la Competitividad. ${ }^{33}$ I compensated for the scarcity of interviews with civil society groups by attending an October 2007 meeting of the Trade and Investment Research Policy Network (a group that includes the Public Service Alliance of Canada, the Canadian Labour Congress, the Canadian Centre for Policy Alternatives, Common Frontiers, and the Canadian Auto Workers' Union). This experience certainly contributed to my understanding of the political role exercised by civil society actors with respect to the evolution of the SPP.
} 
The organization of the following chapters is structured on the basis of the multiple streams model. Chapter 1 explores the problem stream, highlighting four specific problems that garnered attention on the governments' agendas. Chapters 2 and 3 analyze the policy stream, exploring how the NAI model became the favored policy option over competing visions for the future of North America. Chapter 4 assesses the politics stream, providing an analysis of how changing political circumstances structured the three governments' agendas. Chapter 5 will bring the three streams together by identifying the opening of the window of opportunity and the entrepreneurial activity that brought these three streams together to produce agenda change. The conclusion will briefly identify the strategic implications that arise from understanding the SPP as new architecture for organizing North American relations. 


\section{CHAPTER 1: THE PROBLEM STREAM}

In the post $9 / 11$ period several problems rose to prominence on the government agendas of all three countries. The most commonly cited problems by policy actors in and around government were: the challenge of improving North American competitiveness, the incomplete NAFTA agenda, the threat posed by a thickening of U.S. borders, and the need for Canada to accept Mexico's place at the North American table. None of these problems was necessarily new, but the terrorist attacks of 11 September 2001 were a very powerful event that elevated these problems on the government agenda. Through applying the framework provided by the problem stream of the multiple streams model, this chapter will assess why these problems garnered sustained attention on the government agenda during the years preceding the announcement of the SPP.

\subsection{The Problem Stream in the Multiple Streams Model}

The variables that underpin the problem stream explain how certain problems attract attention from policy actors, thereby contributing to the agenda setting process in each country. The prime drivers for explaining the resilience of these problems on the government agenda are indicators, focusing events, and program feedback. Indicators are useful for identifying routine workaday issues that require a response from policymakers. ${ }^{34}$ In contrast, feedback can come from formal program evaluations, from the civil service, or from constituent or user complaints. One common example of program feedback is complaints from civil servants about spiralling cost over-runs or difficulties implementing the program. ${ }^{35}$ On their own, indicators and program feedback

\footnotetext{
${ }^{34}$ Kingdon, Agendas, Alternatives, and Public Policies, 93.

${ }^{35}$ Kingdon, Agendas, Alternatives, and Public Policies, 100-101.
} 
are often insufficient for drawing the attention of policy makers to a problem. These problems often need to be amplified by a focusing event. Although many of these issues had been percolating along the government agenda for years, the terrorist attacks of 11 September 2001 crystallized these problems; they were given a new sense of urgency, and accordingly much greater attention from central agency officials.

The 9/11 terrorist attacks forced these four problems to the top of the government agenda. The American response of hardening its border defences not only endangered the open market access created under the North American Free Trade Agreement, but also forced both Canada and Mexico to reconsider the approach they took to engaging the United States on issues of common security. Perhaps the best measure of the power of 9/11 as a focusing event was that it required direct central agency management for security and trade issues that would normally be the purview of line departments. Central agency involvement, in turn, automatically accorded these problems the highest priority on the government agenda. The magnitude of the focusing event was such that initial policy responses-the Smart Border Accord and the Alianza para la Frontera-were insufficient on their own to resolve the problems identified in this chapter. ${ }^{36}$ Rather, a trilateral response had to be fashioned to create a longer run framework for managing the

\footnotetext{
${ }^{36}$ The Smart Border Declaration was a philosophical centerpiece of thirty initiatives clustered in four policy sectors: customs, immigration, law enforcement, and transportation infrastructure. Smart Borders was an umbrella framework that encompassed ongoing border programs against a new security overlay. It was managed from the centre of government between the PCO and the White House Office of Homeland Security [Confidential interview with a former official with the Privy Council Office, dated 2007-09-06]. Like Smart Borders, the Alianza para la Frontera re-packaged existing trusted traveler programs established by the two governments against a security overlay. However, the Alianza was much more limited in scope than Smart Borders. Its 22 point action plan was concentrated in three core areas: secure flow of people, secure flow of goods, and infrastructure [United States, Department of Homeland Security, "The Mexico-U.S. Border Partnership: Progress Report 2002-2004," 17 January 2005, http://www.dhs.gov/ xlibrary/assets/2004_US-Mex_Book.pdf].
} 
problems that had suddenly come into sharper focus as a result of $9 / 11$; nothing short of the creation of new architecture for North America would suffice.

In addition to prime drivers, the multiple streams model also yields a secondary set of drivers - the re-enforcing drivers - that influence the effect of indicators, program feedback and the focusing event. The most pertinent of the secondary drivers for the analysis here is the budget process of each country. In the multiple streams model, the budget process is described as both a promoter and a constraint. ${ }^{37}$ As a promoter, the budget can push certain items higher on the government agenda. In Canada, the budget acted as a promoter, while in the United States and Mexico, the budget was a significant constraint. The contrasting budget impact across the three countries was a serious constraint on the pursuit of content-driven initiatives that would require new funding. Instead, it encouraged officials to consider a resource neutral alternative by creating new architecture that was capable of improving the effectiveness of existing bilateral and trilateral initiatives.

The research interviews that were conducted for this thesis produced some interesting insights into the problems that preoccupied policy actors in and around government between 2002 and 2005 (see Figure 1). An analysis of interview responses from policy actors interviewed across all three countries yielded four commonly identified problems: the challenge of improving North American competitiveness, the incomplete NAFTA agenda, the Canadian and Mexican fear of a thickening of the United

${ }^{37}$ Kingdon, Agendas, Alternatives, and Public Policies, 107-108. 
States' borders, and the need for Canada to accept Mexico's place at the North American table. $^{38}$

\section{Figure 1: Problems Commonly Cited in Interviews ${ }^{39}$}

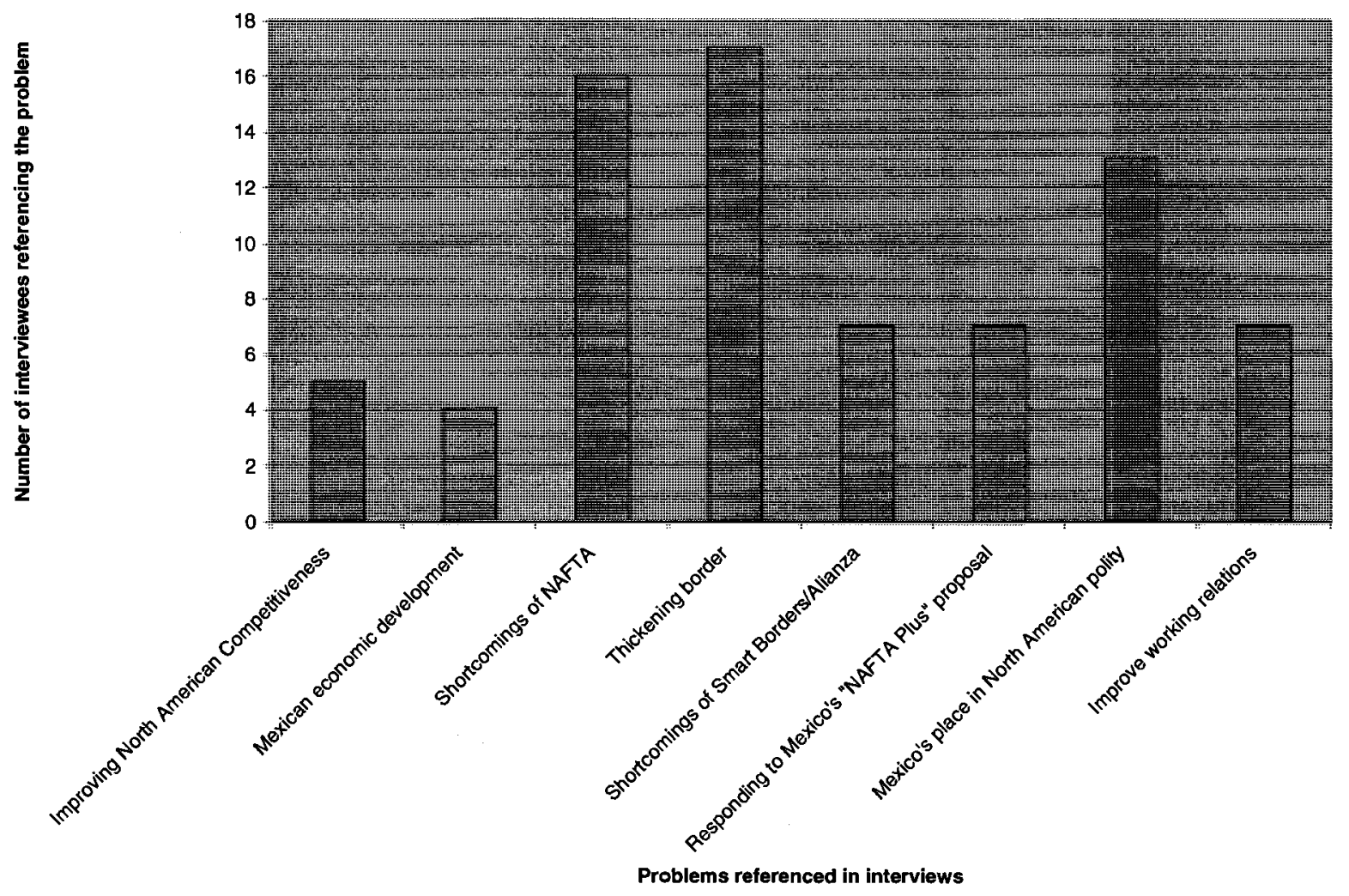

\subsection{Problem \#1 Improving North American Competitiveness}

One problem that attracted a significant amount of attention from policy actors

across all three countries was the growing concern about the competitiveness of North

\footnotetext{
${ }^{38}$ The four problems analyzed here were by no means the only ones identified by policy actors during interviews conducted for this thesis. For example, some policy actors spoke of the problem of a lack of relationship building at the working level between officials in all three countries. Other actors focused on the problems created by the politicization of homeland security in Washington and its effect in altering the bilateral relationship of the U.S. with Canada and Mexico. There were also important problems that remained on a different track, such as the migration issue between the United States and Mexico.

${ }^{39}$ This chart is based on an unscientific tally of how often a given problem was referenced during research interviews. Certain problems that scored higher than North American competitiveness, such as the shortcomings of Smart Borders and the Alianza para la Frontera and the need to respond to Mexico's "NAFTA Plus" were included under the "The thickening of America's borders" problem. The Mexican economic development challenge and the need to improve working relations are addressed under the "Incomplete NAFTA agenda problem."
} 
America as a region. This concern was motivated by the rapid growth of regional economic powers such as China and India. Measured through annual GDP growth rates, the trends were apparent (see Figure 2). Aside from the GDP figures, there were many other indicators available to policy makers that reflected the growing concern of the business community about North American competitiveness. For example, long-term

Figure 2: Comparative Real GDP Growth

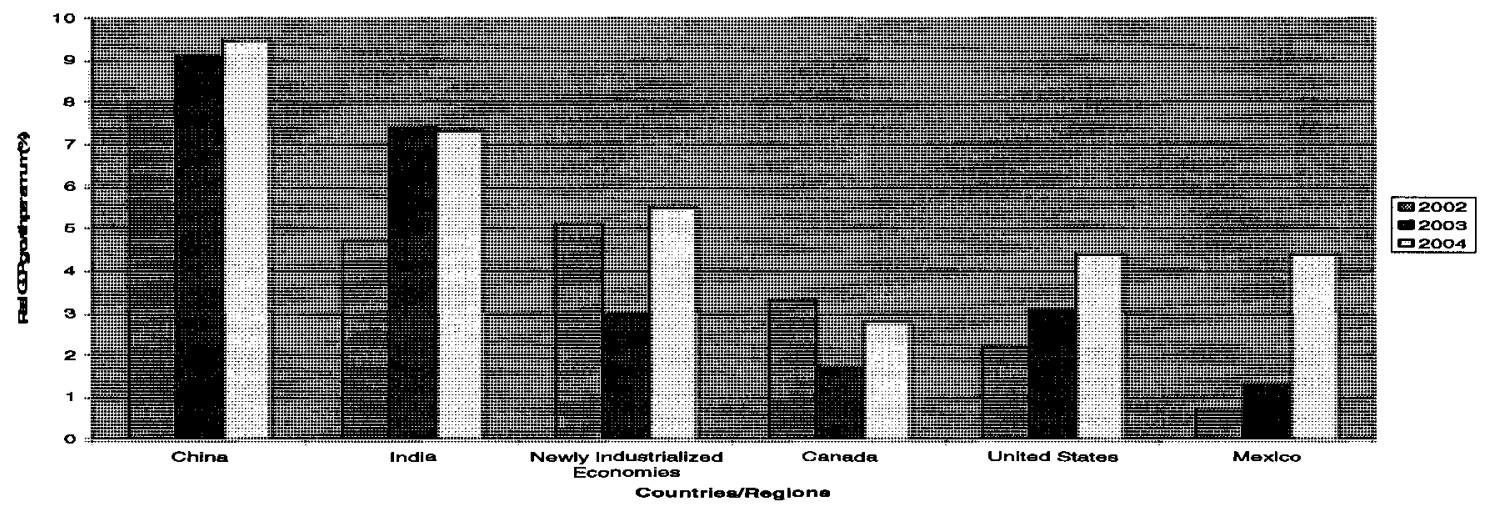

[The data for 2002 and 2003 was obtained from: International Monetary Fund, World Economic OutlookAdvancing Structural Reforms, (Washington: IMF, April 2004), pp. 10; 30. The data for 2004 was obtained from: International Monetary Fund, World Economic Outlook-Globalization and External Imbalances, (Washington: IMF, April 2005), pp. 20; 33; 36].

capital flows-foreign direct investment (FDI)-became increasingly concentrated in China and India. ${ }^{40}$ This reflected the trend toward building global supply chains, with production moving to low-cost countries and technological change reducing transportation costs from offshore production sites.

China's accession to the World Trade Organization in 2001 presented a special problem for Mexico: not only did China cut into Mexico's low-cost market, but Mexico had counted on receiving a continuous flow of FDI from Canadian and American firms

\footnotetext{
${ }^{40}$ In 2003, China was the world's largest recipient of FDI after Luxembourg, with inflows of US\$53.5 billion driven by cross-border mergers and acquisitions. For the same year, FDI inflows to India increased by $24 \%$ [United Nations Committee on Trade and Development, "Regional FDI Trends: A Mixed Picture." Chapter 2, World Investment Report 2004, http://www.unctad.org/en/docs/wir2004ch2_en.pdf].
} 
looking to construct North American supply chains. ${ }^{41}$ In fact, between December 2000 and April 2004, Mexican factories located in the U.S.-Mexico border region witnessed a decline of over one third in the level of its FDI inflows, resulting in over 220,000 lost jobs in some of Mexico's most important export sectors, such as clothing, textiles and electric and electronic equipment (see Figure 3). ${ }^{42}$ While the 2001 economic downturn in the U.S. economy was the trigger for these declines, competition from China and East Asia was fierce; economists speculated that a significant percentage of this long-term capital was re-located to East Asia. ${ }^{43}$ This sudden loss of new investment capital that Mexico had expected to receive when it signed NAFTA, constituted a serious problem for policy actors in Mexico City.

Mexican officials were convinced that NAFTA had given North America a competitive advantage and credited NAFTA with transforming the region into the fastest growing trade bloc in the world. Yet these same officials grew increasingly concerned by

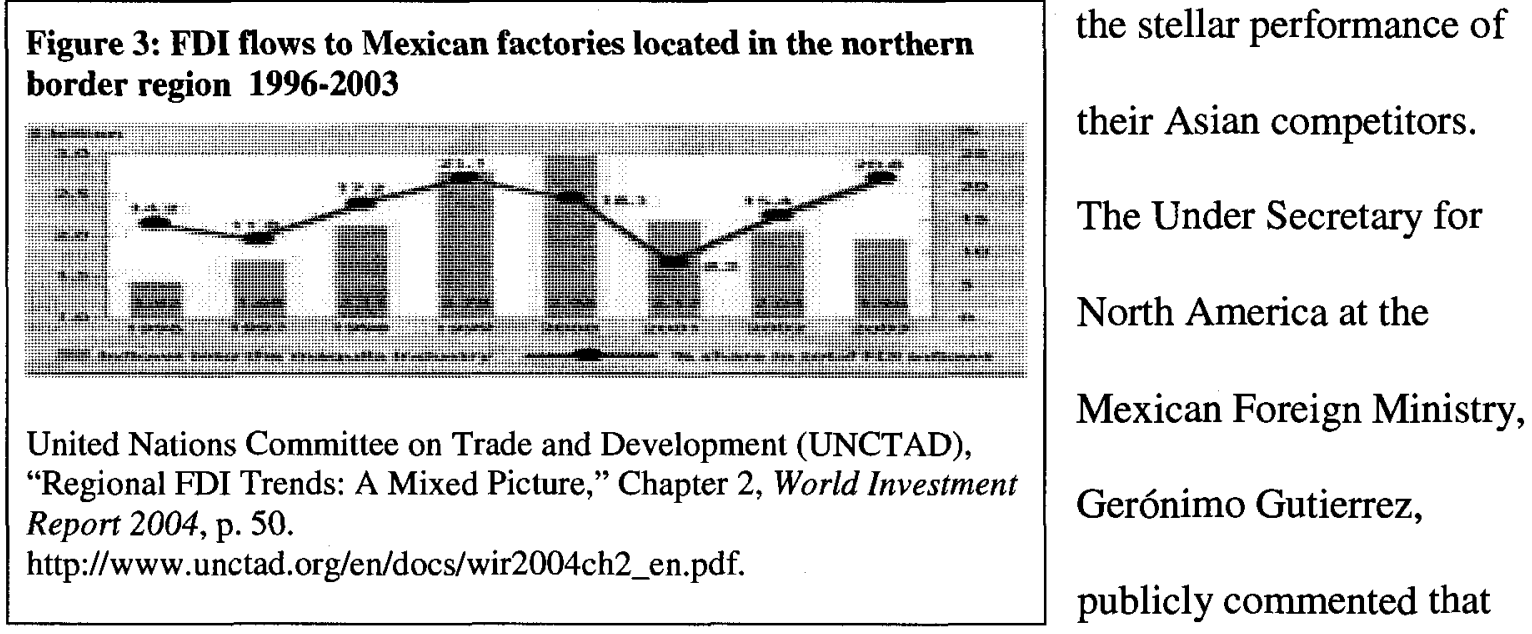

${ }^{41}$ Confidential interview with an official at the Instituto Mexicano para la Competitividad, dated 2007-0926.

${ }^{42}$ United Nations Committee on Trade and Development, "Regional FDI Trends: A Mixed Picture." Chapter 2. World Investment Report 2004, 61. http://www.unctad.org/en/docs/wir2004ch2_en.pdf. ${ }^{43}$ Ibid. 
Mexico's traditional access to the American market was being eroded by competition from the Asian economies. ${ }^{44}$ His boss, Foreign Minister Luis Derbez, identified the need for a new North American initiative to preserve North American competitiveness. ${ }^{45}$ Officials in President Fox's Office of Public Policy were convinced that the North American countries had to close ranks if the continent was to remain competitive against the rising Asian economies. ${ }^{46}$ Of all three countries, Mexico had the greatest economic interest at stake in pursuing an initiative that could restore North America's competitive advantage and reverse the outflow of foreign direct investment from Mexico.

The challenge for Canada and the United States was different. At a time when the North American economy was becoming increasingly dependent on its service sector, there were indications of increasing competitive pressure from China and India. For example, a January 2005 study published by the Federal Reserve Bank of Cleveland observed that the highly educated English speaking graduates of India were drawing certain information-technology jobs away from the United States. ${ }^{47}$ Another worrisome indicator was the growing dependence of the American economy on East Asian imports. China had become the largest exporter of toys, footwear, consumer electronics, and sportswear to the United States. In 2003, China surpassed Mexico to become the second largest supplier of imports to the U.S. ${ }^{48}$ China's competitive pricing also had the

\footnotetext{
${ }^{44}$ Gerónimo Gutierrez, "America del Norte Retos y Proximo Pasos," Instituto Mexicano para la Competitividad (2005), http://www.imco.org.mx/ar43.php.

${ }^{45}$ Luis Derbez, "Competitividad y Diplomacia," Instituto Mexicano para la Competitividad, http://www.imco.org.mx/ar40.php.

${ }^{46}$ Confidential interview with an official at Secretaría de Economía, dated 2007-09-28. The Office of Public Policy performed a central agency planning and coordination function for the economic portfolio of Cabinet departments and agencies in Mexico City. The OPP was led by Dr. Eduardo Sojo.

${ }^{47}$ Catherine L. Mann, "This is Bangalore Calling: Hang up or Speed Dial?" Federal Reserve Bank of Cleveland (15 January 2005), http://www.iie.com/publications/papers/mann0105.pdf

${ }^{48}$ Peterson Institute for International Economics, "Testimony of Nicholas R. Lardy, Committee on International Relations, House of Representatives, 21 October 2003," http://www.iie.com/publications/ papers/paper.cfm?ResearchID=268.
} 
potential to dislocate Canada from its privileged position in the American marketplace; it would likely be only a matter of time before China surpassed Canada as the primary exporter to the U.S.

The United States continued to struggle with the vulnerability created by its dependence on trade with China. Americans were aware that the country had to decrease its dependence on Chinese imports yet consumers persisted in purchasing ever increasing amounts of Chinese imports and the current account deficit-a measure of America's net foreign debt—continued to rise. An important method of reducing American dependency was to transform the North American region into a more competitive export platform.

The challenge of improving North American competitiveness registered with policy actors. Canadian officials knew that North American competitiveness had to be strengthened in order to preserve its own market and access to third country markets. ${ }^{49}$ There was a growing sense in the Cabinet of Prime Minister Paul Martin that events in the global economy were overtaking NAFTA's benefits; the Cabinet was receptive to discussions on moving to a new level of engagement with the United States, though the Cabinet was unwilling to consider re-opening NAFTA. ${ }^{50}$ The business communities in Canada and the United States were also active in raising awareness about the competitiveness issue. Over the past decade, many American multinational firms had restructured their branch plant operations in Canada away from servicing the Canadian market, to developing continental and global production strategies. ${ }^{51}$ The auto sector

\footnotetext{
${ }^{49}$ Confidential interview with a former official at the Privy Council Office, dated 2007-08-14.

${ }^{50}$ Confidential interview with a former Canadian Parliamentarian, dated 2007-09-04.

${ }^{51}$ Stephen Clarkson, "The View from the Attic: Toward a Gated Continental Community?" in The Rebordering of North America, eds. Peter Andreas and Thomas J. Biersteker (New York: Routledge, 2003), 85.
} 
alone accounted for forty percent of intra-NAFTA trade. ${ }^{52}$ The Canadian Council of Chief Executives was among the first to emphasize the competitiveness problem. ${ }^{53}$ In the United States, the Council of the Americas argued that if North American integration ended with NAFTA, the region would find itself at a competitive disadvantage with China. ${ }^{54}$ The involvement of the business community reinforced the inclination of policy actors to focus attention on this growing problem.

\subsection{Problem \#2 The Incomplete NAFTA Agenda}

In 2004 , the ten year anniversary of NAFTA focused attention on the perceived shortcomings of NAFTA. There was a growing sense in all three countries that the NAFTA agenda was incomplete. This was signalled by North American trade ministers in a communiqué released after their 2004 meeting in San Antonio: "We cannot, however, rest on past accomplishments. We are committed to deepening North American integration by building on the NAFTA." ${ }^{, 55}$ The ministers' list of incomplete agenda items included off-the border measures on business facilitation, manufacturing, services, elimination of technical barriers, compatibility of standards, and the need for another round of rules of origin liberalization. ${ }^{56}$ It had also become increasingly apparent to officials at Canada's Department of Foreign Affairs and International Trade (DFAIT) and the U.S. Commerce Department that the NAFTA working groups and committees were in

${ }_{52}$ Pastor, Toward a North American Community, 73.

${ }^{53}$ The co-dependency of security and prosperity was the centerpiece of the CCCE's post $9 / 11$ policy proposa1: the North American Security and Prosperity Initiative. See Canadian Council of Chief Executives, Security and Prosperity Toward a New Canada-United States Partnership in North America (Ottawa: January 2003).

${ }^{54}$ Council of the Americas, A Compact for North America: A Strategy for Building Competitiveness within North America (April 2005), http://www.as-coa.org/files/PDF/pub_151_92.pdf.

${ }_{55}$ Office of the United States Trade Representative, "NAFTA Free Trade Commission Joint Statement-A Decade of Achievement," (San Antonio: 16 July 2004), http://www.ustr.gov/Document_Library/ Press_Releases/2004/July/NAFTA_Free_Trade_Commission_Joint_Statement_A_Decade_of_Achievement.html. ${ }^{56} \mathrm{Ibid}$. 
desperate need of reinvigoration. Canadian officials in particular were concerned that many of these working groups were spinning their wheels. ${ }^{57}$ The need for a new trilateral framework to re-invigorate the NAFTA working groups and committees was evident.

The NAFTA working groups and committees were composed of civil servants from the three countries who were tasked with monitoring and promoting the successful implementation of specific chapters in the NAFTA ${ }^{58}$ Some NAFTA working groups were not meeting at all, while other working groups had come to a standstill on certain issues or diverted their attention specifically towards the implementation aspects of the agenda. For example, the working group on standards related measures had not met for some period of time prior to the SPP. ${ }^{59}$ While working group members had the mandate to proceed with the negotiations on regulations and standards, it was not the sort of work that mid-level civil servants would commit to on their own accord, without guidance from their political masters. ${ }^{60}$ The decision to include a regulatory cooperation framework in the SPP work plan provided the catalyst for action from that working group. ${ }^{61}$

The NAFTA Working Group on Rules of Origin also generated poor program feedback insofar as it was slow to make progress on its mandate to liberalize some of NAFTA's product-specific rules of origin regulations. The private sector was especially vocal in demanding faster progress on reducing the rules of origin burden, as it was estimated that these rules imposed an additional administrative cost on business of

\footnotetext{
${ }^{57}$ Confidential interview with a former official at the Privy Council Office, dated 2007-08-14.

${ }^{58}$ Stephen Clarkson, Sarah Davidson Ladly, and Carleton Thorne, "De-institutionalizing North America: NAFTA's committees and working groups," Third EnviReform Conference (8 November 2002), http://www.envireform.utoronto.ca/conference/nov2002/clarkson-paper2.pdf.

${ }^{59}$ Confidential interview with a U.S. Government Official, dated 2007-12-14.

${ }^{60}$ Anderson and Sands, Negotiating North America, 18.

${ }^{61}$ One early success of the SPP framework was that the U.S. Commerce Department was able to re-generate progress on this issue when it organized a 2006 symposium that brought together central agency officials as well as officials from the regulatory and trade agencies for the first time to discuss regulatory cooperation [Confidential interview with a U.S. Government Official, dated 2007-12-14].
} 
between one percent and five percent of the value of the goods shipped, prompting many North American firms to export under Most Favored Nation rates, as opposed to the NAFTA rate. ${ }^{62}$ In its 2005 report, the Council on Foreign Relations' Independent Task Force on the Future of North America cited unwieldy rules of origin as a problem in need of resolution. ${ }^{63}$ The Rules of Origin working group was considered by one PCO official as the classic example of the inertia that often frustrated Canadian central agency officials. As he explained, the working group consisted of the same officials in each country who had been working together for many years, had an ongoing agenda, and dealt with a highly technical subject. The group was comfortable in its ways and it was a challenge to force it, and likeminded groups, to work harder. ${ }^{64}$ The hope was that a new framework agreement for North America with specific deliverables pertaining to the outstanding items on NAFTA working group agendas, and deadlines for reporting to ministers and leaders, would generate momentum to propel the project forward. ${ }^{65}$ While officials working at Presidencia in Mexico City likely shared these concerns, they had a different interest related to the incomplete NAFTA agenda. They tended to view the issue more through the prism of the need to construct a cooperation chapter under NAFTA. Specifically, Mexico was keen to pursue a strategy of issue linkage: offering enhanced security cooperation with the United States in exchange for improved border infrastructure, a migration accord, and the creation of a North American Investment Fund to attract more investment to underdeveloped regions of the country. ${ }^{66}$

\footnotetext{
${ }^{62}$ See John Manley, “The future of North America," International Journal 60, no. 2 (2005): 497-508.

${ }^{63}$ Independent Taskforce on the Future of North America, Building a North American Community, (New York: Council on Foreign Relations, May 2005), 21.

${ }^{64}$ Confidential interview with a former official at the Privy Council Office, dated 2007-10-03.

${ }^{65}$ Confidential interview with a former official at the Privy Council Office, dated 2007-08-14.

${ }^{66}$ Athanasias Hristoulas, "Trading Places: Canada, Mexico, and North American Security," in The Rebordering of North America, eds. Peter Andreas and Thomas J. Biersteker, 39-40.
} 
In 2004, Mexico's Undersecretary of State for North America reflected on Mexico's priorities for the future of NAFTA. He commented that Mexico's interests were threefold: to enhance the job creating capacity of NAFTA through new mechanisms such as regulatory cooperation; to strike a balance between security and trade facilitation; and to establish mechanisms to provide legal, orderly, and secure migration between countries. ${ }^{67}$ The addition of a cooperation chapter to the NAFTA agreement would benefit Mexico's interests in all of these areas.

Mexican officials perceived the addition of a cooperation chapter to free trade agreements as a reasonable request. After all, most free trade agreements signed by Mexico, such as the one it signed with the European Union, included a cooperation chapter. ${ }^{68}$ The cooperation chapter was envisioned to provide an ongoing agenda of initiatives in policy sectors beyond the realm of the commercial sphere. ${ }^{69}$ For Mexican diplomats, the SPP was considered to be an initial step toward the larger goal of building a cooperation chapter for NAFTA. ${ }^{70}$ These proposals first put forward by President Fox for a "NAFTA-Plus" created a separate problem for government officials in Canada and the United States. Since the proposal was politically untenable, a work-around had to be found. The SPP framework emerged as a compromise. The deliverables and reporting requirements addressed the need to re-energize many of the NAFTA working groups and committees. The contents of the SPP prosperity pillar satisfied Vicente Fox's wishes for

\footnotetext{
${ }^{67}$ Institute for Research on Public Policy (IRPP), "Remarks by the Under Secretary for North America, Gerónimo Gutierrez, at the Conference: North American Integration: Migration, Trade and Security," (Ottawa: IRPP, 2 April 2004), http://www.irpp.org/events/.

${ }_{68}^{6}$ Confidential interview with an official at Secretaría de Economía, dated 2007-09-28.

${ }^{69}$ This cooperation agenda could have included any number of policy sectors where Mexico would have benefited from the expertise and best practices of its North American partners, such as health, the environment, education, or science and technology partnerships.

${ }^{70}$ Confidential interview with an official at Secretaría de Relaciones Exteriores, dated 2007-09-18.
} 
a more profound engagement with North America, insofar as it expanded the trilateral agenda beyond NAFTA's exclusive focus on market access.

\subsection{Problem \#3 The Thickening of America's Borders}

The 9/11 terrorist attacks prompted the imposition of new security controls along the United States' borders with Mexico and Canada. In the months following $9 / 11$, the United States was seized by a homeland security mentality. Within hours of the terrorist attacks, the Canada-U.S. border was virtually shut down. The average wait time for trucks crossing the border rose from one to two minutes to ten to fifteen hours. The Canadian Vehicle Manufacturers' Association estimated the cost to manufacturing facilities was between $\mathrm{C} \$ 1$ million and $\mathrm{C} \$ 1.5$ million per hour. ${ }^{71}$ Integrated industries across North America were suddenly faced with the potential of massive disruptions to just-in-time deliveries. This situation presented several threats to Canadian interests, such as the possibility that, in the event of further disruptions, American firms might decide to stop investing in North American supply chains.

This development raised the spectre of transcontinental firms encountering new security-related transaction costs on cross-border trade. One observer commented that instead of progressing to even freer movement of goods and people, the trade pact had become "NAFTA-minus" after 9/11, with new border burdens, new surveillance technology, and new advanced clearance requirements for businesses. ${ }^{72}$ This was especially disconcerting given that the top ten land ports in North America accounted for

\footnotetext{
${ }^{71}$ Peter Andreas, "The Tale of Two Borders: The U.S.-Canada and U.S.-Mexico Lines after 9-11," in The Rebordering of North America, eds. Peter Andreas and Thomas J. Biersteker, 10.

${ }^{72}$ Clarkson, "The View from the Attic: Toward a Gated Continental Community?", 83.
} 
more than eighty percent of the value of all goods that entered and exited the continent. ${ }^{73}$ If a balance between trade facilitation and security could not be reached, North American competitiveness would surely decline further as a result of new costs imposed by tightening borders.

The fear that the growing influence of the American homeland security bureaucracy would create added costs for cross-border trade was palpable. One official with the Canadian Council of Chief Executives characterized the challenge as the need to convince North American leaders that competitiveness and security should be treated as equal, indivisible priorities. ${ }^{74}$ This concern was certainly not limited to the private sector. One of Canada's senior North American officials, Jon Allen, told a Parliamentary Committee in March 2003 that "Homeland security is probably the greatest challenge that we face. Security is driving the political agenda in the U.S, as you know, in a way that has no real parallel in Canada." ${ }^{, 75}$ At the Privy Council Office, senior bureaucrats were similarly possessed by the fear that another terrorist event in North American could undermine all of the economic advantages accumulated from opening the Canada-U.S. border to free trade under NAFTA and the Canada-U.S. Free Trade Agreement. ${ }^{76}$ Not only were PCO officials concerned about preventing another border shut down, but they were also concerned that the Americans would dismiss Canada's trade facilitation interests, in pursuit of a narrowly focused security agenda.

The PCO's concerns were communicated to a Parliamentary committee in March 2003 by Robert Fonberg, the Deputy Secretary to the Cabinet responsible for

\footnotetext{
${ }^{73}$ Condon and Sinha, Drawing Lines in the Sand and Snow, 20-21.

${ }^{74}$ Confidential interview with an official at the Canadian Council of Chief Executives, dated 2007-08-23.

${ }^{75}$ Canada, Senate Standing Committee on National Security and Defence, Evidence, Issue $12,37^{\text {th }}$ Parl., $2^{\text {nd }}$ Sess., 17 March 2003, "Testimony of Jon Allen (Director General, North America Bureau, DFAIT)."

${ }^{76}$ Confidential interview with a former official at the Privy Council Office, dated 2007-08-14.
} 
coordinating the Smart Borders agenda and the development of the North American

Initiative:

Going back to September 11 and the border being shut down, obviously, for national security and public security reasons, it took not a very long time before people realized that certainly our lifeblood on the economic side was getting choked off. There were long line ups of trucks at the Windsor-Detroit corridor and other border crossings. It quickly became apparent that auto plants would be at risk because of the just-in-time delivery model that they use on either side of the border. The economic security side of this got choked off quickly. ${ }^{77}$

Consequently, the emphasis for Canadian officials under Fonberg's direction was to ensure that the enforcement mindset would not trump the facilitation mindset on either side of the border.

There were numerous economic concerns cited by PCO officials who worked hard to offset the thickening border through initiatives like Smart Borders and the North American Initiative (NAI). These officials were aware of the increased shipment costs induced by longer wait times at the border. ${ }^{78}$ A study conducted by the U.S. Federal Highway Administration estimated that the transportation industry lost 2.6 million hours per year in delay time, at a cost of at least US\$88 million. ${ }^{79}$ The impact on the DetroitWindsor area was a paramount concern for these officials. The auto industry was so integrated in that region that the production of a single car involved four to five border crossings, since everything in the corridor was done on a regional basis. ${ }^{80}$ Two days after

\footnotetext{
${ }^{77}$ Canada, Senate Standing Committee on National Security and Defence, Evidence, Issue $12,37^{\text {th }}$ Parl., $2^{\text {nd }}$ Sess., 17 March 2003, "Testimony of Robert Fonberg (Deputy Secretary to the Cabinet, Operations)."

${ }^{78}$ Pierre Martin, "The Mounting Costs of Securing the 'Undefended' Border," Policy Options (July August 2006), 16.

${ }^{79}$ Condon and Sinha, Drawing Lines in the Sand and Snow, 41.

${ }^{80}$ Confidential interview with a former official at the Privy Council Office, dated 2007-09-19.
} 
the attacks, Chrysler announced that it would have to temporarily close an assembly plant, and Ford made a similar announcement the next day. ${ }^{81}$

The threat of a thickening U.S. border was far more severe in Mexico. The U.S.Mexico border had been the subject of increased scrutiny in recent decades. Burgeoning trade between the two countries had opened up trade corridors that could also be exploited by drug traffickers and human smugglers. In response, the United States hardened its southern border, augmenting its enforcement and detection capability. ${ }^{82}$ The enforcement apparatus that existed prior to $9 / 11$ was structured to detect and apprehend illegal migrants and the shipment of drugs. It was not equipped to deter the few individuals who were intent on committing terrorist acts from crossing the Mexican border. ${ }^{83}$ A strong argument had been made to apply a risk-based approach to managing the southern border, similar to the approach the U.S. implemented with Canada. ${ }^{84}$ Yet after $9 / 11$, American security officials determined that even more resources were required along the border. They added a new security overlay on top of the already strong contingent of military, customs, drug enforcement, and immigration officers present at the border. This only increased the number of bottlenecks to trade encountered at the border. Officials at the Office of Public Policy knew that they had to respond to the larger shifts occurring in the American government with the rise of the post $9 / 11$ security

\footnotetext{
${ }^{81}$ Stephen Flynn, "The False Conundrum-Continental Integration vs. Homeland Security," in The Rebordering of North America, eds. Peter Andreas and Thomas J. Biersteker, 115.

${ }^{82}$ Andreas, "A Tale of Two Borders: The U.S.-Canada and U.S.-Mexico Lines After 9/11," in The Rebordering of North America, eds. Peter Andreas and Thomas J. Biersteker, 7. Even before 9/11, there were more U.S. Customs and Border Patrol officers stationed at Brownsville, Texas, than along the entire Canada-U.S. border [Ibid, 8].

${ }^{83}$ Andreas, "A Tale of Two Borders: The U.S.-Canada and U.S.-Mexico Lines After 9/11," in The Rebordering of North America, eds. Peter Andreas and Thomas J. Biersteker, 7.

${ }^{84}$ See Monica Serrano, "Integration and Security in North America," in International Journal 61, no. 3 (Summer 2006): 611-632; Monica Serrano, "Bordering on the Impossible: U.S.-Mexican Security Relations after 9/11," in The Rebordering of North America, eds. Peter Andreas and Thomas J. Biersteker, 62.
} 
paradigm. ${ }^{85}$ Like their Canadian counterparts, Mexican officials were equally concerned about ensuring the secure flow of goods and people across the border. For example, Foreign Minister Derbez publicly linked Mexican competitiveness to its ability to trade goods securely between the two countries. ${ }^{86}$ Similar to the Canadian approach, there was an attempt to balance security cooperation with the United States with an effort to improve trade facilitation. ${ }^{87}$ Indeed, one of Mexico's three priorities with respect to the SPP was to ensure that new security measures did not undercut the efficient flow of goods and people across the border.

The problem that emerged for both Mexico and Canada was that NAFTA did not include any provisions for security cooperation. It was for this reason that the initial response to the security challenge had to be conducted along a separate track from NAFTA. ${ }^{88}$ In Ottawa and Mexico City, the fear was that there would be no institutional arrangement to allow security and trade-facilitation officials to sit at the same table. It became clear to senior Canadian officials that, when enforcers were put together on both sides of the border, an enforcement mentality could quickly develop. ${ }^{89}$ The Smart Border Declaration and the Alianza para la Frontera were two early attempts to rectify the problem by merging the previously separate tracks of trade and security dialogue.

\footnotetext{
${ }^{85}$ Confidential interview with an official at the Secretaría de Economía, dated 2007-09-28.

${ }^{86}$ Luis Derbez, "Competitividad y Diplomacia," Instituto Mexicano para la Competitividad, http://www.imco.org.mx/ar40.php.

${ }^{87}$ Confidential interview with an official at the Secretaría de Relaciones Exteriores, dated 2007-09-18. About 1.2 million Mexicans cross the border with the United States daily. At the Laredo crossing, for example, it took about five minutes for a pedestrian to cross and half an hour for a motorist before $9 / 11$. On 12 September, it took about five hours [Andreas, "The Tale of Two Borders: The U.S.-Canada and U.S.Mexico Lines after 9-11," in The Rebordering of North America, eds. Peter Andreas and Thomas J. Biersteker, 10].

${ }^{88}$ There was a NAFTA customs subgroup that worked on border security issues in the six months after 9/11. However, it proved incapable of leading the security dialogue, since that dialogue existed on a different political track, managed by the central agencies [Clarkson, Ladly, and Thorne, "Deinstitutionalizing North America: NAFTA's committees and working groups"].

${ }^{89}$ Confidential interview with a former official at the Privy Council Office, dated 2007-09-19.
} 
However, Canadian and Mexican officials realized that these agreements would not go far enough to permanently resolve this problem. A broader framework had to be created.

Program feedback indicated the need for a new framework that could augment the existing border accords. An official who worked in the Canada-U.S. Secretariat of PCO reflected that the NAI was developed, in part, to build on the Smart Borders process. ${ }^{90}$ In Canada, there was a continuing need to demonstrate that the large resource allocations that the Canadian government had committed to security programs after 9/11 were actually having an impact on the flow of goods and services across the border. ${ }^{91}$ In this context, Smart Borders was only understood to be the initial stage of engagement with the Americans on the border file. ${ }^{92}$

At the program level, there were several indicators to suggest that Smart Borders was insufficient. Initially, it seemed as though Smart Borders did not cover enough policy sectors. Accordingly, in September 2002, bioterrorism and science and technology cooperation were added to the Thirty Point Smart Borders Action Plan; a separate side agreement, the Safe Third Country Agreement, was also negotiated with the United States. ${ }^{93}$ There was a fear among PCO officials that Smart Borders was losing momentum. As the $9 / 11$ crisis faded, other priorities came to dominate the government agenda. Momentum was also lost because some of the Smart Borders initiatives required

\footnotetext{
${ }^{90}$ Confidential interview with a former official at the Privy Council Office, dated 2007-11-06.

${ }^{91}$ Confidential interview with a former official at the Privy Council Office, dated 2007-11-06.

${ }^{92}$ Confidential interview with a former Parliamentarian, dated 2007-09-04.

${ }^{93}$ On September 9,2002, President Bush and Prime Minister Chrétien asked Secretary Ridge and Deputy Prime Minister Manley to expand the Smart Border Action Plan to cover new areas of cooperation such as science and technology and biosecurity [Canada, Department of Foreign Affairs and International Trade, "Smart Borders Action Plan Status Report," (14 December 2004), http://geo.international.gc.ca/canam/main/border/status-en.asp]. The Safe Third Country Agreement was also negotiated in the Fall of 2002, with the intention of ending claim shopping by refugees arriving in North America [Canada, Department of Finance, "Speech by Honourable John Manley Deputy Prime Minister and Minister of Finance to the Canadian-American Business Council," (Washington, D.C.: 27 September 2002), http://www.fin.gc.ca/news02/02-076e.html].
} 
investments with long time horizons: it took time for the government to complete planned infrastructure investments and to get the new information-technology systems developed and online. ${ }^{94}$ The SPP framework was able to expand the scope of Smart Borders by pairing a much broader prosperity agenda with the initial Smart Borders Action Plan; "Smart and Secure Borders" continues to be a major thematic overlay for the SPP. Mexican officials encountered negative feedback from the Alianza para la Frontera indicating that it could not be the terminal agreement for border cooperation with the United States. This was manifest in the 2004 decision to add two companion agreements to the Alianza: the Memorandum of Understanding on the repatriation of Mexican nationals and a Border Plan of Action. ${ }^{95}$ Mexican diplomats also realized that the Americans were difficult interlocutors on the security front. One official at Secretaría de Relaciones Exteriores commented that the degree to which the U.S. and Mexico were able to cooperate on security issues depended on the specific issue and varied on a caseby-case basis. ${ }^{96}$ Under the Alianza para la Frontera, the Mexican Government had escalated its bilateral security cooperation, to a degree that would have been unthinkable in Mexican policy circles in the late 1990s. ${ }^{97}$ Yet it seemed as though this enhanced level of security cooperation was not being properly perceived in Washington, which created an additional source of frustration for Mexican officials. ${ }^{98}$ Even Canadian officials at the periphery of the U.S.-Mexico security dialogue picked up on this problem. An official

\footnotetext{
${ }^{94}$ Confidential interview with a former official at the Privy Council Office, dated 2007-09-05.

${ }^{95}$ United States, Congress, $108^{\text {th }}$ Congress, $2^{\text {nd }}$ Session, Senate, Committee on Foreign Relations, United States and Mexico: Immigration Policy and the Bilateral Relationship, "Statement of Hon. C. Stewart Verdery, Assistant Secretary for Policy and Planning, Border and Transportation Security Directorate, Department of Homeland Security," 60.

${ }^{96}$ Confidential interview with an official at Secretaría de Economia, dated 2007-09-26.

${ }^{97}$ IRPP, "Remarks by the Under Secretary for North America, Gerónimo Gutierrez, at the Conference: North American Integration: Migration, Trade and Security," (Ottawa: IRPP, 2 April 2004).

${ }^{98}$ Confidential interview with an official at Secretaría de Economía, dated 2007-09-18.
} 
who worked at the PCO confided that part of the initial interest in Washington for the NAI white paper was that it presented an opportunity to use a broad prosperity agenda as a carrot to create a large enough buy-in for Mexico to attract it towards closer security cooperation with the United States. ${ }^{99}$ Mexican and American officials realized that the framework for their security cooperation had to expand beyond the limits of the Alianza.

\subsection{Problem \#4 Accepting Mexico's Place at the North American Table}

One of the most discreet but pervasive problems in the North American relationship was the need for Canada to fully accept Mexico's place at the North American table in issues beyond NAFTA and its side agreements. Traditionally, North America had existed on the basis of two strong bilateral relationships centred on the United States. The U.S. Deputy Assistant Secretary of State for North America, Linda Jewell, commented in 2003 that there was a missing link in the North American relationship between Canada and Mexico. ${ }^{100}$ As American officials gradually accepted the need to adopt a more trilateral approach, the Canadians were forced to confront their traditional obstinacy towards including Mexico at the North American table.

The Canadian refusal to accept Mexico's place at the North American table had percolated through the Ottawa bureaucracy for years. Even in November 2001, Jon Allen told Parliament, "We've heard from the Mexicans that they would like to talk about a North American perimeter. Frankly, that's not in the cards right now. The government wants to focus its attention on the 49th parallel and dealing with the movement of goods

\footnotetext{
${ }^{99}$ Confidential interview with a former official at the Privy Council Office, dated 2007-08-14.

${ }^{100}$ The Public Policy Forum, Rethinking North American Integration: Conference Report (29-30 October 2003), http://www.ppforum.ca/common/assets/publications/en/na_outcomes_final.pdf. Officials at the U.S. Embassy in Ottawa expressed a similar attitude during an interview dated 2007-09-13.
} 
and people away from the 49th parallel, to the extent it can."101 The Canadian and Mexican foreign ministers met at the Mexican Embassy in Washington soon after 9/11 to explore the possibility of a joint approach to border security. However, Canada's Foreign Minister, John Manley, told his Mexican counterpart that the nature of each country's security relationship with the U.S. was different and that Canada's security and intelligence cooperation under NATO and other military and law enforcement agencies required that Canada pursue a bilateral Smart Borders agreement with the United States, rather than a trilateral agreement on border management. ${ }^{102}$ As a Canadian diplomat explained, "While neither the United States or Mexico viewed Canadian participation in their issues as a negative, Canadians tended to view Mexican involvement in its bilateral issues with the United States as neutral at best, worse as an unwelcome complication, and at worst, as a negative." ${ }^{103}$ The principal fear that galvanized some quarters in Ottawa was that including Mexico at the table would trilateralize the border relationship with the United States; successful management of the Canada-U.S. border was one of the most treasured accomplishments of the PCO Borders Task Force and they were reluctant to jeopardize it by including Mexico. Consequently, Mexico and Canada signed two separate border accords with the United States.

Despite Canadian reticence, several indicators surfaced in the post 9/11 years demonstrating that Canada would have little choice but to accept Mexico as a complete partner at the North American table. Demographic changes were raising the profile and

\footnotetext{
${ }^{101}$ Canada, House Standing Committee on Foreign Affairs and International Trade, Evidence, $37^{\text {th }}$ Parl., $1 \mathrm{st}$ Sess., 20 November 2001, "Testimony of Jon Allen."

${ }^{102}$ Andrés Rozental, "The Security and Prosperity Partnership: An Overview," in International Journal 61, no. 3 (Summer 2006),543-544.

${ }^{103}$ Confidential interview with an official at the Department of Foreign Affairs and International Trade, dated 2007-10-02.
} 
importance of Mexican issues in the United States. As the Department of Foreign

Affairs' Director General for North America, William Crosbie, observed:

The U.S. population is slowly shifting towards the south and southwest, where Canada is less "top of the mind" and less influential. At the same time, the Hispanic population, which historically has had little contact with Canada, is a growing force in U.S. politics...Our relationship with the United States is increasingly being viewed within a trilateral context by American political leaders in the Administration and Congress. In all senses-politically, economically, socially-Mexico and the U.S. Hispanic population, dominated by MexicanAmericans, have changed the way Americans view their own society. These trends have also affected how the U.S. views its relationship with its two neighbouring governments. U.S. border policy is the most notable example. ${ }^{104}$

President Bush, himself a former border governor from Texas, was part of this change in political momentum. The weight of Canada as a player in the U.S. system was declining.

It became quite clear that Canada could no longer advance its border agenda with the United States, or advance other issues which had a direct bearing on the views of the Hispanic community in the U.S., without also factoring Mexican and Hispanic views into Canadian strategy. ${ }^{105}$ Canadian diplomats at DFAIT became powerful advocates of an alternative approach: rather than becoming the victims of this trend, they argued, why not turn growing Mexican influence in the United States to Canada's advantage $?^{106}$

Accordingly, DFAIT embarked on programs designed to provide greater awareness of Mexican influence in the United States. ${ }^{107}$

The PCO officials who first broached the NAI white paper with their counterparts at the National Security Council quickly realized that it would be impossible to pursue the NAI bilaterally. In addition to the need to use the NAI as a means to obtain greater buy-

\footnotetext{
${ }^{104}$ Canada, House Standing Committee on Foreign Affairs and International Trade, Evidence, $39^{\text {th }}$ Parl., $1^{\text {st }}$ Sess., 24 April 2007, "Testimony of William Crosbie (Director General, North America, DFAIT)."

${ }^{105}$ Confidential interview with an official at the Department of Foreign Affairs and International Trade, dated 2007-10-02.

${ }^{106} \mathrm{Ibid}$.

${ }^{107}$ Ibid.
} 
in from Mexico to the U.S. security agenda, there were also several strategic considerations that the United States could not ignore. According to one official who worked in the PCO's Canada-U.S. Secretariat, it was clear that the Americans wanted to include Mexico in part to appeal to the constituency of southern voters in the United States. ${ }^{108}$ There was also pressure mounting on Homeland Security Secretary Tom Ridge since it seemed as though he was pursuing a double standard by agreeing to Smart Border initiatives with Canada that the Americans simply could not expand to Mexico. ${ }^{109}$ Congressmen and Senators from south western states put pressure on the Bush Administration to stop treating Mexicans differently than Canadians. ${ }^{110}$ The path toward accepting Mexico as a full partner at the North American table was made easier by the fact that American officials were quick to insist that Washington would continue to treat the northern border differently than the southern border. ${ }^{111}$

The decision to include Mexico in the discussions on the NAI white paper generated a necessary internal debate in Ottawa about the Canada-Mexico relationship that had to occur before Mexico took its place at the SPP table. The internal debate was characterized on one side by those who argued that Mexico's inclusion could be a positive if Canada could use Mexico as leverage in pursuit of Canadian bilateral interests with the U.S., or on certain issues of common concern vis-à-vis the United States. ${ }^{112}$ Yet there were also concerns about instances where Mexican interests could interfere with the management of Canada's bilateral relationship with Washington. ${ }^{113}$ The fear of Canadian

\footnotetext{
${ }^{108}$ Confidential interview with a former official at the Privy Council Office, dated 2007-09-19.

${ }^{109}$ United States, Senate Committee on Foreign Relations, United States and Mexico: Immigration Policy and the Bilateral Relationship, $108^{\text {th }}$ Cong., $2^{\text {nd }}$ Sess., 23 March 2004, 89.

110 See Chapter 4, page 108.

${ }^{111}$ Confidential interview with an official at the U.S. Embassy (Ottawa), dated 2007-09-13.

112 Confidential interview with a former official at the Privy Council Office, dated 2007-09-05.

113 Ibid.
} 
officials was that by trilateralizing security cooperation, a 'Mexicanization' of the Canadian border would ensue. Canadians felt the need to stress that a different set of issues existed along the two borders, and that there were large differences in the enforcement capacity and technology available to Canadian and Mexican security agencies. $^{114}$

The scope for developing a deeper agenda under the SPP was constrained by including Mexico since it placed limits on what Canada and the United States could agree on. ${ }^{115}$ Specifically, there were certain risk-management approaches to border management that the United States simply would not agree to with Canada, because it could not extend those same programs to the Mexican border. Including Mexico ran the risk of lowering the common denominator on the sort of initiatives on which all three countries could agree and implement. ${ }^{116}$ The internal Canadian compromise was the decision to propose a model that included Mexico, but with the fundamental principle of moving at two speeds: "three can talk, but two can do."117 This reflected the PCO consensus that Canadian officials had to present a package that could include Mexico without altering Canada's traditional methods of managing its bilateral relationship with the United States.

Consistent with the approach advocated by Canadian diplomats, officials at the PCO recognized that it would be to their advantage to seize the SPP as a propitious moment to define Mexico's terms of entry to full participation at the North American table. One Canadian architect of the SPP commented that, while the offensive strategy in

\footnotetext{
${ }^{114}$ Hristoulas, "Trading Places: Canada, Mexico, and North American Security," in The Rebordering of North America, eds. Peter Andreas and Thomas J. Biersteker, 37.

${ }_{115}$ Confidential interview with a former official at the Privy Council Office, dated 2007-09-06. ${ }^{116}$ Ibid.

${ }^{117}$ Confidential interview with a former official at the Privy Council Office, dated 2007-10-03.
} 
proposing the NAI was to perpetuate and extend the Smart Borders model, the defensive strategy was to shape and control the process that would bring Mexico into the border management regime. ${ }^{118}$ If trilateral engagement was inevitable, it would be shaped on Canadian terms. Through entrenching the two-speed model, Canada was able to resolve the long standing problem of defining Mexico's role in North America beyond market access. That paved the way for the emergence of the new architecture found in the SPP.

\subsection{Budget Constraints}

As noted at the outset of this chapter, each country's budget could serve as either a promoter or constraint for the problems that existed on the government agenda. In Mexico, the budget served as a constraint: there was no new money for SPP programs and funding for the deliverables contained in the SPP work plan had to come from existing Congressional allocations to federal departments. ${ }^{119}$ In the United States, the SPP was designed to function within existing administrative and legislative authority. It was limited to pursuing national security objectives, rules, standards, and law enforcement activities already sanctioned under existing congressional authorizations. ${ }^{120}$ For the United States, the problems of greatest concern were the challenges to North American competitiveness and the need to increase security controls on its borders with Canada and

Mexico. Both of these thematic objectives were well funded under domestic programs. ${ }^{121}$

${ }^{118}$ Confidential interview with a former official at the Privy Council Office, dated 2007-09-06.

${ }^{119}$ Confidential interview with an official at Secretaría de Relaciones Exteriores, dated 2007-09-18.

${ }^{120}$ Anderson and Sands, Negotiating North America, 18.

${ }^{121}$ On the competitiveness file, the Bush Administration launched the American Competitiveness Initiative which committed US $\$ 136$ billion over ten years to increase investment in R\&D, strengthen education, and encourage innovation [United States, Department of Commerce, "Written statement on Oversight of the U.S. Department of Commerce by Commerce Secretary Carlos M. Gutierrez, Senate Committee on Commerce, Science, and Technology," http://www.commerce.gov/s/groups/public/@doc/@os/@opa/ documents/content/prod01_003231.pdf]. For the border security file, it is estimated that expenditures for domestic security programs tripled from their pre-9/11 levels reaching an estimated US\$50 billion to US $\$ 60$ 
Since the investments on border security would be occurring with or without the new architecture created by the SPP, there was little need for the Executive Branch to seek new appropriations from Congress.

Since the SPP consisted of largely ongoing departmental and agency initiatives, there was no need to seek specific new allocations from Congress. Instead, as one official at the U.S. Department of Transportation explained, the SPP became an effective management tool in Washington for executive branch departments: with no new money from Congress, officials had to work harder at what they were already doing. They had to figure out what they could do with money that was already allocated to them, and try to improve these programs by fixing inefficiencies. ${ }^{122}$ The U.S. budget constraint also precluded a new content-driven agenda from emerging, instead maintaining the concentration on key priority initiatives already well funded by Congress, or initiatives that required more efficient management.

Across the border, the Canadian government took a different approach. The SPP had a positive budget effect insofar as the Canadians used it as a catalyst for new program funding from Parliament. First, the Treasury Board Secretariat, responsible for managing the allocation of funds within departments, identified "A Strong and Mutually Beneficial North American Partnership" as one of its four whole-of-government spending priorities in the area of international affairs and national security program spending. ${ }^{123}$ By setting the strong North American partnership as a priority, it ensured that a line department could easily attach one of its ongoing bilateral or trilateral programs to this strategic

billion in 2007, with billions more in state and local money [Karen DeYoung, "A Fight Against Terrorism-and Disorganization," Washington Post, August 9, 2006, sec A].

${ }^{122}$ Confidential interview with an official from the Department of Transportation, dated 2007-12-14.

${ }^{123}$ Canada, Treasury Board Secretariat, "RPP Overview for Parliamentarians 2007-2008: International Affairs," http://www.tbs-sct.gc.ca/wgpp-prpg/pa-ds-eng.aspx?Rt=991\&Pa=1092. 
outcome. This matched the SPP's design of building on existing initiatives rather than advancing new substantive programs.

The Canadian government also used the SPP as the justification for a new envelope of border infrastructure and security related spending in Budget 2006. Specifically, Budget 2006 allocated $C \$ 303$ million in new program spending to implement a risk-management border strategy. It also allocated $\mathrm{C} \$ 460$ million for pandemic preparedness consistent with the SPP deliverable of developing a North American Avian Influenza Pandemic Preparedness Plan, and C $\$ 5.5$ billion over four years for a new Highways and Border Infrastructure Fund, ${ }^{124}$ which would advance the SPP commitment to build a new border crossing at Detroit-Windsor. These budget outlays represented the Canadian priorities of addressing the competitiveness challenge created by the ever present threat of a thickening border.

The four main problems identified on the government agenda explain why government actors were receptive to the process-driven SPP, since it created the architecture necessary to respond to the problems on the agenda: the fears about North American competitiveness motivated a strong prosperity overlay; the unfinished NAFTA agenda underscored the need for a framework capable of re-energizing ongoing initiatives through the assignment of new timetables, deliverables, and reporting requirements; the thickening of the border required that Canada and Mexico move to a more expansive and trilateral approach to border management that was paired with a prosperity agenda; the acceptance of Mexico's place at the North American table generated the development of a

${ }^{124}$ Canada, Department of Finance, Canada's New Government: Turning a New Leaf, (Ottawa: Department of Finance, 2006), 131-132. Canada's 2005 International Policy Statement also identified a "Strategy for our North American Partnership" as one of four departmental priorities. The SPP was identified as the hallmark initiative for this strategic priority [Canada, Department of Foreign Affairs and International Trade, A Role of Pride and Influence in the World: Canada's International Policy Statement, (Ottawa: Department of Foreign Affairs, 2005)]. 
two-speed model for managing North American relations. Finally, the budget constraint in the United States and Mexico favoured the adoption of a limited agenda built around existing initiatives. The next chapter will assess the policy alternatives available to policy actors seeking to create a new architecture that would be capable of addressing many of these problems. 


\section{CHAPTER 2: PRIVATE SECTOR ACTORS IN THE POLICY STREAM}

The previous chapter identified several problems that attracted the attention of policy actors in and around government. On a parallel track to this identification of problems, a separate discourse was occurring among members of a dedicated policy community of academic specialists, government officials and private sector lobbyists who focused their attention on the development of policy options for managing the North American relationship. In the context of the SPP, the following two chapters will explain how policy actors in the three countries reached consensus on a broad model for North American cooperation, while falling short of reaching consensus on the content that should populate this model. Where consensus did exist, it was centered on the creation of a framework that balanced security needs with trade facilitation needs, that included a place for Mexico at the North American table, and that accepted an incremental pace and sequencing for moving toward deeper integration. This bifurcated outcome was produced by the rise of an architecture-centric model in the policy stream and the gradual decline in the policy network of the content-driven options for North America. By applying the policy stream framework of the multiple streams model, this chapter will trace the ebb and flow of three specific policy alternatives generated in the private sector and describe the process of consensus-building within this policy network.

\subsection{The Policy Stream in the Multiple Streams Model}

The policy stream provides a structured framework for explaining the process of alternative specification. Specifically, this framework is useful for analyzing the rise and fall of various policy proposals within a specialized community of actors. The policy 
community is composed of policy-issue specialists, inside and outside of government, who are well acquainted with one another and are familiar with each other's ideas. ${ }^{125}$ With respect to the SPP, the policy community consisted of organized business groups, central agency and line department officials spread across the three countries, privately organized research units, and well respected academics who had written extensively on the subject of North American integration.

Within this policy community, various policy alternatives are evaluated and debated. The process of narrowing policy options is akin to that of natural selection in biology. Just as molecules float around in a biological primeval soup, policy ideas float around in these policy communities, in what John Kingdon calls 'the policy primeval soup.' Policy actors encounter ideas, evaluate them, argue with one another, persuade one another, and solve intellectual logjams. ${ }^{126}$ Policy options and ideas bump up against one another in various ways, leading to the recombination of previously existing ideas. ${ }^{127}$ Just like the process of natural selection, some of these molecules survive through recombination, while others fade. Through this process, an initially large pool of policy options is pared down over time to a select list of policy alternatives ready for decisionmakers. The diffusion process will be approximated through studying a series of conferences and consensus-building events, as well as analyzing the agenda-setting process for the government-inspired North American Initiative.

Often, recombination involves the re-packaging of existing ideas. This repackaging is evident in the context of the Security and Prosperity Partnership. Chapter 3 will demonstrate that the setting of the NAI agenda consisted of incorporating ongoing

\footnotetext{
${ }^{125}$ Kingdon, Agendas, Alternatives, and Public Policies, 117.

${ }^{126}$ Ibid, 124-125.

${ }^{127}$ Ibid, 116-117.
} 
bilateral initiatives into the previously developed model of managing relations from the centre of government. Re-combination on its own, however, is insufficient to explain the rise of a policy alternative in this stream. Accordingly, in the latter half of Chapter 3, a second set of variables will be used to explain how the NAI rose to become the policy alternative of choice on the three governments' agendas. These variables are: technical feasibility; values acceptability, as measured through receptivity of lawmakers and anticipated public acquiescence; and tolerable resource costs. ${ }^{128}$ Each of these variables acted as a lubricant in the policy stream; they combined to hasten the emergence of the process-driven policy alternative in the primeval soup.

The multiple streams model posits that recombination must occur in tandem with a softening up process within the policy community. The softening up process is important for moving a policy along in the policy stream; it often involves policy entrepreneurs greasing the skids. ${ }^{129}$ It is really about being proactive so that much of the heavy lifting in terms of selling an idea is done by the time that a policy window actually opens. In the case of the SPP, the process of softening up government actors coalesced around the NAI model. However, the private sector members of the policy network reached their own policy consensus, manifest in the report issued by the Council on Foreign Relations' Independent Task Force on the Future of North America. The divergence between these two consensus positions was never fully bridged by the time of the Waco Summit, indicating that the softening up process may have ended prematurely. This fissure within the policy community, however, is now being sealed through the ongoing work of the North American Competitiveness Council.

\footnotetext{
${ }^{128}$ Ibid, 131.

${ }^{129}$ Ibid, 128-130.
} 


\subsection{Policy Alternatives in the Private Sector}

Numerous actors in the private sector and academia contributed a variety of policy proposals for deepening North American economic and political relations. These policy alternatives can be broadly organized into three categories: the big vision; the construction of new supranational institutions for North America; and incremental approaches to integration.

The 'Big Vision' referred to policy options that were designed to hasten sudden and transformative change to the North American relationship. ${ }^{130}$ Though the Big Vision assumed various forms, most variants involved the adoption of a North American customs union and a common security perimeter. Cognizant of the challenges posed by heightened American security controls along its borders, advocates of the big vision sought to seize the opportunity presented by the events of $9 / 11$ to package a customs union with incentives such as an energy security pact that would create a large enough buy-in from politicians in Washington to cut across parochial political interests. The strongest advocates of this policy alternative were found in Canada, spread across the business community, think tanks, and academia. Their proposals were premised on the potential a customs union held for permanently eliminating trade disputes with the United

\footnotetext{
${ }^{130}$ Examples of the Big Vision are found in several publications. See Wendy Dobson, "Shaping the Future of North American Economic Space," C.D. Howe Institute, The Border Papers, no. 162 (April 2002); William Dymond and Michael Hart, "Common Borders, Shared Destinies: Canada, the United States, and Deepening Integration," (Ottawa: Centre for Trade Policy and Law, November 2001); Danielle Goldfarb, "The Road to a Canada-U.S. Customs Union: Step-by-Step or in a Single Bound?" C.D. Howe Institute, The Border Papers, no. 184 (June 2003); Allan Gotlieb, A North American Community of Law. Presentation to Borderlines Conference (Washington, D.C.: February 27, 2003), http://www.wilsoncenter. org/events/docs/gotlieb.doc; Gary Hufbauer and Jeff Schott, "The Prospects for Deeper North American Economic Integration: A US Perspective," C.D. Howe Institute, The Border Papers, no. 195 (January 2004); Axel Huelsemeyer, "Toward Deeper North American Integration: A Customs Union?" CanadianAmerican Public Policy Occasional Paper no. 59 (Canadian-American Centre, University of Maine, October 2004).
} 
States. ${ }^{131}$ Within the Canadian policy community, divergent views emerged about how to proceed with the creation of a customs union. On one side of the debate were actors who promoted an evolutionary approach to creating a customs union, an approach based on eliminating costly rules of origin wherever possible. ${ }^{132}$ Other proponents of the Big Vision wanted the customs union to be introduced in one fell swoop, without regard to pace and sequencing. ${ }^{133}$ Mexican actors also promoted Big Vision proposals, but their interest stemmed from the need to attract new investment to underdeveloped regions of the country, rather than to resolve lingering trade disputes. American supporters of the Big Vision were more cognizant than their Canadian counterparts of the need to address Mexico's development challenges. ${ }^{134}$ While Canadians advocated the Big Vision as a bilateral policy option, Mexican and American policy actors did not view the Big Vision through an exclusively bilateral lens.

The option of pursuing a customs union with the United States had been debated in the policy network prior to $9 / 11$. In contrast, debate over a common security perimeter was a fairly new phenomenon. One of the strongest advocates of pursuing a common security perimeter was the Coalition for Secure and Trade-Efficient Borders. In late 2001 , it began to advocate the adoption of a risk-management model to facilitate

\footnotetext{
${ }^{131}$ See Introduction chapter, pages 7-8.

${ }^{132}$ The argument is that the cost of rules of origins tends to be highest in sectors where there is a significant difference between Most Favoured Nation (MFN) tariff rates in Canada and the U.S. When MFN rates are similar, it is easier for firms to circumvent the costly rules of origin process by exporting under MFN rates, rather than the NAFTA rate [Danielle Goldfarb, "The Road to a Canada-U.S. Customs Union: Step-by-Step or in a Single Bound?" C.D. Howe Institute, The Border Papers, no. 184 (June 2003), 25].

${ }^{133}$ Wendy Dobson and Allan Gotlieb fall under this category of Big Vision proponents. The distinction between these two commentators is that Gotlieb advocated the development of a community of laws that would create new law-based economic and security regimes common to Canada and the United States, described as "customs union-like" and "security perimeter-like." In contrast, Dobson spoke more in terms of weaving together strategic trade-offs, rather than achieving the Big Vision through the construction of a new legal foundation for Canada-U.S. relations.

${ }^{134}$ See Gary Hufbauer and Jeff Schott, "The Prospects for Deeper North American Economic Integration: A US Perspective," C.D. Howe Institute The Border Papers, no. 195 (January 2004).
} 
movement of low risk goods and people and reallocate resources to high risk goods and people. ${ }^{135}$ The Coalition was a grouping of over forty private sector firms and industry associations that shared an interest in mitigating the trade effects of heightened security measures along the Canada-U.S. border. ${ }^{136}$ Its chief spokesperson was former Canadian Cabinet minister and President of the Canadian Association of Manufacturers and Exporters, Perrin Beatty.

In the years following $9 / 11$, the Coalition published a series of reports and Beatty testified several times before Parliamentary committees in an attempt to soften up legislators on the need for Canada and the United States to create a "zone of confidence."137 This proposal was expanded in subsequent Coalition reports to include appeals for the construction of land pre-clearance sites away from the border; the harmonization of standards affecting the entry of goods into North American markets; joint Canada-U.S. customs inspections teams at major ports of entry; a single clearinghouse in the Canadian government for screening incoming visitors to Canada; harmonization of visa waiver lists; strengthened entry-exit tracking system; and greater private sector investment in supply chain security and pre-clearance registration

\footnotetext{
${ }^{135}$ Canadian Manufacturers and Exporters' Association, "Statement of Principles- Coalition for Secure and Trade-Efficient Borders: Rethinking our Borders," http://www.cme-mec.ca/national/documents/ bordercoalition.pdf.

${ }^{136}$ The steering committee consisted of prominent members of the business community, including the CEO of the Canadian Chamber of Commerce, Nancy Hughes Anthony; the vice president of the Business Council on National Issues (the predecessor to the Canadian Council of Chief Executives); the Canadian Federation of Independent Businesses; and the Can-Am Border Trade Alliance. [Coalition for Secure and Trade-efficient Borders, Steering Committee, http://www.cita-acti.ca/english/View.asp? $x=339 \& \mathrm{mp}=326]$ ${ }^{137}$ The proposal was articulated in a letter to the Prime Minister and Members of Parliament on 13 November 2001 [Canadian Industrial Transportation Association, "Letter to the Prime Minister," (13 November 2001), http://www.cita-acti.ca/english/View.asp? $x=338 \& m p=326]$. In October 2001, Beatty testified before the Canadian House of Commons promoting the Zone of Confidence proposal [Canada, House Standing Committee on Foreign Affairs and International Trade, Subcommittee on International Trade, Trade Disputes, and Investment, Evidence, $37^{\text {th }}$ Parl., $1^{\text {st }}$ Sess., 18 October 2001]. In April 2003, he promoted this risk-based approach to a Senate Committee [Canada, Senate Standing Committee on Foreign Affairs, Proceedings Issue 13, $37^{\text {th }}$ Parl., $2^{\text {nd }}$ Sess., 1 April 2003].
} 
programs. ${ }^{138}$ The coalition was a consistent advocate of the zone of confidence

proposal. ${ }^{139}$ The message was clear: Canada had to strengthen its national security

regime to ensure that the country would not be used as a conduit for high risk goods and

travelers, while maintaining the efficient flow of low risk goods and travelers across the

border. ${ }^{140}$ Not surprisingly, the Coalition's proposals excluded Mexico.

An even bigger vision for the continent was proposed by American University's

Robert Pastor; albeit a vision of North America defined primarily through the prism of the U.S.-Mexico relationship. ${ }^{141}$ Pastor's proposals sought to hasten the economic development of Mexico and the forging of a political community in North America. He premised his proposals on his conviction that that North American economic and social integration was occurring and had irrevocably bound the three countries together. His proposals advocated the need to build supranational institutions and establish a North American agenda that would be capable of accelerating the pace of continental integration and closing the economic development gap between Mexico and its northern neighbors. ${ }^{142}$ Pastor's proposals merited significant attention because he was able to obtain buy-in from senior politicians and officials in the government of Vicente Fox. He

\footnotetext{
${ }^{138}$ Coalition for Secure and Trade-Efficient Borders, Rethinking our Borders: A Plan of Action (3 December 2001), http://www.cme-mec.ca/pdf/planforaction.pdf.

${ }^{139}$ The Zone of Confidence proposal was dependent on three lines of security: (1) detecting problems offshore before they arrived in North America, which required enhanced data and intelligence sharing between Canada and the U.S.; (2) stopping problems at the first point of entry into North America, which required enhanced customs and immigration procedures; (3) moving clearance of low risk goods and people away from the physical border. The proposal was as a bottom-up approach to integrating existing border initiatives with new programs to fill gaps identified by collaborative public-private sector dialogue [Canadian Manufacturers and Exporters' Association, "Statement of Principles- Coalition for Secure and Trade-Efficient Borders: Rethinking our Borders," http://www.citaacti.ca/english/ View.asp?x=339 $\& m p=326]$.

${ }^{140}$ Canadian Manufacturers and Exporters' Association, "Statement of Principles- Coalition for Secure and Trade-Efficient Borders: Rethinking our Borders," http://www.citaacti.ca/english/

View.asp? $\mathrm{x}=339$ \&mp $=326$

${ }^{141}$ See Pastor, Toward a North American Community.

${ }^{142}$ See footnote 2 on page 5 of the Introduction chapter for details on Pastor's proposals.
} 
was a friend of Fox's first Foreign Minister, Jorge Casteñeda, and he enjoyed easy access to President Fox. In fact, many of the proposals for a NAFTA Plus advanced by the Mexican government mirror Pastor's blueprint. He also succeeded in getting Texas Senator John Cornyn to introduce a bill on the Senate floor in October 2004 calling for the establishment of a North American Investment Fund; this bill, however, was never passed. ${ }^{143}$ Finally, he served as a vice-chair for the Council on Foreign Relations Task Force. From that position, he was able to advocate his proposals, many of which were included in the Task Force's final report.

In its April 2005 report, entitled, A Compact for North American Competitiveness, the Council of the Americas, a business lobby group, advocated a grand bargain under which the U.S. and Canada would work with Mexico to mobilize public and private sector investment to develop poorer regions of Mexico in exchange for a commitment from Mexico to harmonize its regulations, strengthen the rule of law, and upgrade its infrastructure in order to attract longer term domestic and foreign investment. ${ }^{144}$ The key mechanism for this grand bargain was reminiscent of Pastor's advocacy of a development fund for Mexico. Predictably, this economic development gap and the need for the creation of a North American Investment Fund also figured prominently in the final report of the Independent Task Force on the Future of North America.

The third slate of policy alternatives for the future of North America was presented as a series of incremental steps towards North American integration. The incremental approach rested on the premise that future border policies should reflect the

\footnotetext{
${ }^{143}$ North American Investment Fund Act of $2006,109^{\text {th }}$ Cong., $2^{\text {nd }}$ Sess., S.R. 3622.

${ }^{144}$ Council of the Americas, A Compact for North American Competitiveness: A Strategy for Building Competitiveness within North America (April 2005), http://www.as-coa.org/files/PDF/pub_151_92.pdf. Although the report was issued after the Waco Summit, its contents were debated and discussed prior to the March 2005 summit.
} 
co-dependency of security and prosperity. So long as that balance was achieved between trade facilitation and security, there was no need to package initiatives in a grand bargain or rush towards a customs union or security perimeter. ${ }^{145}$

In the business community, the Canadian Council of Chief Executives (CCCE) came closest to championing the pursuit of a pragmatic and realistic incremental approach to North American integration. The CCCE's proposals were first unveiled in January 2003 with the launch of its North American Security and Prosperity Initiative (NASPI). The NASPI went beyond mere border facilitation, which had been the theme of the Coalition for Secure and Trade-Efficient Borders, to address the linkages between the broad concept of prosperity and the new security regime that had arisen in the U.S.

The central tenet of the NASPI was that security and prosperity had to be treated as complementary and co-dependent. The CCCE contended that Canada and the United States already worked together through a vast network of formal and informal ties. ${ }^{146}$ The proposal was not intended to pave the way for supranational institutions, nor for a customs union or security perimeter. Rather, the concept was to generate action on five core priorities: borders, regulatory convergence, a resource pact, strengthened defence cooperation, and a new institutional framework based on joint commissions to foster

\footnotetext{
${ }^{145}$ One of the earliest articulations of the incremental approach was a February 2003 report released by the Conference Board of Canada. The Conference Board argued that Canada should take a pragmatic and flexible approach to North American integration, given that bilateral cooperation with the United States could be enhanced through a series of one-off agreements that further trade and investment liberalization, such as Smart Borders or the Safe Third Country Agreement. The Conference Board advocated a strategy that would harness new technology to move clearance activity away from the border, and supported efforts to harmonize regulations and standards across Canada and the United States. Unlike the advocates of the Big Vision, this approach did not require the packaging or linking of issues. Instead, steps to eliminate nontariff barriers to the movement of goods and people could proceed on a separate track from discussions of other issues such as infrastructure investments, shared responsibility for new arrivals to the continent, land pre-clearance, or increased resource deployments at the border [Conference Board of Canada, In Search of a New Equilibrium in the Canada-U.S. Relationship (Ottawa: February 2005), 2; 15; 19-23; 37].

${ }^{146}$ Canadian Council of Chief Executives, New Frontiers: Building a $21^{s t}$ Century Canada-United States Partnership in North America (Ottawa: April 2004), 5.
} 
coordination and prevent and resolve conflicts. ${ }^{147}$ The CCCE was one of the few Canadian members of the policy community to consider a substantive role for Mexico in any future North American initiative. The position articulated in the NASPI was, "If all three countries can agree jointly on an individual initiative, they should move forward together. If any two can do so, the third should be free to join whenever it makes sense to do so." 148 This approach was consistent with the two-speed model popular among government actors in the policy community. This willingness to include Mexico was a reflection of the political capital that Tom d'Aquino had invested in advocating for closer political and economic ties between Canada and Mexico.

The President of the CCCE, Tom d'Aquino, became an early and powerful proponent of a framework that captured the co-dependency that exists between security and prosperity. One former PCO official believed that the Canadian CEOs tended to view Prime Minister Martin's initiatives with respect to the United States as diffuse; the CEOs did not feel that Paul Martin was properly focused on the imperative of maintaining an open border and good relationship with the United States. ${ }^{149}$ The CCCE made a concerted effort to soften up government officials in all three countries. In April 2004, it released New Frontiers, which contained fifteen specific recommendations based on the five core principles of the NASPI. The publication of New Frontiers was the tip-off point for the well-connected d'Aquino. In the intervening period, he pursued a 'thousand points of light strategy,' in an attempt to get multiple respected and eminent persons,

\footnotetext{
${ }^{147}$ Canadian Council of Chief Executives, "Security and Prosperity: Toward a New Canada-United States Partnership in North America," (January 2003), 1.

148 Ibid., 6.

${ }^{149}$ Confidential interview with a former official at the Privy Council Office, dated 2007-09-05.
} 
representing a broad spectrum of society, to debate the ideas contained in the NASPI. ${ }^{150}$

The culmination of this strategy was the creation of the Council on Foreign Relations Independent Task Force on the Future of North America, which received its Canadian funding from money set aside by Canadian CEOs for the NASPI.

Tom d'Aquino's lobbying efforts were also credited for generating interest within the U.S. business community on the issue of North American competitiveness. In fact, the American business community adopted a similarly pragmatic approach to the CCCE, as manifested in A Compact for North America, a report released just after the Waco Summit by the Council of the Americas. ${ }^{151}$ Although the report identified closing the development gap with Mexico as the foremost priority, the Compact articulated an incremental approach with particular attention to pace and sequencing. ${ }^{152}$ D'Aquino also promoted the NASPI in meetings the CCCE held with Mexican CEOs. ${ }^{153}$

\subsection{Private Sector: Softening Up}

The policy primeval soup did not suffer from a lack policy alternatives. To the contrary, an intense period of policy debate and diffusion was required to sift through these competing policy alternatives and reach a level of consensus within the policy community. While advocates of all three policy options shared a common desire to create

\footnotetext{
${ }^{150}$ Confidential interview with a senior official at the Canadian Council of Chief Executives, dated 200708-23.

${ }^{151}$ The Council of the Americas represents over 180 Fortune 500 companies that share a commitment to promoting free and integrated markets across the Western Hemisphere.

${ }^{152}$ For example, the Compact called for the three economies to move towards, "the equivalent of a borderless economy" in the long-run, though in the short run it only called for more modern standards for processing imports at the border [Council of the Americas, A Compact for North American Competitiveness, http://www.as-coa.org/files/PDF/pub_151_92.pdf].

${ }^{153}$ Canadian Council of Chief Executives, "Canada and Mexico Building a Shared Future for in North America, Notes for an Address to the Mexico Business Summit by Thomas d'Aquino," (Veracruz: 20 September 2004), http://www.ceocouncil.ca/publications/pdf/613fd58b4495b89c97a4dfe304f 1e069/Notes_for_Remarks_by_Thomas_d_Aquino_to_the_Mexico_Business_Summit_September_20_2 004.pdf.
} 
a new agenda capable of reconciling security and trade facilitation interests, members of the policy network were divided over important questions. The largest disagreements among policy actors were over the issues of the pace and sequencing for North American integration and Mexican inclusion. The consensus moment for private sector members of the policy community arrived with the report released by the Independent Task Force on the Future of North America.

The series of conferences that took place between 2001 and 2005 on the subject of North American integration provided an opportunity for academics, government officials, and business groups to debate the full range of policy alternatives that existed in the policy soup. These conferences also permitted policy options to be disseminated to the wider policy community through the publication of conference proceedings and essays. ${ }^{154}$ The debate began with powerful arguments for a customs union, common security perimeter and a grand strategic bargain with the United States. ${ }^{155}$ The major concern attached to these proposals were the associated sovereignty trade-offs. ${ }^{156}$ However,

\footnotetext{
${ }^{154}$ For example, most of the Couchiching conference presentations were published by the Canadian Institute for International Affairs in International Journal. The three conferences sponsored by the IRPP produced numerous essays on the subject of North American integration. A large collection of these essays was published in The Art of the State, Vol. II: Thinking North America, eds. Thomas J. Courchene, Donald Savoie, and Daniel Schwanen (IRPP: Montreal, 2004).

${ }_{155}$ In December 2001, the Brookings Institution hosted a conference that debated two options: moving beyond NAFTA or fully implementing NAFTA [Peter Hakim and Robert E. Litan, eds, The Future of North American Integration (Washington: Brookings Institution, 2002), 12]. In February 2002, the Watson Institute at Brown University hosted a conference to discuss ideas about the shape of a common security perimeter [Brown University, "Transcript: the Re-bordering of North America: Integration or Exclusion after 9/11 ?" Watson Institute (Providence: 5 February 2002), http://www.watsoninstitute.org/news detail.cfm?id=38]. In December 2002, the Institute for Research on Public Policy (IRPP) organized a conference to examine the first ten years of NAFTA; it examined whether social and economic integration was creating a North American Community.

${ }^{156}$ The IRPP, Brookings Institution, and Brown University conferences all examined this subject. One proposal was to model the development of a security perimeter in a manner that would allow each country to retain sovereignty in many areas, only ceding sovereignty on trade, investment, and customs [Brown University, "Transcript: the Re-bordering of North America: Integration or Exclusion after 9/11?" Watson Institute (Providence: 5 February 2002), http://www.watsoninstitute.org/news_detail.cfm?id=38]. The 2003 Couchiching Summer Conference also considered the sovereignty implications of deeper integration [David
} 
momentum gradually shifted in the direction of an incremental approach toward integration that would obviate most of these sovereignty concerns. ${ }^{157}$ As the sovereignty concerns began to fade, proponents of adopting a more incremental pace and sequence for North American integration became more prominent. At the 2003 Couchiching Summer Conference, which was attended by senior Canadian and Mexican government officials, this preference for an incremental approach was expressed in one conference finding that stated there was no perceived appetite in any of the three nations to embark on a "grand bargain" to bring North America into political or economic alignment. ${ }^{158}$ A similar conference finding was produced at a symposium organized by the Public Policy Forum in October 2003, which included participation from high level government officials from the three countries and the business community. ${ }^{159}$ The other major trend in the conference circuit was an increased acceptance that Mexico would have to be included in

McGowan, "The prospects of a North American project: The 72nd Annual Conference of the Couchiching Institute on Public Affairs," International Journal 58 no. 3 (Summer 2003): 415-418].

${ }^{157}$ By 2003, conferences on the subject of North American integration began to hear evidence that sovereignty fears were exaggerated. For example, the Government of Canada's Policy Research Initiative presented the findings of its study at the Couchiching Summer Conference. This study indicated the fears of a trade-off between integration and sovereignty were exaggerated. The report concluded that Canada would not be at risk of losing its treasured social programs by pursuing deeper integration [Couchiching Online, 72 ${ }^{\text {nd }}$ Annual Summer Conference, 7-10 August 2003, "Renee St. Jacques: Sovereignty or Standard of Living: is there a trade off?," http://www.couch.ca/history/index.html]. In October 2003, a similar finding was presented to a conference on North American Integration organized by the Public Policy Forum. The purpose of the conference was to assess the results of a public opinion poll conducted by Ekos Research on North American attitudes. The poll results indicated that dissent on major political issues, such as the 2003 Iraq War, could exist without disrupting the process of economic integration [The Public Policy Forum, Rethinking North American Integration, Conference Report, (29-30 October 2003), http://www.ppforum.ca/common/assets/publications/en/na_outcomes_final.pdf].

${ }^{158}$ David McGowan, "The prospects of a North American project," 415-418.

${ }^{159}$ The Public Policy Forum Conference attracted several high level participants including: Canada's Industry Minister; the key architect of the North American Initiative, Jonathan Fried; Assistant Deputy Ministers from Industry Canada and Foreign Affairs; the Director General for Public Opinion at Presidencia; U.S. Deputy Assistant Secretary of State for North America, Linda Jewell; representatives from the Canadian Council of Chief Executives and the Canadian Chamber of Commerce; and a host of mid-level officials from federal departments and provincial governments [The Public Policy Forum, Rethinking North American Integration, Conference Report, (29-30 October 2003), http://www.ppforum.ca/ common/assets/publications/en/na_outcomes_final.pdf]. 
the discussion of any future North American initiative. ${ }^{160}$ The conference circuit was also useful for eliminating discussion of certain options from the policy soup, such as the creation of a package of new supranational institutions and the adoption of a common currency.

Consensus among private sector members of the policy community emerged from the work of the Independent Task Force on the Future of North America that was established under the auspices of the Council on Foreign Relations. The Taskforce was co-chaired by John Manley, William Weld, and Pedro Aspe. Between October 2004 and February 2005, it held meetings in Toronto, New York, and Monterrey, with secretariat support provided by influential groups within the policy community: the Canadian Council of Chief Executives, the Council on Foreign Relations, and the Mexican Council on Foreign Relations. ${ }^{161}$ It brought together a cross-section of academics, former politicians and business leaders. It was certainly the highest profile meeting between business leaders and academics on the subject of North American competitiveness. ${ }^{162}$ As one participant noted, it was no small achievement to forge a consensus among independent and strong-willed academics at opposite ends of the debate on the future of

\footnotetext{
${ }^{160}$ At Couchiching, senior representatives of the Mexican government were invited to speak [Maria De Lourdes Dieck-Assad, "Is there a NAFTA plus?" International Journal 58, no. 3 (Summer 2003): 433442]. This high level participation was an important event for softening up the community of Canadian politicians and policy specialists who were sceptical about including Mexico in any future North American arrangement. Discussion of Mexico's role in a future North American initiative was also featured on the conference agenda of The Public Policy Forum since senior officials from Fox's office were invited to attend that conference. An April 2004 IRPP conference also attracted high level participation from government actors including Mexico's Under Secretary for North America, Gerónimo Gutierrez and Mexico's Ambassador to Canada [IRPP, "North American Integration: Trade, Migration, and Security," (Ottawa: April 1-2, 2004), http://www.irpp.org/events/index.htm].

${ }^{161}$ Each of these groups appointed a representative to serve as a Task Force vice chair: the CCCE chose Tom d'Aquino, the Council on Foreign Relations chose Robert Pastor, and the Mexican Council on Foreign Relations selected Andrés Rozental, a highly respected former Mexican diplomat who was close to the Fox Administration and quite active in the conferences and policy debates on North American integration. ${ }^{162}$ Confidential interview with a former official from the Government of Canada, dated 2007-10-10.
} 
North America. ${ }^{163}$ The final report of the Task Force was issued just after the meeting of the national leaders at Waco with the intention of influencing the outcome of the June 2005 SPP ministerial meeting that would populate the SPP work plan.

The consensus reached by the Task Force represented somewhat of a compromise position between the proponents of a grand bargain and those who favoured a more incremental approach. The Task Force succeeded in producing a clear consensus that Mexico should be included at the table in any future North American initiative, and that Mexican participation should proceed on the basis of a two-speed model for some areas of cooperation, though urging the countries to aim to proceed on a trilateral basis wherever possible. ${ }^{164}$ In addition, the final recommendations contained a watered down proposal for a customs union and security perimeter that established short and long term targets for reaching those objectives. ${ }^{165}$ This was an implicit acceptance within the policy community of the need to consider pace and sequencing for North American policy options, as opposed to packaging issues into a single sweeping initiative. Third, the report contained specific recommendations to narrow the economic divide between Mexico and its North American partners. Fourth, the Task Force endorsed the position shared by virtually all members of the policy community that regulatory harmonization was a necessary step toward deepening North American integration. The Task Force also endorsed proposals that were unlikely to materialize any time soon, such as proposals to

\footnotetext{
${ }^{163}$ Confidential interview with a professor at American University, dated 2007-12-14.

${ }^{164}$ Independent Taskforce on the Future of North America, Building a North American Community (New York: Council on Foreign Relations, May 2005), 5.

${ }^{165}$ The long-run objective was to establish a North American security and economic community by 2010 . In the interim, the report called for specific steps to be taken toward a common security perimeter, such as the creation of a North American border plan and joint inspection of incoming cargo at ports. In advance of the establishment of common external tariffs by 2010 , the report recommended incremental steps, such as sectoral customs unions, pursuing regulatory convergence, and improving labour mobility [Independent Taskforce on the Future of North America, Building a North American Community, vii; 8-9; 19].
} 
strengthen the North American military relationship, to sign a North American resource pact, and to negotiate an energy security agreement. ${ }^{166}$

The failure of the Independent Task Force on the Future of North America to streamline the content proposals precluded the emergence of a single, well-designed, content-driven initiative to compete with the process-driven framework that had gained traction among government actors in the policy network at the same time as the Task Force was meeting. Consensus did emerge, however, on certain architectural issues. The work of the Task Force crystallized the need to create a framework that combines security initiatives with economic initiatives. Any future North American initiative would have to reflect the co-dependency of security and prosperity. The Task Force also clearly drew a consensus in favour of including Mexico in the new North American framework through the two-speed model. Most importantly, the Task Force implicitly accepted that the pace and sequence mattered and that North American integration would have to proceed incrementally, through a series of short-term deliverables framed against achieving longer term outcomes. This consensus on architectural issues was consistent with the North American Initiative that was debated by public sector members of the policy community.

\footnotetext{
${ }^{166}$ The Task Force endorsed some of Pastor's more contentious proposals, such as the creation of a North American Investment Fund and a proposal to enhance the program lending authority of the North American Development Bank [Independent Taskforce on the Future of North America, Building a North American Community, 12-13]. In addition, private sector led discussion of strengthening North American military cooperation continues to this day, though the annual meetings of the North American Forum.
} 


\section{CHAPTER 3}

\section{ALTERNATIVE SPECIFICATION IN THE PUBLIC SECTOR}

The previous chapter traced the evolution of various policy alternatives in the policy stream. The consensus that emerged from private sector members was short on contents, but did produce agreement on the architecture for a new North American initiative: architecture defined by a two-speed model, a framework that balanced security and prosperity, and which would move at an incremental pace. These consensus principles dovetailed with the public sector's own model for North American cooperation. This model, called the North American Initiative (NAI), became the policy alternative of choice for public sector members of the policy community. This chapter will bring the policy stream analysis to conclusion by demonstrating how consensus was built around the NAI within the government sector and how the government chose to select the contents of this policy option. Finally, this chapter will employ the variables of the multiple streams model to explain why the big vision proposals were left to float in the policy soup. These same variables will then be applied to explain how the NAI came to be structured through a process of recombination that re-packaged ongoing policy initiatives under a new framework premised on the two co-dependent pillars of security and prosperity.

\subsection{Policy Alternatives in the Public Sector}

While the primeval policy soup was full of policy alternatives generated by private sector members of the policy community, a separate government sponsored model was churning its way toward the top of the pot. This policy alternative, which went by various names at different stages of the policy development process, was generally 
referred to as the North American Initiative (see Table 2). In March 2005, a modified version of the NAI was publicly unveiled as the Security and Prosperity Partnership of North America.

Table 2: The North American Initiative

The North American Initiative (NAI) was initially conceived as Canada's blueprint for defining the next level of engagement with the United States after Smart Borders. The original NAI was not envisioned as a trilateral framework; it was conceived by Canada as a bilateral initiative. The NAI White Paper consisted of an amalgam of security and competitiveness proposals; it was the first attempt to couple the emerging norms of Canada's Smart Regulations agenda with the Smart Borders agenda. From its inception, this proposal developed what would later become the two pillars of the SPP: the security agenda and the prosperity agenda. It contained a third pillar, Quality of Life, which placed an emphasis on trilateral cooperation across the health and environment sectors. This pillar disappeared because the United States preferred that the trilateral framework have a narrower focus on border facilitation and smart regulation, rather than on environmental and health issues. The NAI provided a framework and narrative that emphasized the co-dependency of security and prosperity.

Although the content of the specific NAI changed significantly between 2002 and 2005 , the underlying model for the NAI remained unchanged. American officials expressed a preference for an agenda that could generate forward momentum, instead of an agenda that would inevitably stall in the American political system over trade disputes. The Canadians did initially show interest in renegotiating the dispute resolution mechanism contained in Chapters XIX and XX of NAFTA. However, it was quickly recognized that it would not be possible to use the NAI as a trade dispute mechanism.

The NAI was publicly revealed for the first time in Fall 2004. At the end of President Bush's visit to Ottawa, a communiqué announced a New Partnership in North America (NPNA). It was under the rubric of the NPNA that trilateral negotiations began to populate the SPP agenda. The central agencies established trilateral working groups for each policy sector to submit an agenda for their sector to the SPP coordinators' meeting for approval. In the weeks leading up to Waco, officials did encounter difficulty settling on a name for the NAI. Canadian officials objected to publicly labelling it as "the North American Initiative." Finally, it was decided that the initiative would be called the Security and Prosperity Partnership of North America.

[Confidential interviews with a former official at the Privy Council Office, dated 2007-08-14; with a United States Government official, dated 2007-12-14; and with a former official at the Privy Council Office, dated 2007-10-02].

The North American Initiative was the creation of a small group of mandarins who worked in the Borders Task Force at the Privy Council Office; these were the same 
officials who had a positive experience negotiating and implementing Smart Borders. Initially, these PCO officials attempted to have Canadian Prime Minister Jean Chrétien raise the subject of the NAI during his September 2002 bilateral meeting with President Bush. However, there were no officials present in the room during the meeting, and it appears as though the NAI was never raised. ${ }^{167}$ Frustrated by the lack of political take-up for the proposal in Ottawa, a very small group of PCO officials traveled to Washington in December 2002 to present the NAI white paper to senior White House officials at an informal dinner. ${ }^{168}$ The dinner was attended by the Associate Deputy Minister of Finance Jonathan Fried, the Deputy Secretary to the Cabinet, Robert Fonberg, and Canada's Minister (Political and Public Affairs) in Washington, Peter Boehm. ${ }^{169}$ These PCO officials had established several high level White House contacts through their involvement with the Smart Borders process. In particular, Fried was well acquainted with the Deputy National Security Advisor for International Economics, Gary Edson. Following this dinner, the NAI came under the sponsorship of Edson's office.

Through these informal discussions, it became clear that the NAI had traction since officials in both Canada and the U.S. recognized they had coinciding interests when it came to smarter regulation and homeland security. Both countries also recognized that there were difficulties getting Mexico to buy-in to the security agenda. ${ }^{170}$ Hence, the decision was made to trilateralize the NAI and include Mexican officials in the discussions. Edson's Senior Director for International Economics, John Cloud, extended the invitation to two top officials at Presidencia, Eduardo Sojo and Alberto Ortega, to

\footnotetext{
${ }^{167}$ Confidential interview with a former official at the Privy Council Office, dated 2007-09-05. 168 Ibid.

${ }^{169}$ Confidential interview with a former official at the Privy Council Office, dated 2007-09-19.

${ }^{170}$ Confidential interview with a former official at the Privy Council Office, dated 2007-08-14.
} 
travel to Washington. ${ }^{171}$ The first trilateral discussions on the NAI occurred at the White House in March 2003. ${ }^{172}$ Soon thereafter, Faryer Shirzad, who had replaced Cloud, worked with the PCO's Phil Ventura and Alberto Ortega to coordinate the day-to-day work of developing the NAI model. Through this troika of central agency officials, a network was established that permitted the expansion of the management-from-the-centre model to the trilateral level.

Although the North American Initiative was a Canadian-inspired proposal, it quickly obtained buy-in from senior government officials across the three countries. Like most of the policy alternatives generated by private sector members of the policy community, the NAI balanced security interests with trade facilitation interests. There were a few prominent distinctions between the NAI and the emerging private sector consensus captured in the report of the Task Force on the Future of North America. First, the three governments had always been ahead of the private sector with respect to including Mexico in a North American initiative. The three governments had also reached a consensus much earlier than the private sector that the pace and sequencing of a new model for North American cooperation would have to be incremental. Eventually, the private sector came around to accepting these two features of a model for North American cooperation, but important differences remained over the contents of any new North American initiative. While the private sector looked for innovative approaches to the challenges facing North America, officials in the three countries who worked on the

\footnotetext{
${ }^{171}$ Confidential interview with an official at Secretaría de Economía, dated 2007-09-28. Presidencia is the central agency supporting the Mexican President. Eduardo Sojo was the chief of President Fox's Office of Public Policy (OPP) and President Fox's chief economic advisor. Alberto Ortega was head of the International and Competitiveness Unit of the OPP and Sojo's deputy.

${ }^{172}$ Stephen Clarkson, "Manoeuvring Within the Continental Constitution" in Canada Among Nations 2007 eds. Jean Daudelin and Daniel Schwanen. (Montreal: McGill-Queen's University Press, 2008), 255. This meeting was attended by Robert Fonberg, Jonathan Fried, Eduardo Sojo, Alberto Ortega and Gary Edson [Confidential interview with an official at Secretaría de Economía, dated 2007-09-28].
} 
NAI looked inward to a model they were already comfortable with: repackaging ongoing bilateral and trilateral initiatives against a security overlay, managed by the central agencies of each country. In other words, government actors in the policy community were content to create a new architecture to group existing initiatives together under a single umbrella with a compelling narrative.

In an attempt to build on the success of the Smart Border Declaration, the PCO Borders Task Force took the lead role in developing the North American Initiative. The objective for these Canadian officials was to build on the successes of the Smart Borders process by expanding its management-from-the-centre regime to cover a broader range of policy sectors. Under pressure from the Cabinet to seize the momentum generated by Smart Borders as the basis for defining the next level of engagement with the United States on the border-file, Canadian officials sketched out a model of "aggressive incrementalism" that was manifest in the 2002 NAI white paper. ${ }^{173}$ The officials who drafted the White Paper were by-in-large the same officials who had worked on the negotiation of the Smart Border Declaration. Hence, the benchmark and inspiration when drafting the NAI was what one former PCO official described as, "the magic of Smart Borders."

The "magic of Smart Borders" was nothing more than the ability of the PCO to pull together ongoing bilateral initiatives under a single umbrella and re-cast the narrative in a manner that would generate American confidence in Canada's border security regime. Specifically, Smart Borders took audit based programs that had been under development prior to December 2001 and applied them to the radically different context

${ }^{173}$ Confidential interview with a former official at the Privy Council Office, dated 2007-09-06. 
of the post $9 / 11$ security conscious environment. ${ }^{174}$ With the North American Initiative, the Borders Task Force hoped to perpetuate this experience by pairing Smart Borders with a broader economic and quality of life agenda.

For the Canadian architects of the NAI, the strategic imperative was to build on what had worked well under the Smart Borders accord: a mechanism that consisted of high level coordination between the White House and the PCO, supported by Cabinet ministers who had been tasked by their leaders to obtain a good outcome for the border file. ${ }^{175}$ It was believed that coordination from the centre would elevate and focus priorities by cutting out federal departments from the agenda-setting process. ${ }^{176}$ In fact, the very premise underlying the NAI was to take this management-from-the -centre model and expand it to include other off-border issues in the Canada-U.S. relationship, such as regulatory and environmental cooperation. ${ }^{177}$ Although, the NAI was initially designed as a bilateral initiative, Canadian officials were well aware that pressure was mounting in the United States to bring Mexico into the border management regime. ${ }^{178}$ Since this pressure was largely beyond Canada's ability to control, the NAI quickly became a defensive reaction: an attempt by Canadian officials to control and shape the process that would bring Mexico into the border management regime. ${ }^{179}$ Once it became clear that the United States wanted Mexican participation, Canadian officials saw an opportunity to define Mexico's terms of entry into a full North American partnership.

The North American Initiative, however, was not the only policy alternative being circulated by government policy actors. Mexico was well ahead of its North American

${ }^{174}$ Confidential interview with a former official at the Privy Council Office, dated 2007-09-06.

${ }^{175}$ Confidential interview with a former official at the Privy Council Office, dated 2007-09-06.

${ }^{176}$ Ibid.

${ }^{177}$ Ibid.

${ }^{178}$ See Chapter 1, pages 45-46.

${ }^{179}$ Confidential interview with a former official at the Privy Council Office, dated 2007-09-06. 
partners in proposing a much more expansive proposal for North American integration, which came to be labelled as "NAFTA Plus." 180 This proposal starts from the premise that NAFTA had failed to generate the promised economic convergence with Canada and the United States. Accordingly, the Fox Administration had a keen interest in developing new policy approaches designed to bring the economic benefits of NAFTA to all of Mexico.

The Fox Administration favoured reforms to NAFTA that could accelerate convergence between Mexico and its northern neighbours. The long term elements of the plan included a call for a customs union, common currency, and full labour mobility. ${ }^{181}$ One of the most contentious aspects of the Mexican proposal drew on Robert Pastor's idea of establishing a North American Investment Fund to direct money to poorer regions of Mexico. While many of these proposals reflected an Europeanist approach to integration, one senior Mexican diplomat explained that the European Union (EU) model was only used as a reference point by the Mexican Government. As he explained, the EU Social Cohesion Fund came with all sorts of strings and conditions attached that the Mexican Government had never discussed internally. In addition, the issues of labour

\footnotetext{
${ }^{180}$ In August and September 2000, President-elect Fox traveled to Washington and Ottawa and promoted the idea of widening and deepening NAFTA into something resembling the European Union. The proposal included freer cross-border movement of people, development assistance for Mexico, and political institutions to govern some aspects of the trilateral relationship. At the first meeting between Presidents Bush and Fox in Guanajuato in February 2001, Fox's officials decided to lead-off with the goal of reaching a bilateral migration agreement with the United States, which could then be infused into the longer-term goal of building an EU-like North American Community. The proposed migration accord included a guest worker program and regularization of status of Mexicans already working in the U.S.; a pilot program for development assistance in underdeveloped regions of Mexico-the Partnership for Prosperity; and a proposal for creating a special visa category for Mexicans and Canadians that would give them priority over other migrants in the U.S. Foreign Minister Jorge Casteñeda later remarked that at Guanajuato, "We pushed them to where they were ultimately unwilling to go." In other words, the Mexicans presented a package broader than migration and did not let the Americans cherry pick proposals from it. Casteñeda insisted that all or nothing of the package should be accepted [Pamela K. Starr, "U.S.-Mexico Relations," Center for Strategic and International Studies, Hemisphere Focus 12, no. 2 (9 January 2004), http://www.csis.org/media/csis/pubs/hf_v12_02.pdf].

${ }^{181}$ Canada, Senate Standing Committee on Foreign Affairs, Evidence Issue 2, $37^{\text {th }}$ Parl., $2^{\text {nd }}$ Sess., 5 February 2003, "Testimony of Marc Lortie (Assistant Deputy Minister, Americas)."
} 
mobility and migration were always intended to be kept on a separate track from the construction of a North American agenda. ${ }^{182}$ The Mexicans were never completely fixated on the need to create new North American institutions.

Rather than pursue politically untenable proposals, the Fox Administration proved to be much more pragmatic. The strategic imperative for officials at Presidencia was to create a cooperation chapter that could be added on top of NAFTA. ${ }^{183}$ If "NAFTA Plus" was not feasible, they were content with smaller scale initiatives that could target investment to underdeveloped regions of the country and enhance North American competitiveness without structural change. This pragmatic approach featured the pursuit of bilateral partnerships, such as the 2002 Partnership for Prosperity and the 2004 Canada-Mexico Partnership that could play off existing frameworks in a way that improved trade, investment and competitiveness in North America. ${ }^{184}$ While these initiatives fell short of the grand designs contained in the "NAFTA Plus" proposals, they contributed to keeping the subject of North American integration on the national agendas of the three countries, creating forward momentum for the consideration of policy options for North America.

\subsection{Government Sector: Softening Up}

The idea behind creating a cooperation chapter for NAFTA coincided nicely with the idea of creating a NAI agenda based on three pillars: security, prosperity, and quality of life. In fact, even a limited NAI agenda created something the Mexican government

${ }^{182}$ Confidential interview with an official at Secretaría de Relaciones Exteriores, dated 2007-09-18.

${ }^{183}$ Confidential interview with an official at Secretaría de Economía, dated 2007-09-28.

${ }^{184}$ Confidential interview with an official from the Instituto Mexicana para la Competitividad, dated 200709-26. 
desperately wanted: a working track toward deeper integration. The biggest obstacle to building this cooperation agenda was the American insistence on dual bilateralism in North America.

Officials at Presidencia saw the NAI as an excellent opportunity to stop this practice of dual bilateralism and force the U.S. Government to engage trilaterally on certain issues. ${ }^{185}$ Another Mexican diplomat commented that if the work plan created under the NAI and SPP was brought to completion, from the Mexican perspective, it would be a big step toward strengthening and deepening the North American agenda, an outcome similar to what President Fox had desired with "NAFTA Plus."186 Moreover, the NAI satisfied three specific Mexican objectives: the need to ensure balance between American security concerns and the efficient flow of goods and people across the southern border; a move beyond tariff reduction to maintain North American competitiveness; and the construction of an active agenda of North American intereststhe cooperation chapter to NAFTA. ${ }^{187}$ In addition, the security pillar allowed Mexico to better respond to the changes occurring in the homeland security bureaucracy in Washington, to link security and prosperity trade-offs and to use Canada as leverage at the North American table. ${ }^{188}$ Despite the differences in content and scope between the Canadian and Mexican policy options, the NAI was an easy sell to officials in Mexico City.

Officials at the Privy Council Office were cognizant of the politics of homeland security in the United States. Accordingly, they developed the NAI as a policy option

\footnotetext{
${ }^{185}$ Confidential interview with an official at Secretaría de Economía, dated 2007-09-28

${ }^{186}$ Confidential interview with an official at Secretaría de Relaciones Exteriores, dated 2007-09-18.

${ }^{187}$ Ibid.

${ }^{188}$ Confidential interview with an official at Secretaría de Economía, dated 2007-09-28.
} 
that emphasized improved security cooperation, in return for American buy-in to a prosperity agenda capable of enhancing the economic effects of NAFTA. The Canadians were careful to package together an agenda that was not too radical in order to obtain American buy-in. ${ }^{189}$ In the end, there was little need to soften up officials at the National Security Council, since NSC officials realized that they had to improve the level of cooperation between security and economic agencies that worked on border security issues in the U.S. ${ }^{190}$ In addition, both Canada and the United States were in easy agreement as to what the contents of the prosperity agenda should be, with a strong focus on regulatory cooperation. Officials at the NSC recognized the opportunity that the NAI would create for enticing Mexico to enter into more complete security cooperation with the United States. ${ }^{191}$ Securing Mexican buy-in to the NAI model also helped the Canadians and Americans moderate the "NAFTA Plus" proposals of the Fox Administration.

The trilateral discussions that began in March 2003 on the basis of the NAI white paper advanced the softening up process within the government sector of the policy community. This consensus building period represented the first time that the American government was willing to discuss a trilateral vision for North America, centred on the paradigm advocated by the private sector of the need to pair security with prosperity. It was also the first time that Canada and Mexico obtained take-up from the National Security Council on the need to link a security agenda with a prosperity agenda. The three governments agreed that the NAI would be used as the basis for developing a model that would identify a number of areas where incremental progress could be achieved in

\footnotetext{
${ }^{189}$ Confidential interview with a former official at the Privy Council Office, dated 2007-09-19.

${ }^{190}$ Confidential interview with a United States Government Official, dated 2007-12-13.

${ }^{191}$ Confidential interview with a former official at the Privy Council Office, dated 2007-08-14.
} 
the Canada-U.S. relationship, the U.S-Mexico relationship, and the trilateral relationship; a model that would add encouragement from the political level to ongoing workaday cooperation. ${ }^{192}$ This encouragement from the political level would help to remove obstacles to progress on incremental initiatives that would otherwise face logjams in the absence of engagement from the political leadership and the central agencies that support them. This perpetuation of a management-from-the-centre framework was a unique consideration of government actors in the policy community. It was generated by the success of managing the bilateral security relationship from the centre of government under Smart Borders and the Alianza para la Frontera.

All three governments coalesced around the adoption of the Canadian vision of aggressive incrementalism, as opposed to bigger visions for a common security perimeter or a customs union. The decision to embrace a more incremental pace and sequence coincided with the consensus that had emerged in the private sector by the time that the Independent Task Force on the Future of North America had released its report. That being said, the three governments never reached the level of agreement on the contents for this new framework that came anywhere close to resembling what many private sector actors in the policy network were advocating. The failure to incorporate the Big Visions favoured by the private sector on the NAI agenda is explained by the fact that several variables in the policy stream presented insurmountable obstacles to adopting those particular policy options.

The proposals for a customs union and common security perimeter were not technically feasible. The common security perimeter would have required unprecedented levels of cooperation between security agencies in all three countries. Both Canadian and

${ }^{192}$ Confidential interview with a former official at the Privy Council Office, dated 2007-10-03. 
American officials pointed to the difficulties inherent in such an arrangement. In particular, it was impossible to achieve substantial trilateral cooperation on common approaches to security, given the capability gap that exists between Mexico and its North American partners. For example, Canadian and American law enforcement officers participate in Integrated Border Enforcement Teams (IBET) along the Canada-U.S. border, but this sort of cooperation could never be trilateralized, much less replicated along the southern border, because of the divergence in ethos, training, and cultures. ${ }^{193}$ As U.S. Assistant Secretary of State Roger Noriega told the Senate Foreign Relations Committee, "Institutional underdevelopment and corruption of state and local law enforcement officials are serious challenges" in the security relationship with Mexico. ${ }^{194}$ At a broader level, there was a very significant difference in the way that the U.S. manages its two borders. Along the southern border, the United States had adopted the policy stance that hardening the border was the appropriate response to stem the flow of drugs and migrants from Mexico. In contrast, officials in Washington had been quite receptive to the idea of leveraging new technology in a risk-based approach to the northern border. Given this dichotomy, the difficulty for the United States in moving to a harmonized 'smart border' approach across the continent, was that it would force Americans to reconsider their approach to interdicting drugs and migrants along the southern border. ${ }^{195}$ In addition, Canadian officials were intensely opposed to any attempt to harmonize America's two border policies.

\footnotetext{
${ }^{193}$ Confidential interview with a former official at the Privy Council Office, dated 2007-09-06.

${ }^{194}$ United States, Senate, Committee on Foreign Relations, United States and Mexico: Immigration Policy and the Bilateral Relationship, $108^{\text {th }}$ Cong., $2^{\text {nd }}$ Sess., 23 March 2004, 50.

${ }^{195}$ Flynn, "The False Conundrum-Continental Integration vs. Homeland Security," in The Rebordering of North America, 124.
} 
Another technical barrier to the pursuit of a common security perimeter was that Mexico lacked the capacity required to effectively contribute to a security perimeter. Mexican security cooperation with the United States was a very new and under-developed endeavour. ${ }^{196}$ Mexican and Canadian security agencies had virtually no contact. One Mexican security official acknowledged that, prior to the SPP there was very little knowledge of the roles and responsibilities of security agencies in Canada. ${ }^{197}$ It was only as a result of the SPP that security agencies in the two countries became acquainted; it even took until August 2007 for the establishment of a Canada-Mexico Bilateral Security Working Group. ${ }^{198}$

There were also technical barriers to moving forward with the proposal for a customs union. The NAFTA working groups were encountering difficulties when it came to completing their agendas. ${ }^{199}$ In addition, no groundwork had been laid in recent years for discussion of other NAFTA-related issues that would require work prior to implementing a customs union, such as liberalizing trade in agricultural goods. A full fledged custom union would have required the adoption of a common external tariff across all sectors; in the textile and agricultural sectors, where tariff and non-tariff barriers remained high, adoption of a common external tariff would have been extremely difficult. $^{200}$ The feasibility of a trilateral customs union was also unlikely given the economic development gap that existed between Mexico and its two continental partners.

\footnotetext{
${ }^{196}$ See Chapter 1, pages 38-40; 42.

${ }^{197}$ Confidential interview with an official at Secretaría de Gobernacion, dated 2007-09-27.

${ }^{198}$ Canada, Department of Foreign Affairs and International Trade, "Canada and Mexico: A Joint Action Plan for 2007-2008," (Ottawa: August 21, 2007), http://www.dfait-maeci.gc.ca/mexico-city/news/ Bilateral\%20Action\%20Plan\%20final\%2020aug-en.pdf. 199 See Chapter 1, pages 33-34.

${ }^{200}$ The complement to a common external tariff was the requirement for the three countries to harmonize their trade policy, which would have affected other sensitive areas such as trade remedy law and customs
} 
Obstacles to pursuing a customs union and security perimeter also existed with respect to perceptions of values acceptability. In the multiple streams model, values acceptability can be approximated through the perception of public acquiescence and the attitude of lawmakers towards a customs union or common security perimeter. One indicator of the sensitivity of policy actors to the public mood was the decision in all three countries to turn to their economy ministries, rather than their trade ministries, to manage the prosperity pillar of the NAI. ${ }^{201}$ Given the protectionist mood on Capitol Hill, the Bush Administration was adamant that the NAI had to be designed in such a manner that it could ride above Congress. ${ }^{202}$ Since international trade fell within the jurisdiction of the legislative branch, it was felt that the involvement of United States Trade Representative would simply be a lightening rod for attracting unwanted Congressional attention. $^{203}$

In Canada, there was reluctance to frame the NAI as a trade instrument. Around the Cabinet table, there was considerable political sensitivity about creating the appearance that the SPP was "NAFTA-Plus." The Martin Cabinet had no appetite for a debate on re-opening NAFTA and ministers sensed that the public would not tolerate a NAFTA-Plus with the United States. The Cabinet was more interested in framing the policy debate around the subject of moving to the next generation of the Smart Border

procedures [André Downs, "North American Integration: Challenges and Potential Responses," in Horizons 7 , no. 1 (June 2004), 6].

${ }^{201}$ The three economy ministries were: Industry Canada, the U.S. Department of Commerce, and Secretaría de Economía.

${ }^{202}$ See Chapter 4, pages 97-99.

${ }^{203}$ USTR was involved in the early discussions on the North American Initiative. However, after it became clear that the NAI would not substantively address the NAFTA agenda or trade disputes, USTR ceased its involvement in the process [Confidential interview with an official at the Department of Foreign Affairs and International Trade, dated 2007-10-02]. 
Declaration. ${ }^{204}$ As one senior civil servant in Ottawa explained, "There was recognition in government that Canada has NAFTA, that we have the NAFTA working groups, and that Canada is not going to re-open NAFTA." ${ }^{205}$ The best way for Canadian Ministers to control this message was to maintain distance between International Trade Canada and the SPP.

In the United States, there was even less receptivity to the option of pursuing a common security perimeter. As a result of the growing debate over immigration reform in the U.S., new groups emerged that sought to pressure Washington to harden the border with Mexico. ${ }^{206}$ A common security perimeter was also opposed by libertarian groups who feared that it would undermine America's political values. ${ }^{207}$ These groups automatically linked any discussion of a customs union or common security perimeter to their conspiracy theories about the creation of a North American Union. This fear of the creation of a North American Union was captured in the rhetoric of the "Lou Dobbs crowd." Inspired by the CNN television pundit, adherents complained about the lingering effects of NAFTA and the impact of globalization on American jobs. Dobbs' supporters were inspired by catchphrases such as the "exporting of America," or fixing "America's broken borders." 208 One U.S. official remarked that American politicians were surprised

\footnotetext{
${ }^{204}$ Confidential interview with a former Canadian Parliamentarian, dated 2007-09-04.

${ }^{205}$ Confidential interview with a former official at the Privy Council Office, dated 2007-09-05.

${ }^{206}$ Groups such as the Minutemen Project had become increasingly vocal about the threat posed by the growing presence of migrant Mexicans in the United States. For example, see: Stop SPP.Com, http://stopspp.com/stopspp/

${ }^{207}$ For example, the John Birch Society alleges that the SPP is a prelude to a common perimeter or customs union that would undermine the sacred American constitutional principles of limited government and personal freedom. The Society claims that over fourteen state legislatures have passed resolutions condemning the North American Union [John Birch Society, Position Statement, "North American Union \& Security and Prosperity Partnership," http://www.jbs.org/node/915].

${ }^{208}$ In June 2006, Dobbs provided the following assessment of the SPP: “The Bush Administration's openborders policy and its decision to ignore the enforcement of this country's immigration laws is part of a broader agenda. President Bush signed a formal agreement that will end the United States as we know it, and he took the step without approval from with either the U.S. Congress, or the people of the United
} 
at the degree of passion of the anti-NAFTA crowd. ${ }^{209}$ With this sort of opposition to anything resembling a North American Union, a powerful constraint was placed on what could be achieved.

In Canada, there was a similar appreciation of the lack of public support for any policy option that involved a customs union or common security perimeter. Early on, Prime Minister Chrétien rejected the concept of 'perimeter security,' which American Ambassador Paul Cellucci had called a "no brainer," in part because of the potential constraint this would place on Canada's ability to legislate its own immigration and refugee laws. ${ }^{210}$ In response to the North American Security and Prosperity Initiative proposed by the Canadian Council of Chief Executives, Maude Barlow and the nationalist Council of Canadians (CoC) launched its Deep Integration campaign in 2003. ${ }^{211}$ As part of the campaign, the $\mathrm{CoC}$ conducted its own cross-Canada consultations, hosting town hall meetings across the country to discuss the future of the Canada-U.S. relationship. The results of these consultations were published in a blistering attack on North American integration, called Colony or Country? ${ }^{212}$ The Council's publications and town hall meetings had the potential to touch a nerve with Canadians who were growing increasingly sceptical of the policies of the Bush Administration. ${ }^{213}$

\footnotetext{
States." [CNN.com, Transcripts, Lou Dobbs Tonight, Aired 2006-06-21, http://transcripts.cnn.com/ TRANSCRIPTS/0606/21//dt.01.htm].

${ }^{209}$ Confidential interview with a United States Government Official, dated 2007-12-13.

${ }^{210}$ Hristoulas, "Trading Places: Canada, Mexico, and North American Security," in The Rebordering of North America, 35.

${ }^{211}$ The Council defines "Deep Integration" as any economic policies that erode Canadian sovereignty and make it difficult or impossible to tailor economic policy to meet distinctly Canadian needs [Confidential interview with an official from the Council of Canadians, dated 2007-10-02].

${ }^{212}$ See: Council of Canadians, Crossing the Line: A Citizen's Inquiry on Canada-U.S. Relations, (Ottawa: The Council of Canadians, 2005).

${ }^{213}$ See Chapter 4, pages 100-101.
} 
A shortage of available resources imposed a further constraint on adopting any content-driven initiatives in the policy stream. In both the United States and Mexico, the budget served as a constraint for policy actors since it limited the potential resources that were available for pursuing a content-driven initiative for North America. ${ }^{214}$ While private sector actors in the policy community paid little heed to resource implications when developing their policy options, government actors in the policy network did not enjoy this luxury. Accordingly, the process-centric NAI model was a much better fit for government actors, since it mostly re-packaged ongoing and largely workaday bilateral initiatives; the new resources required to support the NAI were minimal.

\subsection{Structuring the NAI Agenda}

The softening up process was facilitated by the fact that, as of March 2003, a high level network of central agency officials had begun to exchange views and build consensus around the architecture and content of the NAI model. At the highest levels, senior coordinators in the three central agencies-Alberto Ortega, Faryar Shirzad, and Phil Ventura-spoke frequently with one another. The involvement of senior central agency officials was critical for building a framework capable of identifying and elevating ongoing technical initiatives that were in need of support from senior ministers and the three national leaders.

When the NAI discussions began in earnest, the task of defining a trilateral security and prosperity agenda was terra incognita. The adoption of the managementfrom-the-centre framework permitted the emergence of new interagency processes in each country dedicated to evaluating and debating potential policy initiatives for inclusion

${ }^{214}$ See Chapter 1, pages 48-50. 
on the NAI agenda. In Canada, Ventura chaired a committee of line department Assistant Deputy Ministers. This committee was responsible for preparing a list of Canadian "asks" for initiatives to be included on the NAI agenda. The Canadian asks list was formulated by a series of inter-departmental working groups that were organized around specific policy sectors. ${ }^{215}$ As part of the consensus building process, each working group was supposed to consult with its stakeholder community, although it was impossible for PCO officials to measure the extent to which these consultations actually occurred. ${ }^{216}$ The Canadian asks list was taken to trilateral meetings with the American and Mexican central agency coordinators for approval. ${ }^{217}$ In the United States, a similar interagency process existed under the aegis of the Policy Coordinating Committees of the NSC.

The management-from-the-centre process worked well. In fact, one Canadian official could not recall any initiatives of the Canadian interdepartmental process that were dropped at the trilateral level. ${ }^{218}$ The existence of dedicated interagency networks in each country linked by central agency coordination was instrumental in disseminating and debating proposals for inclusion on the NAI agenda. By incorporating senior and midmanagement departmental officials from all three countries at the working group level, consensus was easily reached among government participants on the menu of ongoing policy initiatives submitted for their consideration.

For central agencies, combining ongoing policy initiatives under a single umbrella created the necessary pressure to force line departments to make progress on bilateral

\footnotetext{
${ }^{215}$ In the lead up to the Waco Summit and Ottawa Ministerial, these internal working groups became trilateral working groups that examined each country's "asks" in each policy sector. The trilateral working groups set the agenda for their sector and submitted this agenda to the trinational coordinator's meeting for approval [Confidential interview with a former official at the Privy Council Office, dated 2007-10-03].

${ }^{216}$ Confidential interview with a former official at the Privy Council Office, dated 2007-11-06.

${ }^{217}$ Confidential interview with a former official at the Privy Council Office, dated 2007-10-03.

${ }^{218}$ Ibid.
} 
initiatives that had stalled. This pressure was created because of the short time frames to produce deliverables that had to be periodically reported to leaders and ministers and because of the absence of new money. ${ }^{219}$ The absence of new funding and the pressure to take stock of departmental initiatives left departmental officials with little choice but to identify ways of correcting program inefficiencies for initiatives selected as SPP deliverables. ${ }^{220}$ For line departments, the NAI provided an opportunity to generate attention for largely technical initiatives that would normally fall below the political radar.

Canada's Privy Council Office assumed the lead role for developing the NAI agenda. In light of Canada's experience with Smart Borders, there was little doubt that repackaging existing initiatives was effective. As one former PCO official described, "Smart Borders had a reputation for giving oxygen to existing ideas that had run into roadblocks prior to $9 / 11 ., 221$. When developing content for the NAI agenda, the basic pitch from the PCO to line departments across Ottawa was an appeal to identify ongoing bilateral initiatives that could benefit from direct engagement between the PCO and the White House. ${ }^{222}$ Consultations were held with line departments across Ottawa between 2003 and 2004. The PCO set the following general criteria: issues where long-standing informal discussions had already been occurring between Canadian and American officials, but that were lacking deliverables; issue-areas where formal cooperative mechanisms already existed, such as Smart Borders or the North American Energy Working Group; and areas where there was already an agenda and ongoing work, such as

\footnotetext{
${ }^{219}$ Confidential interview with an official at the Department of Transportation, dated 2007-12-14. ${ }^{220}$ Ibid.

${ }^{221}$ Confidential interview with a former official at the Privy Council Office, dated 2007-09-06.

${ }^{222}$ Ibid.
} 
the NAFTA working groups. ${ }^{223}$ Just like the Smart Borders Declaration, the idea was to repackage initiatives into a new framework that could be used to generate progress.

A similar process occurred in the United States, where the National Security Council asked departmental and agency officials to identify the "low hanging fruits" so that leaders could quickly show they are making progress on existing initiatives. ${ }^{24}$ The decision to focus on re-packaging ongoing initiatives created space to avoid questions of technical feasibility and skirt around public reticence over deepening integration. Since there were very few new initiatives contained in the NAI, the resource costs were minimal since most of these initiatives drew on existing appropriations.

The process of re-packaging ongoing initiatives was similar to the process of recombination contained in the multiple streams model. The intention of the three governments to recast their ongoing security cooperation was communicated in an implementation memorandum issued by the Department of Homeland Security:

DHS-led U.S.-Canada and U.S.-Mexico groups already in existence will take on the SPP actions within their scope. Moreover, in several cases, new groups will need to be established. That said, the SPP has, in addition to identifying a number of new action items, comprehensively rolled up most of our existing homeland securityrelated initiatives with Canada and Mexico, and ongoing action and reporting in the various U.S.-Canada and U.S.-Mexico working groups led by DHS should now be driven by a single agenda: the SPP. Henceforth, any U.S.-Canada or U.S.-Mexico briefing materials should-instead of referring to pre-existing action items-refer to the SPP agenda. ${ }^{225}$

The SPP Work Plan that was announced at the Ottawa Ministerial contained numerous examples of recombination. With respect to the security pillar, the agenda was structured on a dual bilateral basis. For example, the two bilateral SPP Law Enforcement Working

\footnotetext{
${ }^{223}$ Confidential interview with a former official at the Privy Council Office, dated 2007-10-03.

${ }^{224}$ Confidential interview with an official at the Department of Transportation, dated 2007-12-14.

${ }^{225}$ Judicial Watch, Freedom of Information Act Request, "Memorandum from Secretary Chertoff, Re: Implementation of Security and Prosperity Partnership," 22 September 2005, http://www.judicialwatch.org/ archive/2007/dhs06-880reSPP14Mar07_001.pdf.
} 
Groups built on pre-existing networks. The Canada-U.S. working group drew on the strong cooperation that already existed between law enforcement agencies in the two countries. It also built on the dialogue that occurred in other forums that pre-dated the SPP, such as the Canada-U.S. Cross Border Crime Forum, to the point where a degree of overlap existed. ${ }^{226}$

In some instances re-combination even served as a constraint. For example, the SPP Intelligence Cooperation working group was befuddled by the challenge of defining a mandate for itself. As explained by an official at Canada's Department of Public Safety, this challenge existed precisely because bilateral intelligence cooperation had existed between Canada and the United States since the Second World War. ${ }^{227}$ Given the unique cultures of intelligence organizations, it was difficult for those officials to find the value added in creating a new SPP working group. Consequently, there had to be a renegotiation of the terms of reference for the group that shifted its mandate from an intelligence sharing logic to an intelligence supporting logic. ${ }^{228}$ The most compelling evidence that the NAI agenda demonstrated a process of recombination is that virtually all of the Smart Borders Declaration and Alianza para la Frontera deliverables can be found under the SPP theme of "Smart and Secure Borders."

While the proposals for a common security perimeter encountered significant difficulties in the policy stream, re-packaging existing security initiatives under a new

\footnotetext{
${ }^{226}$ Confidential interview with an official at Public Safety Canada, dated 2007-09-18. With respect to the United States and Mexico, the SPP Law Enforcement Working Group was cited as one of the most successful of the SPP working groups because it built on dialogue and institutional relationships that were already well developed as a result of each country's participation in the annual U.S.-Mexico Senior Law Enforcement Plenary [Confidential interview with an official at Secretaría de Gobernacion, dated 2007-0927].

${ }^{227}$ Confidential interview with officials from Public Safety Canada, dated 2007-09-18.

${ }^{228}$ The SPP Intelligence Working Group can now be used to exchange intelligence assessments in a way that allows each country to talk about common problems in the context of identifying good ideas and mechanisms used by the other country to address specific problems [Ibid].
} 
SPP narrative was relatively simple exercise since it merely extended previous government commitments. In Canada, Smart Borders was well regarded by Cabinet and officials at the Privy Council Office. One of Canada's biggest negotiating priorities at the 2005 SPP Ministerial was to ensure that trusted traveler programs and border security programs were moved forward under the SPP. ${ }^{229}$ In the United States, the entrenchment of the Smart Borders paradigm was consistent with Congressional priorities and the Customs Trade Partnership Against Terrorism (C-TPAT). In fact, two of C-TPAT's centerpiece programs were Smart Borders and the Alianza para la Frontera. ${ }^{230}$ In many respects, re-packaging security initiatives proved to be the path of least resistance for identifying NAI content that could survive the constraints of the policy stream.

In contrast to the security pillar, many of the prosperity deliverables were trilateral. One prosperity working group, the SPP Environment Working Group, borrowed significantly from the agenda of other trilateral forums in order to structure its agenda. One of the group's deliverables - developing an ecosystems approach for oceans stewardship—complemented the ongoing work of the Council for Environmental Cooperation. ${ }^{231}$ A second example of recombination is found in the decision to include

\footnotetext{
${ }^{229}$ Confidential interview with a former Parliamentarian, dated 2007-09-04.

${ }^{230}$ The SPP was consistent with the multi-layered security program manifest in the U.S. Customs-Trade Partnership Against Terrorism (C-TPAT). C-TPAT is designed to push America's zone of security outwards, so that the first line of defence starts in factories abroad and the last line is the American border. U.S. Customs and Border Patrol (CBP) Commissioner Bonner told Congress that partnering with Canada on FAST and NEXUS under Smart Borders, and with Mexico through SENTRI, is a complement to CTPAT and the Container Security Initiative, all programs designed to voluntary engage the private sector in securing supply chains long before cargo reaches the U.S. border [United States, House of Representatives Select Committee on Homeland Security, Balancing Security and Commerce: Hearing Before the Subcommittee on Infrastructure and Border Security, $108^{\text {th }}$ Cong., $1^{\text {st }}$ Sess., 16 June 2003, 11-13].

${ }^{231}$ Environment officials had already worked on: (1) the establishment of Marine Protected Areas along the Mexican coast; (2) the management and elimination of toxic substances from use in North America as part of the Commission for Environmental Cooperation agenda. The Environment Working Group also provided the high level attention required to generate momentum for the signing of a Declaration of Intent for the Conservation of North American Birds and Their Habitat, which originated in the work of a different forum, the Trilateral Committee for Conservation of Wildlife [Commission for Environmental Cooperation,
} 
the agenda of the North American Energy Working Group (NAEWG) under the SPP framework. ${ }^{232}$ In both instances, recombination allowed the SPP to do precisely what the NAI model had intended: to raise largely workaday and technical issues to the periodic attention of the three leaders, in order to generate forward momentum.

The use of the SPP framework to elevate workaday issues is evident in the transportation-infrastructure agenda of the SPP Transportation Working Group. ${ }^{233}$ An official at Transport Canada remarked that the SPP did not create any new deliverables, but rather served as a catalyst for raising the profile of the work done at the Canada-U.S. Transportation Border Working Group by bringing it to the attention of high level officials. $^{234}$ His counterpart at the U.S. Department of Transportation produced a similar assessment, indicating that, at best, the SPP served to accelerate progress on initiatives that were already under discussion, such as the Open Skies Agreement or the infrastructure upgrades at the Detroit-Windsor border. ${ }^{235}$

As a potentially resource-intensive policy sector, the transportation-infrastructure agenda exemplified how re-packaging initiatives could deliver results within the constraints imposed by the policy stream. For example, American officials expressed an

\footnotetext{
"North American Marine Protected Areas Network," http://www.cec.org/programs_projects/conserv_ biodiv/ project/index.cfm?projectID=19].

${ }^{232}$ The NAEWG was announced by the three leaders in April 2001. It functions as a discussion forum for energy officials from the three countries. Initially, there was some problems attendant to the NAEWG. One Canadian official described the forum as being, "big on ideas, but short on substance." The U.S. Department of Energy was not a great interlocutor for Canadian officials. It was described as an example of a trilateral group that suffered from being run on a department-to-department basis, rather than driven from the centre [Confidential interview with a former official at the Privy Council Office, dated 2007-0906].

${ }^{233}$ For example, the Canada-U.S. deliverables of the SPP Transportation Working Group drew on the work of a pre-existing group, the Transportation Border Working Group (TBWG). For example, one SPP deliverable required the TBWG to produce an online compendium of border crossing data.

${ }^{234}$ Confidential interview with an official at Transport Canada, dated 2007-11-30.

${ }^{235}$ Confidential interview with an official at the U.S. Department of Transportation, dated 2007-12-14.
} 
interest in integrating North American transportation networks. ${ }^{236}$ Instead of announcing a new North American Investment Fund to fund transportation projects, recasting existing initiatives under the SPP allowed officials to pursue similar objectives by re-constituting the objectives of previously approved appropriations. ${ }^{237}$ Re-packaging the objectives of infrastructure programs that had already received legislative approval allowed government officials to bypass potential constraints to improving North America's transportation infrastructure from a public reluctant to accept any initiative that resembled deeper North American integration.

Despite the emphasis on recombination for explaining the content development of the security and prosperity pillars of the North American Initiative, this analysis would be incomplete if it did not assess the rise of "new initiatives" for inclusion on the NAI agenda. The SPP work plan provided examples of new initiatives, such as the creation of a working group on emergency management and the development of a North American avian and influenza pandemic preparedness plan. ${ }^{238}$ Both of these initiatives, however, were cost effective and were not calculated to arouse public angst. ${ }^{239}$ In contrast, the

\footnotetext{
${ }^{236}$ U.S. Assistant Secretary of State for Economic Affairs told the Senate Foreign Relations Committee in 2004, "We need to look closer at infrastructure constraints as trade continues to increase." He pointed to greater improvement and integration in road, rail and aviation systems, such as North American Open Skies, objectives which he saw NAFTA as promoting [United States, Senate Committee on Foreign Relations, "NAFTA A Ten Year Perspective and Implications for the Future: Hearing before the Subcommittee on International Economic Policy, Export, and Trade Promotion, $108^{\mathrm{h}}$ Cong., $2^{\text {nd }}$ Sess., 20 April 2004, 19]. Mexico has a strong interest in constructing new transportation infrastructure to connect underdeveloped regions of Mexico to NAFTA trade corridors.

${ }^{237}$ The Canadian and American legislatures had authorized large transportation appropriations for the years during which the NAI was being developed. For example, the U.S. Congress passed the Transportation Act for the $21^{\text {st }}$ Century, which authorized US $\$ 217$ billion through 2003 and the Intermodal Surface Transportation Efficiency Act which allocated US $\$ 150$ billion over six years. In February 2000, the Canadian Parliament approved $C \$ 400$ million for strategic highway infrastructure beginning in 2002. [Pastor, Toward a North American Community, 106].

${ }_{238}$ In 2007 , the emergency management working group became the North American Emergency Management Council. Work on the North American Avian and Influenza Pandemic Plan was first announced at the 2006 Cancun summit, though it was officially presented at the 2007 Montebello Summit. ${ }^{239}$ Even today, the civil society critique is focused on the creation of the North American Competitiveness Council and the Regulatory Cooperation Framework, rather than on these more workaday initiatives.
} 
Regulatory Cooperation Framework, a hallmark of the SPP prosperity agenda, had the potential for encountering difficulty in the policy stream.

The ability of the Regulatory Cooperation Framework to survive the constraints imposed by the policy stream can be attributed to the softening up process that preceded it. The groundwork was laid by an independent panel appointed by Prime Minister Jean Chrétien in May 2003 to study Canada's regulatory regime. The External Advisory Committee on Smart Regulation issued its report in September $2004{ }^{240}$ The report identified the problem that, in many instances, there were minute regulatory differences that existed between Canada and the U.S., even though regulators in the two countries often shared the same regulatory objectives. For this reason, the Panel recommended that Canada move toward a North American standard in any instance where regulatory convergence would make the Canadian economy more efficient, while providing high levels of protection for health and the environment. ${ }^{241}$

The panel's recommendation was accompanied by substantial softening up in the policy stream: organized business groups, such as the CCCE, included the need for regulatory harmonization in their policy proposals for North America. ${ }^{242}$ Think tanks and individual academics issued studies identifying the need for regulatory convergence. ${ }^{243}$ The Independent Task Force on the Future of North America also called for the adoption

\footnotetext{
${ }^{240}$ The report was intended to position the government to use the regulatory system to promote an innovative and competitive economy, while balancing that objective with the pursuit of social and environmental regulatory aims. The Panel recommended that for all new regulations, the Government should look to a North American standard, except in cases when Canadian values or constitutional requirements are at risk, when no North American or international standard exists, or where there is no confidence in the regulatory practices of the trading partner [Canada, External Advisory Committee on Smart Regulation, Smart Regulation: A Regulatory Strategy for Canada (Ottawa: September 2004), 25]. ${ }^{241}$ Canada, Smart Regulation: A Regulatory Strategy for Canada, 22-23.

${ }^{242}$ Canadian Council of Chief Executives, "Security and Prosperity: Toward a New Canada-United States Partnership in North America," (Ottawa: January 2003), 1.

${ }^{243}$ See William Dymond and Michael Hart, Common Borders, Shared Destinies, 13; Council of the Americas, A Compact for North American Competitiveness, 1 ; Conference Board of Canada, In Search of a New Equilibrium in the Canada-U.S. Relationship, 2.
} 
of a North American approach to regulation. ${ }^{244}$ The Task Force recommended that the three governments identify priority sectors for immediate action and establish a "tested once" principle for biotechnology and pharmaceuticals.

Broad support for regulatory cooperation existed among both government and private sector actors in the policy community. At the 2003 conference organized by the Public Policy Forum, one of the NAI's architects, Jonathan Fried, spoke of the need to pursue regulatory reforms. ${ }^{245}$ In October 2004, the government-sponsored Policy Research Initiative hosted a conference to study the External Advisory Committees' findings; the conference was attended by Canada's NAI coordinator, Phil Ventura, who endorsed the proposal to identify priority areas on which to focus immediate attention. ${ }^{246}$ Ventura continued the softening up process at the April 2005 meeting of the Can-Am Border Trade Alliance, where he underscored the need for the three countries to move toward regulatory harmonization in order to remove "differences that make no difference. ${ }^{247}$ With senior government officials committed to softening up a stakeholder community that largely shared its viewpoint on the need for regulatory convergence, the Regulatory Cooperation Framework had significant momentum in the policy stream to justify its inclusion as a long run deliverable when populating the NAI agenda.

The traction of the Regulatory Cooperation Framework can once again be approximated by applying the now familiar variables of technical feasibility, values acceptability, and tolerable resource costs. Potential technical obstacles were averted by

\footnotetext{
${ }^{244}$ Independent Taskforce on the Future of North America, Building a North American Community, 24-25. ${ }^{245}$ The Public Policy Forum, Rethinking North American Integration, Conference Report, (29-30 October 2003), http://www.ppforum.ca/common/assets/publications/en/na_outcomes_final.pdf.

${ }^{246}$ Canada, Policy Research Initiative, Canada-U.S. Regulatory Cooperation Symposium Report, (Ottawa: 29 October 2004), http://www.policyresearch.gc.ca/doclib/NAL_SR_reg\%20coop\%20CanadaUS_200410_e.pdf.

${ }^{247}$ Can-Am Border Trade Alliance, "April 2005 Ottawa Conference Summary Highlights," (Ottawa: 24-25 April 2005), http://www.canambta.org/ott_2005_summary1.pdf.
} 
the decision to pursue a gradual approach to regulatory convergence. Government officials understood that the setting of the regulatory agenda had to be done on a North American basis from the bottom up. ${ }^{248}$ The test that was used for selecting which regulatory initiatives would be included under the Framework was to pose the question: "Was there a common view within each country's regulatory community that the three countries can agree on?"249 In order to set the regulatory agenda, policy actors had to take stock of items across all industries that could lead to improved trade facilitation. ${ }^{250}$ In addition, studies had already been completed on the feasibility of regulatory convergence. $^{251}$ With respect to acceptability to lawmakers, regulatory authority fell within the exclusive purview of the Executive Branch in each country. This permitted departments across the three countries to pursue the regulatory agenda without requiring the approval of the national legislatures. This also meant the Regulatory Cooperation Framework would not be scrutinized until after the announcement of the SPP. ${ }^{252}$ Even though there was a fair amount of public discontent with the framework, it surfaced too late to derail the Regulatory Cooperation Framework in the policy stream.

\footnotetext{
${ }^{248}$ Confidential interview with a former official at the Privy Council Office, dated 2007-08-14.

${ }^{249}$ Confidential interview with a former official at the Privy Council Office, dated 2007-08-14. ${ }^{250}$ Ibid.

${ }^{251}$ See André Downs, "North American Integration: Challenges and Potential Responses," in Horizons 7, no. 1 (June 2004): 4-8; Michael Hart, "Steer or Drift? Taking Charge of Canada-U.S. Regulatory Convergence," C.D. Howe Institute, The Border Papers, no. 229 (March 2006).

${ }^{252}$ The Regulatory Cooperation Framework first appeared in the June 2005 SPP Report to Leaders, although it was not formally announced until the 2007 North American Leaders' Summit in Montebello. The Canadian Centre for Policy Alternatives published a paper that argued that weakened industrial chemicals regulations would put the public at risk [Bruce Campbell, "More than Jellybeans: The SPP Regulatory Framework Agreement and its Impact on Chemical Regulations," Canadian Centre for Policy Alternatives North American Deep Integration Series 1, 1 (September 2007), http://www.policyalternatives.ca/documents/National_Office_Pubs/2007/More_Than_Jellybeans.pdf ]. The Public Service Alliance of Canada, the union that represents Canadian civil servants, also expressed concern that regulatory harmonization would result in lost jobs for the civil service [Confidential interview with an official from the Council of Canadians, dated 2007-10-02]. The Canadian Labour Congress alleged regulatory cooperation would increase the power of corporations, promote de-regulation, import lax American regulations and standards [Teresa Healy, "Deep Integration in North America: Security and Prosperity for Whom?”, Canadian Labour Congress, Research Paper \#42 (20 February 2007), ii.].
} 
The policy stream was instrumental in shaping the ultimate design of the security and prosperity framework. Within the government sector of the policy community, the North American Initiative became the policy alternative with the most traction. The architecture created by the NAI - a framework that entrenched the co-dependency of security and prosperity, the two-speed model for the inclusion of Mexico, and the management-from-the-centre arrangement for prioritizing ongoing initiatives-coincided with the consensus that had emerged from private sector members of the policy community.

While consensus was reached in the policy stream with respect to the architecture of the model for a new North American initiative, a divergence between the public and private sectors remained over the contents of this new policy option for North America. After a prolonged period of policy debate and softening up, it became clear that technical barriers, lukewarm acceptance from the public and lawmakers, and intolerable resource costs would preclude filling the new policy model with Big Vision initiatives. Instead, the NAI model came to be structured by ongoing policy initiatives that reflected the process of recombination. In contrast to the Big Vision initiatives, these agenda items did not encounter the same technical barriers, public resistance or intolerable resource costs. This process of diffusion and consensus-building in the policy stream explained the emergence of an incremental process-driven initiative as the favoured policy alternative for the management of the North American relationship. The NAI survived the policy soup and was ready to be paired with developments in the politics and problem streams. 


\section{CHAPTER 4: THE POLITICS STREAM}

One of the most potent explanations for the decision of the three governments to pursue a process-driven initiative is found in the politics stream of the multiple streams model. By applying the framework provided by the politics stream, this chapter will analyze the political conditions that structured the government agenda between 2001 and March 2005. The contours of this agenda provided several opportunities for the SPP to move from the policy backburner to the top of each government's agenda in all three countries.

\subsection{The Politics Stream in the Multiple Streams Model}

The political stream is useful for identifying the political conditions that made the movement of the SPP to the top of the structured agenda in each country possible. While the process of alternative specification in the policy stream occurs in a secluded state, the politics stream introduces the constraint of political pragmatism. That is, the politics stream is useful for identifying what policy options were permissible given the prevailing political climate. The determination of what policy options are politically feasible is contingent on four variables: national mood, the electoral cycle, turf battles, and the balance of organized political forces. The first two variables are especially important for structuring the government agenda, while the latter two variables are critical for securing the place of a policy option on the structured government agenda.

The first variable, national mood, refers to very broad and general changes in public attitudes. The national mood serves as a filter for determining which proposals can 
obtain a serious hearing from decision-makers. ${ }^{253}$ Since these are "big picture" changes, the national mood is difficult to derive from public opinion polls. Rather politicians perceive the national mood from having their 'ear to the ground,' listening to representations from interest groups, reading newspaper editorials, reading constituent mail, and attending town hall meetings. ${ }^{254}$ The structure of the government agenda in each of the three countries is also determined by the interests and priorities of the political appointees that come to office with the election of the head of government. ${ }^{255}$ In all three countries, the electoral cycle has a critical role to play. In order to ensure that a policy option remains on the government agenda, it helps to have the right mix of decision makers appointed to powerful positions in government.

Even if the national mood is receptive, and the slate of elected officials is sympathetic, a policy initiative is far from guaranteed a place on the government agenda. One potentially complicating factor for the rise of a policy option in the politics stream is that it could become hostage to internecine turf battles between the different branches of government, or between the various agencies and departments of the Executive Branch. These turf battles can affect agenda change in two ways: either the issues are ignored because they are "defined away" in battles of jurisdiction, or jurisdictional overlap could instigate competition to control the agenda item, generating faster movement than would otherwise occur. ${ }^{256}$ Even if all the conditions in the politics stream align in favour of a particular policy alternative, a successful round of coalition building must occur in order to secure a place for the policy alternative at the top of the government agenda. If the

${ }^{253}$ Kingdon, Agendas, Alternatives, and Public Policies, 146-147.

${ }^{254}$ Ibid., 148-149.

${ }^{255}$ In the United States and Mexico, these appointees were Cabinet and sub-Cabinet officials. In Canada, there is a professional and apolitical civil service. The appointments that mattered in Canada concerned the portfolio appointments of Cabinet ministers and any Cabinet committee chairmanships they receive.

${ }^{256}$ Kingdon, Agendas, Alternatives, and Public Policies, 158. 
balance of political forces-the organized political interests in and around governmentare lined up in support of a policy, it can be a very powerful impetus for policy change. ${ }^{257}$ If decision-makers take stock of the balance of supporting and opposing forces and perceive an uphill battle, it may preclude the advancement of a particular policy proposal. ${ }^{258}$ Accordingly, agenda change will occur whenever the constitution of political forces changes. The best time for coalition building is when an "air of compromise" exists. $^{259}$ This bandwagon effect can be a very powerful impetus for agenda change, since it creates a generalized image of movement for the policy option. ${ }^{260}$ In the context of the SPP, the major arena for coalition building was between the government and the private sector, generating the momentum needed to position the Security and Prosperity Partnership as a politically feasible option on the governments' agendas.

\subsection{The National Mood}

The menu of policy alternatives for the future of North American integration was shaped by the fact that politicians perceived that the public was not yet ready to embrace proposals for a customs union or common security perimeter. In the United States, there was very little public appetite for any policy alternative that resembled a trade agreement. This prevailing mood was reflected in the policy stances adopted by Members of Congress. In the post-9/11 period, these legislators became increasingly protectionist. For example, in May 2002, the Congress passed a Farm Bill that raised agricultural subsidies by eighty percent. During the same period, the Congress placed a condition on American fast-track negotiating authority, insisting on a veto over any measures that

\footnotetext{
${ }^{257}$ Ibid., 151.

${ }^{258}$ Ibid.

${ }^{259}$ Ibid., 162.

${ }^{260}$ Ibid., 163.
} 
would dilute U.S. trade remedy laws. ${ }^{261}$ The protectionist mood in Washington was also manifest in the public statements of prominent Bush Administration officials. Even the staunchly pro-free trade U.S. Trade Representative, Robert Zoelick, publicly rejected the notion of a North American customs union at the 2003 NAFTA Free Trade Commission meeting in $2003 .^{262}$ As one Canadian diplomat surmised, it was difficult to see how Canada could have obtained approval for a new trade policy instrument from Congress. ${ }^{263}$ The Bush Administration could not have pursued a customs union-like proposal, or even a more limited agreement that had any semblance to a trade pact.

The prevailing attitude of American legislators reflected broader public antipathy towards the North American Free Trade Agreement. Economic security was a major concern for the majority of Americans. In a 2004 survey conducted by the Chicago Council on Foreign Relations, "Protecting the jobs of American workers," was cited as the most important foreign policy goal for Americans. ${ }^{264}$ Between 2000 and 2003, the U.S. manufacturing sector shed over 2.3 million jobs. Critics such as the American Manufacturing Trade Action coalition placed the blame squarely on NAFTA and similar

\footnotetext{
${ }^{261}$ Even President Bush supported the imposition of new steel tariffs to protect dying manufacturing industries. As the Washington Post commented, "Predictably, that [imposition of the steel tariffs] has spawned a feeding frenzy of protectionism on Capitol Hill -- in which each member wants to show his constituents that he, too, is ready to sell out global trade for the sake of politically powerful interests back home."[David Ignatius, "How Bush Stumbled On Steel" The Washington Post, May 17, 2002, sec. A.] ${ }^{262}$ Steve Chase, "Canada, U.S., Mexico reject customs union as next step," The Globe and Mail, October 8 , 2003 , sec. B.

${ }^{263}$ Confidential interview with an official at the Department of Foreign Affairs and International Trade, dated 2007-12-14.

${ }^{264}$ Economic security even ranked ahead of "combating international terrorism" and "preventing the proliferation of weapons of mass destruction" [Centro de Investigación y Docena Económicas, Consejo Mexicano de Asuntos Internacionales, and The Chicago Council on Foreign Relations, Global Views 2004: Comparing Mexican and American Public Opinion and Foreign Policy (2004), http://www.ccfr.org/ globalviews2004/sub/pdf/Global_Views_2004_US_Mexico.pdf].
} 
trade agreements. ${ }^{265}$ Although the lost jobs in the American economy were likely triggered by growing competition from the Asian economies, NAFTA was a far easier symbol for politicians to attack. This was precisely what textile workers in North Carolina did when their production plants closed. ${ }^{266}$

In the years since the passage of NAFTA, little effort had been made to highlight its accomplishments. Instead, a 1997 Congressionally mandated assessment conducted by the U.S. International Trade Commission found that, while particular sectors either gained or lost from NAFTA, there was no overall discernable effect on GDP, investment, or aggregate employment levels and wages. Moreover, the net effect on American productivity was marginal. ${ }^{267}$ With NAFTA considered a dirty word in the American political lexicon, there was little political currency to be obtained from pursuing any initiative connected to NAFTA. ${ }^{268}$

If the political mood made politicians reluctant to embrace a customs union or a re-opening of NAFTA, they were even more reluctant to embrace a common security perimeter. In the post $9 / 11$ era, American rhetoric reached a fever pitch with respect to the integrity of the country's borders. The new politics of homeland security equated securing America's borders with hardening its border defences. ${ }^{269}$ Homeland security had become a polarizing issue for the American electorate. George W. Bush seized upon

\footnotetext{
${ }^{265}$ United States, Senate Foreign Relations Committee, "NAFTA A Ten Year Perspective and Implications for the Future: Hearing before the Subcommittee on International Economic Policy, Export, and Trade Promotion, $108^{\text {th }}$ Cong., $2^{\text {nd }}$ Sess., 20 April 2004, 62.

${ }^{266}$ Ibid., 4.

${ }^{267}$ J.F. Hornbeck, "NAFTA" in NAFTA Revisited, ed. C.V. Anderson (New York: Nova Science Publishers Inc., 2003), 2.

${ }^{268}$ For example, a NAFTA Panel had ruled in 2001 that the U.S. was violating NAFTA rules with its moratorium on allowing long-haul Mexican trucks into the United States. However, officials in Washington have since been blocked by Congress and from a powerful coalition of labor, environmental and trucking interests [Condon and Sinha, Drawing Lines in Sand and Snow, 50; 59].

${ }^{269}$ See Chapter 1, pages 36-42 for an analysis of the effects of the thickening American border.
} 
the reticence of Democratic Senators to approve the creation of the Department of Homeland Security as a major campaign issue in the 2002 midterm elections; Bush's tactic demonstrated that the politics of security paid dividends. ${ }^{270}$ The fact that a traditionally small-government Republican Administration oversaw the largest expansion in the federal government since the Second World War underscores the extent to which the politics of security had come to dominate the American political landscape.

In Canada, the national mood precluded any initiative designed to deepen cooperation with the United States. While attitudes changed periodically about Canada's relationship with the United States, there had always been a strong undercurrent of scepticism towards close relations with the United States. ${ }^{271}$ Initially, Canadians expressed a great deal of sympathy for their southern neighbours in the months immediately following $9 / 11$. This was reflected in an early pledge to contribute to American military operations in Afghanistan and a re-alignment of Canada's domestic security regime with that of the United States. ${ }^{272}$ Yet as the memory of $9 / 11$ began to fade, there was a measurable swing in the national mood.

The Cabinets of both Jean Chrétien and Paul Martin included seasoned politicians adept at taking the pulse of the nation. Hence, antipathy toward the United States had a

\footnotetext{
${ }^{270}$ President Bush made homeland security the centerpiece of his stump speeches for Republican candidates in the 2002 midterm elections: "We're under threats from an enemy which hates us, and yet they're [Democratic Senate] trying to prevent me and future presidents from being able to do the job." [Robert Draper, Dead Certain: The Presidency of George W. Bush (New York: Free Press, 2007), 172].

${ }^{271}$ See Norman Hillmer, “Are Canadians anti-American?" in Policy Options (July-August 2006), 65.

${ }^{272}$ The Chrétien Government moved to align the Canadian security structure with that of the United States. A new emphasis was placed on intelligence sharing, law enforcement and customs cooperation, as manifest in the Smart Border Declaration. A suite of new legislation was introduced under the Anti-Terrorism Act (ATA). The ATA enacted a broad definition of terrorism, eased electronic surveillance laws, imposed tougher sentences for terrorism offences, criminalized any activity in support of terrorism, and allowed for preventative arrests and detentions. In 2002, the Immigration and Refugee Protection Act was amended to impose higher penalties for immigration offences and declared people deemed security threats ineligible for refugee status [Clarkson, "The View from the Attic: Toward a Gated Continental Community?" in The Rebordering of North America, 76-80].
} 
large impact on the range of policy options discussed around the Cabinet table; the subject of North American cooperation was no exception. One former Cabinet Minister who served under both Martin and Chrétien was especially frank: "The mood around the Cabinet table had substantially shifted since the Cabinet first considered the Smart Borders Declaration in 2001."273 The Cabinet knew that there was no appetite in Canada for re-opening NAFTA. The political sensitivities around the Cabinet table necessitated that the SPP be defined as a much more limited initiative geared towards open borders, maximizing the benefits of NAFTA, and the resolution of certain trade irritants. ${ }^{274}$ The effects of a decidedly anti-American national mood limited the range of politically feasible policy options. An incremental approach tied to repairing the damage caused to Canada-U.S. relations over the Iraq War, was clearly the most that could be accomplished.

In Mexico, a distinct anti-American sentiment informed public opinion in the years after $9 / 11$. The Mexican brand of anti-Americanism had always been different from the Canadian brand, as it was conditioned by the long memory of American interference in Mexican internal affairs. Traditionally, Mexico had maintained a foreign policy based on self-determination and non-intervention. ${ }^{275}$ After $9 / 11$, the prospect of closer security cooperation with the United States prompted bickering between the Fox Administration and the opposition Congress over allegations that Mexico was bending to America's

\footnotetext{
${ }^{273}$ At that time, the sense of Cabinet ministers was that Canadians were stunned by the events of $9 / 11$ and the near shut-down of the border. Accordingly, the Cabinet perceived that there was huge political support for moving ahead with Smart Borders and the Anti-Terrorism Act [Confidential interview with a former Parliamentarian, dated 2007-09-04].

${ }^{274}$ Confidential interview with a former Parliamentarian, dated 2007-09-04.

${ }^{275}$ The Mexican Constitution forbids the foreign deployment of the Mexican Armed Forces. Mexican culture continues to be infused by the lore of rejecting of foreign invaders, as manifest in the number of fiestas throughout the year that commemorate even minor military battles [Confidential interview with a former Canadian Forces officer, dated 2007-07-26].
} 
wishes. ${ }^{276}$ A survey conducted just after $9 / 11$ by Mitovsky Consultants found that, while seventy-six percent of Mexican condemned the terrorist attacks, seventy-three percent still opposed the notion of sending Mexican troops to fight alongside the United States. ${ }^{277}$ When the Fox Administration appeared indifferent to the American decision to create a continental military command, NORTHCOM, the Mexican Congress voted to deny Fox permission to travel to the United States. ${ }^{278}$ The most pro-American Foreign Minister in Mexico's history, Jorge Casteñeda, became a prisoner of this public sensitivity and was forced into making a point blank assertion that, if the United States asked for Mexican military assistance, it would not be provided. ${ }^{279}$

Initiatives that underscored "shared responsibility" were a sine qua non for facilitating Mexico's bilateral cooperation with the United States. As one Mexican diplomat explained, it was always difficult for Mexico to advance its interests with the United States because political actors seized the opportunity to heap blame on the Mexican government. ${ }^{280}$ There was no real public opinion on national security, it was true, beyond pockets of academia and government, but this created an especially influential position for the national media. ${ }^{281}$ Any sort of bilateral security cooperation was portrayed by the media as Mexico ceding sovereignty to the United States. ${ }^{282}$

\footnotetext{
${ }^{276}$ Jeffrey Davidow, The U.S. and Mexico: The Bear and the Porcupine (Princeton: Markus Wiener, 2004), 9.

${ }^{277}$ Condon and Sinha, Drawing Lines in the Sand and Snow (Armonk, NY: ME Sharp, 2003), 24.

${ }^{278}$ Congress demanded that the Fox Administration supply it with detailed information on the implications of the creation of NORTHCOM for Mexico, even though no formal ties with the Mexican Armed Forces had been created under NORTHCOM [Serrano, "Bordering on the Impossible: U.S.-Mexican Security Relations after 9/11," in The Rebordering of North America, 62].

${ }^{279}$ Davidow, The U.S. and Mexico: The Bear and the Porcupine, 4-7.

${ }^{280}$ Confidential interview with an official at the Secretaría de Relaciones Exteriores, dated 2007-09-18.

${ }^{281}$ As a former Mexican national security official observed, "The average Mexican has a sense of insecurity because of the lack of security in the streets. People in Mexico do not think about international security; they are concerned with their own security." [Confidential interview with a professor at the Universidad Autonoma de Mexico (UNAM), dated 2007-09-28].

${ }^{282}$ Ibid.
} 
The only way to ease the constraint imposed by the national mood was to pursue initiatives that manifested U.S. acceptance of the "shared responsibility" principle. With respect to the SPP, Mexican diplomats emphasized the need for American officials to accept joint ownership for border security problems. ${ }^{283}$ The Canadian presence at the trilateral table was also beneficial since it was a clear representation that security interests were not the exclusive domain of Washington. It was also important for creating maneuverability for Mexico within the confines of what was permissible given the national mood. ${ }^{284}$ The SPP working groups were an important tool for managing a difficult relationship with the United States; Mexicans saw it as a tool for bridging historic impediments to cooperation with the United States. ${ }^{285}$

\subsection{The Electoral Cycle}

The SPP was helped along the government agenda by a series of elections in all three countries. The outcomes of these elections were very important for setting government-wide priorities. The 2 July 2000 election of Vicente Fox was a seismic event in Mexican politics. Not only did his election end seventy one years of one-party rule, but Fox came to office convinced that deeper North American integration was the

\footnotetext{
${ }^{283}$ For example, one Mexican security official explained that while Mexico was taking steps to stop the flow of guns across the border, Mexico felt that the flow of guns was an issue of shared responsibility and that Americans should do more on their side of the border to stop the flow of arms south into Mexico [Confidential interview with an official at Secretaría de Gobernacion, dated 2007-09-26].

${ }^{284}$ Framing issues under a trilateral approach helped overcome the constraint in other policy sectors as well, such as reforms to Mexico's energy sector or dialogue between foreign ministers about shared concerns in the Western Hemisphere. For example, U.S. Assistant Secretary of State Roger Noriega told Congress, "But it has of course been a neuralgic issue, and a question of sovereignty of the husbanding of that national resource. It is going to require a dialogue in Mexico, and we can support this effort by being transparent in our interests by showing that we are interested in mutually-beneficial arrangements and putting it perhaps in a North American context." [United States, Senate Committee on Foreign Relations, United States and Mexico: Immigration Policy and the Bilateral Relationship, $108^{\text {th }}$ Cong., $2^{\text {nd }}$ Sess., 23 March 2004, 69]. ${ }^{285}$ Confidential interview with an official at the Department of Foreign Affairs and International Trade, dated 2007-10-02.
} 
solution to Mexico's lackluster economic performance. ${ }^{286}$ From the time that he was a state governor in Guanajuato until the end of his presidency, Fox had a consistent vision for North America, according to an official who served in his office. ${ }^{287}$ When he became President, he had an ever clearer idea of what he wanted to achieve for North America: the addition of a cooperation chapter for NAFTA. ${ }^{288}$

The energy that President Fox initially committed to deepening NAFTA was unmistakable. For example, in 2000 Fox told the Montreal Gazette, "If Canada or Canadians don't like it, it is just as simple as saying no. We can discuss things. Ideas move the world and I want to bring new ideas to this agreement." ${ }^{289}$ In their public statements, President Fox and his first Foreign Secretary, Jorge Casteñeda, also advocated a continental approach to border security and linked migration to NAFTA, precisely because it would be a way to extend the NAFTA partnership beyond merely trade issues. $^{290}$ When Fox failed to secure take-up in Canada or the United States for "NAFTA Plus," he directed his officials to pursue separate bilateral initiatives designed to close the economic gap between Mexico and its North American partners.

\footnotetext{
${ }^{286}$ See Chapter 1, pages 28-30 for an analysis of Mexican economic conditions.

${ }^{287}$ Confidential interview with an official at Secretaría de Economía, dated 2007-09-28. When he was Governor of Guanajuato, Fox established trade centres in major U.S. cities. These trade centres established warehouses for leather goods, distribution networks for agricultural products, and marketing centers for various Guanajuato goods. Governor Fox also spent considerable time promoting his state to North American investors. For example, Fox convinced General Motors to expand its operations in Guanajuato, which brought 3400 new high paying jobs to his state. As he explained, "So I went everywhere in search of ideas on how to bring the fruits of NAFTA past the big corporations, down to the little guy: I wanted free trade that a mother could use to buy milk for her baby, foreign investment in bite-sized pieces we could feed to every hungry fourteen year old facing the trauma of leaving all that he loved to go work "on the other side." [Vicente Fox, Revolution of Hope: the Life, Faith, and Dreams of a Mexican President (New York: Penguin Group, 2007), 150-153].

${ }^{288}$ See Chapter 3, pages 72-74.

${ }^{289}$ April Lindgren, "Fox will address trade issues with Chrétien," The Montreal Gazette, August 22, 2000, sec. B.

${ }^{290}$ Hristoulas, "Trading Places: Canada, Mexico, and North American Security," in The Rebordering of North America, 39.
} 
Both the 2002 Partnership for Prosperity and the 2004 Canada-Mexico Partnership were designed to attract new public and private sector investment to the most underdeveloped regions of Mexico. Fox's intention was to use these bilateral agreements as a stepping stone toward a new North American framework. ${ }^{291}$ The SPP was a step in the right direction for Fox's vision of deepening the North American relationship. He received periodic briefs on the North American Initiative and committed his full support to the initiative. ${ }^{292}$

Vicente Fox's conviction that Mexico had to lead and operate with its North American neighbours to develop a North American outlook set the tone for his administration. After Fox became President of the Republic, several agencies in the federal government began to think about what was meant by a "NAFTA Plus" in order to ensure that their work was consistent with the vision of the President. ${ }^{293}$ Senior officials appointed by Fox were also deeply committed to his vision for North America.

Undersecretary of External Affairs for North America, Gerónimo Gutierrez, was a strong advocate for deepening the relationship with North America. ${ }^{294}$ Officials at Presidencia, led by Eduardo Sojo and Alberto Ortega, also worked tirelessly to deepen the North American relationship.

Eduardo Sojo served as Fox's chief economic advisor and head of the Office of Public Policy (OPP) during the first five years of the Fox Administration. President Fox

\footnotetext{
${ }^{291}$ Mexico, H. Congreso de la Union, Senado de la República, Informe Ejecutivo de la Visita, "Visita de Trabajo del C. Presidente de la República Vicente Fox Queseda a Waco, Texas, en los Estados Unidos de América," 23 March 2005, http://www.senado.gob.mx/gace.php?sesion=2005/04/28/1\&documento=6. ${ }^{292}$ Confidential interview with an official at Secretaría de Relaciones Exteriores, dated 2007-09-18. ${ }^{293}$ Ibid.

${ }^{294}$ See Gerónimo Gutierrez, “America del Norte Retos y Proximo Pasos,” Instituto Mexicano para la Competitividad, (2005), http://www.imco.org.mx/ar43.php; IRPP, "Remarks by the Under Secretary for North America, Gerónimo Gutierrez, at the Conference: North American Integration: Migration, Trade and Security," (Ottawa: IRPP, 2 April 2004), http://www.irpp.org/events/.
} 
designated Alberto Ortega as the senior official with delegated responsibility for the North American relationship; he served as the director of the International Affairs and Competitiveness Unit of the OPP until he replaced Sojo in 2006. ${ }^{295}$ This placed Ortega at the nexus of all North American initiatives pursued by Presidencia: the Partnership for Prosperity, the Canada-Mexico Partnership, and the North American Initiative. The decentralized structure of Presidencia, resulting from the absence of a chief of staff, allowed both men to enjoy unfettered access to President Fox. ${ }^{296}$ Both Eduardo Sojo and Alberto Ortega had a sound understanding of Vicente Fox's vision for North America, and they sat atop the interagency apparatus that would translate Fox's vision into reality across the Executive Branch. The commitment of these three political appointees, and Fox's own energetic pursuit of a North American initiative, was critical for ensuring that the Security and Prosperity Partnership would rise to the very top of the government agenda in Mexico.

The electoral cycle in the United States was important for creating conditions amenable to the pursuit of a trilateral architecture-centric initiative. In 2000, the election of George W. Bush brought a Republican Administration to Washington that was committed to free trade and receptive to pursuing a trilateral initiative designed to improve North American competitiveness. As a border governor from Texas, President

\footnotetext{
${ }^{295}$ Eduardo Sojo was responsible for coordinating economic and international priorities. Sojo served Vicente Fox in a similar capacity in Guanajuato as the then-governor's coordinator for economic planning. Sojo was the rough equivalent of a chief of staff to Fox [Mexico, H. Congreso de la Unión, Cámara de Diputados, Publicaciones, "Gabinete Presidencial: Eduardo Sojo Aldape," http://www.cddhcu.gob.mx/ bibliot/publica/gabinete/eduardos.htm]. Like his boss, Dr. Ortega was also a close collaborator of Vicente Fox, having served as the representative of Guanajuato in Mexico City while Fox was governor of that state. Ortega was the Mexican member of the troika of central agency officials who coordinated the NAI, along with Canada's Phil Ventura and Faryar Shirzad in the United States.

${ }^{296}$ The Office of the President (Presidencia) under Vicente Fox was highly decentralized. There was no chief of staff, but rather three 'super advisors' responsible for coordinating the work of Executive Branch departments. Eduardo Sojo was one of the three super advisors, responsible for the economic cabinet.
} 
Bush was also interested in making Mexico a priority for his Administration. Assistant Secretary of State Noriega underscored the importance of the U.S.-Mexico relationship, testifying before the Senate Foreign Relations Committee in 2004 that, "The United States has no more important relationship than the one it enjoys with Mexico."297 The importance attached to Mexico was also signalled by the President's decision to break with custom and make his first foreign trip to Mexico instead of Canada.

The issue of bringing economic growth to the underdeveloped regions of Mexico was a priority item on the agenda of the Bush Administration. It was identified by the President and senior Administration officials as a way to reverse the flow of migrants across the U.S.-Mexico border. ${ }^{298}$ The American objective for the Partnership for Prosperity was to use public and private sector investments to help create jobs in areas of Mexico that did not benefit from NAFTA. ${ }^{299}$ As one diplomat at the U.S. Embassy in Ottawa explained,

President Bush had a strong vision for the prosperity of North America. If we could increase Mexico's prosperity, then it would filter down to other parts of Central and South America. If this occurred, and the whole region experienced economic growth, then it would also benefit the United States, since it would stem the flow of migration and address some of America's social-immigration problems. ${ }^{300}$

The early commitment of President Bush and Administration officials to mobilizing private sector capital to support Mexican development needs signalled their receptivity to trilateral North American initiatives designed with the limited scope of improving the prosperity of the entire region.

\footnotetext{
${ }^{297}$ United States, Senate Committee on Foreign Relations, United States and Mexico: Immigration Policy and the Bilateral Relationship $108^{\text {th }}$ Cong., $2^{\text {nd }}$ Sess., 23 March 2004, 47.

${ }^{298}$ Ibid., 49.

${ }^{299}$ United States, Senate Foreign Relations Committee: "NAFTA A Ten Year Perspective and Implications for the Future: Hearing before the Subcommittee on International Economic Policy, Export, and Trade Promotion, $108^{\text {th }}$ Cong., $2^{\text {nd }}$ Sess., 20 April 2004, 57.

${ }^{300}$ Confidential interview with an official at the United States Embassy, Ottawa, dated 2007-09-14.
} 
The high priority accorded to Mexico policy on the structured government agenda in Washington was a consequence of the increased importance of the Hispanic vote in American general elections. The 2000 Census in the United States found that twelve percent of Americans were Hispanic; sixty-five percent of these individuals were of Mexican origin. ${ }^{301}$ Since the Hispanic vote had yet to be monopolized by the Democratic or Republican Parties, Washington politicians were open to agenda items that could translate into votes for future elections. Issues relating to the Hispanic community dominated national political discourse after the invasion of Iraq. The highly charged debate around immigration reform had become a top priority on both the Congressional and Presidential agendas. ${ }^{302}$ The cross-cutting political and economic ramifications of the immigration debate affected almost every state. ${ }^{303}$ This made the subject of U.S.-Mexico relations a popular item on the Congressional agenda. ${ }^{304}$ Both Congress and the Bush Administration tended to link the debate on illegal immigration with the need to attract new investment flows to underdeveloped regions of Mexico. ${ }^{305}$ In 2004, Bush

${ }^{301}$ Condon and Sinha, Drawing Lines in Sand and Snow, 18. A separate study commissioned by the Government of Mexico in 2001 estimated that there were about twenty-one million people of Mexican origin living in the United States [Pastor, Toward a North American Community, 82].

${ }^{302}$ With over 40 million Mexicans living in poverty, there is a constant migration flow into the United States. In turn, this migrant flow supplied labour in critical areas of the economy where shortages exist, especially at a time when the economy faced the prospect of the imminent retirement of baby boomers. Illegal immigration also came to be associated with a rise in drug-related crimes and even with concerns about health and environmental effects [United States, Senate Committee on Foreign Relations, United States and Mexico: Immigration Policy and the Bilateral Relationship $108^{\text {th }}$ Cong., $2^{\text {nd }}$ Sess., 23 March 2004, 109].

${ }^{303}$ For example, Senator John McCain of Arizona noted that in his state, since January 2004, 2000 suspected smugglers had been arrested and over 155,000 undocumented migrants have been arrested and violent crime rates were up $400 \%$ [Ibid, 3 ].

${ }^{304}$ For example, when the Senate held hearings on the subject of Mexico in March 2004, turnout was high, with over ten percent of the Senate attending the hearings.

${ }^{305}$ For example, this was the intention of the Bush Administration when pursuing the Partnership for Prosperity. As an example of Congressional interest, Senator John Cornyn of Texas remarked that without economic recovery in Mexico, there would be no end to illegal immigration across the southern border. Senator Christopher Dodd echoed that the announcement of the Partnership for Prosperity was the first step towards addressing the root causes of illegal migration into the U.S. [United States, Senate Committee on 
unsuccessfully attempted to make immigration reform a hallmark of his presidency. ${ }^{306}$

The combination of the immigration debate and the powerful Hispanic vote provided an accelerant to move the SPP initiative-which had a substantive prosperity agenda for Mexico-high up the American government agenda.

Since the SPP was confined to the Executive Branch of government, its upward movement on the presidential agenda benefited from the support of Cabinet and subCabinet appointees who came to office under the patronage of President Bush. One of the most important political appointees in the Bush Administration was Homeland Security Secretary Tom Ridge. As the White House Director of Homeland Security after 9/11, he championed a system of managing the bilateral relationships with Mexico and Canada from the centre of government. Canadian officials working at the Privy Council Office on the Smart Border Declaration were particularly impressed by Ridge. ${ }^{307}$ A second influential appointee was Carlos Gutierrez. He was sworn in as President Bush's Commerce Secretary in January 2005, at the same time as Ridge left the Bush Cabinet. In Ridge's absence, Secretary Gutierrez emerged as the champion of the SPP agenda, though

Foreign Relations, United States and Mexico: Immigration Policy and the Bilateral Relationship $108^{\text {th }}$ Cong., $2^{\text {nd }}$ Sess., 23 March 2004, 40; 45].

${ }^{306}$ The Republican Party had balked at any 'regularization' program for illegal migrants, while the labour movement, closely identified with the Democratic Party, had become more receptive to migrant workers [Ibid, 109].

${ }^{307}$ A former border governor from Pennsylvania, it was felt that Ridge had a good grasp of issues affecting the Canada-U.S. border. He and his staff were very effective in elevating Canadian issues to the top of the White House agenda [Confidential interview with a former official at the Privy Council Office, dated 200709-06]. Several PCO officials spoke of how unusual it was to have a high level advocate for Canada ensconced in the White House; Ridge and Canadian Deputy Prime Minister John Manley also developed an extremely good working relationship and personal friendship. Although Ridge's ability to raise the profile of Canadian issues at the centre of government was diminished when he became Homeland Security Secretary, he remained the most well versed Cabinet officer on the Canada-U.S. file. When Anne McLellan succeeded Manley as Deputy Prime Minister, she was able to maintain an open and accessible relationship with Tom Ridge and his senior officials [Confidential interview with a former Parliamentarian, dated 200709-04]. Ridge also had first-hand experience working with Mexico on the Alianza para la Frontera. In fact, through the Alianza, officials at DHS and CISEN established very good working relationships. 
with a particular commitment to the issue of North American competitiveness. ${ }^{308}$

Officials from his Commerce Department were excellent interlocutors for Canadian

officials at the PCO. ${ }^{309}$ These two Cabinet secretaries were important for maintaining

high-level support for a process-driven initiative that balanced security and prosperity on

the Bush Administration's agenda.

President Bush's political appointees on the National Security Council (NSC)

were responsible for working with Cabinet and sub-Cabinet level officials to steer the

SPP through the NSC process. The involvement of the senior NSC staff was critical for

ensuring action on the North American Initiative that was brought under the NSC

interagency process in 2003 , since the process of securing political take-up had to be

managed through the NSC's principals' and deputies' committees. ${ }^{310}$ Through these

\footnotetext{
${ }^{308}$ Carlos Gutierrez had a personal interest in the subject, having worked as a corporate executive in all three North American countries for Kellogg Company. He understood the threat to North American competitiveness posed by India and China's economic performance and he became a powerful promoter in Washington of using the SPP as a vehicle for improving North American competitiveness. Gutierrez had first hand knowledge of the challenges of operating lines of production on a North American basis, having worked as a sales representative for Kellogg's in Mexico City and as a Kellogg's executive in Canada, before returning to the United States to become the company's Chairman and CEO in 1999. He also had first-hand experience with the competitive pressures faced by American multinationals, having to close Kellogg's ninety three year old plant in Battle Creek Michigan in 1999 [Paloma Dallas, "Thinking outside the Box: With Courage and Competence, Carlos Gutierrez Guides Kellogg's," Hispanic Magazine.com (March 2002), http://www.hispaniconline.com/magazine/2002/march/ features/kelloggs.html]. Officials with the Council of the Americas and the U.S. Chamber of Commerce emphasized the personal commitment of Secretary Gutierrez driving the SPP in Washington. PCO officials also acknowledged that the Department of Commerce was a very active promoter of the NAI in the inter-agency process prior to Waco.

${ }^{309}$ Confidential interview with a former official at the Privy Council Office, dated 2007-09-19.

${ }^{310}$ The NSC Policy Coordination Committees (PCCs) are composed of substantive experts and senior officials from the relevant Executive Branch departments and agencies. The PCCs are the forum for policy development. PCC planning is more focused on strategic and political level planning, whereas departmental or agency planning in the Executive Branch is focused more on operational policies. The final outcome of the PCC process is an integrated policy document, similar to the Memorandum to Cabinet in the Canadian system, that identifies key judgments, considerations, and recommendations for review and approval by the two higher tiers of the NSC Council system: the Deputies Committee (DC) and the Principals' Committee (PC) [Elizabeth McKune, Frederick C. Smith, and Alan G. Whittaker, The National Security Policy Process: the National Security Council and the Interagency System (Research Report, April 2007 Annual Update), Washington, D.C.: Industrial College of the Armed Forces, National Defense University, U.S. Department of Defense, http://www.ndu.edu/icaf/NSC_Report_2007_FINAL20_April.pdf]. The NAI had to pass through this interagency system. The majority of the work on the NAI
} 
committees, the NSC served as the link between the President's Cabinet and senior government officials. Two of the individuals who were responsible for shepherding the NAI through its development stage and the interagency process, Gary Edson and Faryar Shirzad, were both close to President Bush and his political staff, having served on the Bush-Cheney Transition team. ${ }^{311}$ Ambassador Thomas Shannon and Daniel Fisk were two appointees on the NSC Western Hemisphere staff who also lent their support to the NAI. ${ }^{312}$ High level support from these NSC appointees was critical for the ascent of the NAI on the White House agenda. Bringing the NAI under the NSC interagency process guaranteed that the SPP would be elevated to become a government-wide priority across all relevant departments and agencies. ${ }^{313}$

One difference that distinguished Canada from its North American partners was that, regardless of the outcome of a Canadian election, the senior ranks of the public service remained almost unchanged. This condition ensured that policy work on the NAI could continue uninterrupted despite the changes in government. Nevertheless, the electoral cycle was important for obtaining political buy-in to the SPP. In the last years of Jean Chrétien's premiership, there was very little scope for pursuing the North American Initiative. In 2000 and 2001, Prime Minister Chrétien poured cold water on

was done at the PCC level; one official involved in the process could not recall any substantive issue that had to be resolved at the DC or PC level [Confidential interview with a United States Government Official, dated 2007-12-13].

311 Gary Edson was the Deputy Policy Director for the Transition Team, while Shirzad was the International Trade policy coordinator. Both Edson and Shirzad were members of the American team of policy entrepreneurs. For an analysis of their entrepreneurial activity, see pages 135-137.

${ }^{312}$ Canadian officials indicated that Tom Shannon had the ear of Condoleezza Rice [Confidential interview with a former official at the Privy Council Office, dated 2007-09-19]. He moved with Rice to the State Department in early 2005 to become Assistant Secretary of State for the Western Hemisphere. After Shannon's departure, Daniel Fisk assumed the role of senior coordinator for the SPP at the National Security Council.

${ }^{313}$ In this section, the NAI and the SPP are used interchangeably. As noted in footnote 20 , the NAI refers to the policy model that underpins the SPP. The SPP was the name given to this policy model just before its announcement at Waco. The NAI is referenced in this chapter, because until Spring 2005, this was the name assigned to the initiative championed by these political appointees. 
Vicente Fox's proposals for pursuing a "NAFTA Plus." 314 While officials at the Privy

Council Office did have the blessing of the Prime Minister to proceed with informal discussions on the NAI, the problem was that Chrétien's advisors in the Prime Minister's Office (PMO) never seemed interested in pursuing the initiative with President Bush. ${ }^{315}$ The first opportunity for the Prime Minister to raise the NAI came during the 2002 bilateral meeting with President Bush in Detroit, but it seems as though the proposal was never raised. ${ }^{316}$ With the efforts of Chrétien to publicly distance his government from the Bush Administration, and his announcement of a retirement date for December 2003, there was little incentive for Canadian officials to attempt to generate political-level support for the NAI.

In December 2003, there was a transition of power within the Liberal Party, when Paul Martin succeeded Chrétien as Prime Minister. This provided a new window for Canadian officials to obtain political buy-in for the NAI, since Martin came to office promising to restore better relations with the United States. The Prime Minister and President held three bilateral meetings in $2004 .{ }^{317}$ The priority that Martin attached to improving the bilateral relationship was signalled early in his premiership by the

\footnotetext{
${ }^{314}$ Canadian officials did not want to commit resources to Mexico when it was believed that Mexico had failed to take advantage of the NAFTA windfall to invest in its own people [Duncan Woods, "Sharing the Wealth? Economic Development, Competing Visions, and the Future of North America," in Canadian and Mexican Security, 20].

${ }^{315}$ Confidential interview with a former official at the Privy Council Office, dated 2007-09-19.

${ }^{316}$ Despite Chrétien's lukewarm attitude toward the North American Initiative, Deputy Prime Minister John Manley was a very strong proponent of the NAI [Confidential interview with a former official at the Privy Council Office, dated 2007-09-05]. In the aftermath of 9/11, the Prime Minister had appointed Manley to chair the Cabinet Committee on Public Safety and Anti-Terrorism. He retained his chairmanship of this committee until the end of the Chrétien Administration. As committee chairman, he ensured that the issue of identifying the next level of engagement with the United States remained on the Cabinet agenda. Under Manley's oversight, the Borders Task Force at the Privy Council Office drafted the North American Initiative white paper and began the early consultations with Mexico City and Washington on that initiative. After leaving public office, John Manley's commitment to furthering North American integration was manifest in his role as the Canadian co-chair of the Council on Foreign Relations Task Force on the Future of North America.

${ }^{317}$ The first bilateral meeting was held in Monterrey in January 2004. The second occurred at the White House in April 2004. The third meeting took place in Ottawa in November 2004.
} 
announcement that he would chair a new Cabinet Committee on Canada-U.S. relations;

the committee was supported by the Canada-U.S. Secretariat at the Privy Council Office.

By centralizing management of the Canada-U.S. relationship under his control, Martin

signaled that he was ready to pursue a new positive engagement with the United States.

Prime Minister Martin's approach to Canada-U.S. relations was communicated in

a 2004 speech that he delivered in Washington. The speech suggested that, in contrast to

his predecessor, Martin was ready to accept a new process-driven North American

framework:

Frankly, we are continually astonished at how quickly the border can be closed when pressures erupt in the United States. Fifteen years after the Canada-US free trade agreement, ten years after we trilateralised it with Mexico under NAFTA, we should be able to do better. We have to recognise that ours is a North American economy...Protectionism benefits no one. We will consider other areas as well where a North American perspective benefits both countries, for example energy, the electricity grid and the environment, where we are looking at ways to intensify bilateral co-operation to maintain clean air and water for both countries. ${ }^{318}$

The underlying message of the speech was that the Canadian Government was willing to make a concerted effort to demonstrate a positive relationship with the Bush White House.

Early on in his administration, Martin gave his blessing for the PCO to continue trilateral meetings with the National Security Council and Presidencia. The Martin PMO was interested in getting along well with the United States on the one hand, while preserving Canadian sovereignty on the other hand. ${ }^{319}$ The SPP's emphasis on process

\footnotetext{
${ }^{318}$ Canada, Library and Archives Canada, Prime Minister of Canada Paul Martin, "Address by Prime Minister Martin on the Occasion of his visit to Washington," 29 April 2004, http://epe.lacbac.gc.ca/100/205/301/prime_minister-ef/paul_martin/06-02-03/www.pm.gc.ca/eng/news.asp@id=192.

${ }^{319}$ Confidential interview with a former official at the Privy Council Office, dated 2007-08-14. An example of this variegated attitude was the decision that the Martin Government took on Ballistic Missile Defence. In April 2003, Martin had campaigned for the Liberal leadership indicating he thought Canada should support the construction of an American continental Ballistic Missile Defence (BMD) system. In February 2005, he rejected the BMD system arguing that Canada was a sovereign country and "you don't
} 
over content suited the political preferences of the Martin PMO, insofar as the Prime Minister could use the framework to demonstrate an improvement in the bilateral relationship with the United States, while on the other hand protecting his minority government from nationalist backlash.

The ascent of the SPP on the Canadian government agenda was facilitated by the support of powerful Cabinet Ministers, especially Anne McLellan and David Emerson. ${ }^{320}$ The support of these Ministers was important, given that there was scepticism in Cabinet about the utility of pursuing a North American framework agreement that would do little to resolve the bilateral issues of the day, such as the closure of the American market to Canadian cattle, the Devils Lake water conflict, the renewal of the NORAD agreement, or the festering softwood lumber trade dispute. ${ }^{321}$ Officials in the Canada-U.S. Secretariat also worked to keep the SPP on the Cabinet agenda by enlisting Cabinet Ministers to provide quarterly updates on the SPP to their colleagues on two of Martin's Cabinet committees. ${ }^{322}$ This Cabinet-level review of the SPP allowed the initiative to move higher up the government agenda in Ottawa. The support of the Prime Minister and senior Cabinet Ministers was essential for providing the Canada-U.S. Secretariat with the

intrude on a sovereign country's airspace without seeking permission" [Clifford Krauss, "Divergent Paths: Canada Breaks with U.S. Over Missile Shield," New York Times, February 27, 2005, sec. A].

${ }^{320}$ In addition to being Deputy Prime Minister and Minister of Public Safety, Anne McLellan was also the chair of two Cabinet committees: the Operations Committee and the committee on Security, Public Health and Emergencies. Like Carlos Gutierrez, David Emerson had a background as a corporate executive; he was the CEO of CanFor Corporation. As a trained economist, the subject of North American competitiveness was a high priority for him.

${ }^{321}$ Confidential interview with a former official at the Privy Council Office, dated 2007-09-19.

${ }^{322}$ Sometimes, the two relevant Cabinet committees - the Canada-U.S. Committee and the Security, Public Health and Emergencies Committee-were brought together so that Ministers could be briefed on the whole picture, rather than receive isolated briefings. Often, the $\mathrm{PCO}$ would ask individual ministers to give the committees updates on the SPP issue relevant to their portfolio [Confidential interview with a former official with the Privy Council Office, dated 2007-09-19]. At the same time, Phil Ventura coordinated the inter-departmental process through a PCO-led committee of Assistant Deputy Ministers. 
political backing required to keep the SPP on the top of the agenda for government

departments and agencies in Ottawa.

\subsection{Turf Battles}

The number of departments and agencies responsible for deliverables on the SPP

Work Plan was staggering. In the United States, over twenty three federal departments

and agencies participated in the SPP working groups. In Canada, there were over

fourteen line departments and agencies involved in the initiative. In Mexico, at least

eleven departments and agencies participated in the SPP. ${ }^{323}$ With a large number of

actors participating in a whole-of-government exercise, turf battles were inevitable. This

raised the specter that bureaucratic warfare could derail the upward trajectory of the SPP

on government agendas.

In Canada, each department had its own vested interests; some departments did

not want to become involved with a framework agreement larger than its own parochial

interests. ${ }^{324}$ The departments that generated the most resistance were those that felt they

\footnotetext{
${ }^{323}$ In Canada, participants include: Health Canada, Public Safety Canada, the Canadian Food Inspection Agency, Transport Canada, the Canadian Nuclear Safety Commission, the Canadian Border Services Agency, Foreign Affairs and International Trade, Natural Resources Canada, Industry Canada, the Department of National Defence; Environment Canada, the Treasury Board Secretariat, Finance Canada, Agriculture Canada, and the Privy Council Office. The U.S. departments and agencies that participate in the SPP include: the Department of Health and Human Services, Department of Defense, Department of Homeland Security; Department of Commerce, Department of Justice, the U.S. Drug Administration, State Department, Department of Energy, Department of Transportation, US Section-International Boundary Water Commission, Animal and Plant Health Inspection Service, U.S. Coast Guard, the Customs and Border Patrol, the Transportation Security Administration, Immigration and Customs Enforcement (ICE), National Counter Terrorism Center, Central Intelligence Agency, Homeland Security Council, Office of Management and Budget, National Security Council, Office of U.S. Trade Representative, Department of the Treasury, and the Environmental Protection Agency. Mexican participants include: Centro de Investigacíon y Seguridad Nacional [CISEN], Secretaría de Economia, Secretaría de Agricultura, Secretaría de Energia, Secretaría de Communicaciones y Transportes, Secretaría de Salud, Secretaría de Medio Ambiente y Recursos Naturales, Procuraría General de la República, National Migration Institute, Secretaría de Hacienda y Crédito Público, Servicio Nacional de Sanidad, Inocuidad y Calidad Agroalimentaria [Judicial Watch, http://www.judicialwatch.org/archive/2007/dhs06978spp14mar07_001.pdf].

${ }^{324}$ Confidential interview with a former official at the Privy Council Office, dated 2007-11-06.
} 
possessed a sound understanding of their bilateral agenda and did not need the extra push from central agencies. For these departments, the SPP was perceived to be a resource siphon and "make work." ${ }^{325}$ On the other hand, there were some departments that saw the SPP as an opportunity to secure new funding, highlight departmental initiatives, or take advantage of central agency involvement to generate progress on a sticky bilateral issue. ${ }^{326}$ In the United States, a similar dichotomy existed. Some departments, such as the Department of Transportation eagerly embraced the SPP. Other departments were less enthusiastic; they were open to pursuing the trilateral initiatives, but preferred their own methods to the SPP framework. ${ }^{327}$ When turf battles did arise, they were manageable since the central agencies of all three countries had program responsibility for managing and coordinating the SPP.

The fact that the central agencies were not only coordinating, but also driving, the development of the SPP framework, limited the scope for line departments to obstruct the rise of the SPP on the governments' agendas. Since central agencies reported directly to the Cabinet and national leaders, they carried a big stick to force reluctant line departments into compliance. Since the SPP originated in the central agencies of each country, the scope was limited for line departments or agencies to challenge the place of the SPP on the government agenda.

With so many agencies involved, the challenge for central agency officials was to keep the coordination process orderly. In Canada, the Privy Council Office's Phil Ventura led an inter-departmental committee of Assistant Deputy Ministers who were

\footnotetext{
${ }^{325}$ Confidential interview with a former official at the Privy Council Office, dated 2007-10-02.

${ }^{326}$ Departments that had participated in Smart Borders were content to continue cooperating under the management-from-the-centre framework of the SPP [Confidential interview with a former official at the Privy Council Office, dated 2007-10-02].

${ }^{327}$ Confidential interview with an official of the United States Government, dated 2007-12-14.
} 
tasked with populating the SPP agenda. ${ }^{328}$ The existence of this committee was a powerful tool for consensus-building and managing interdepartmental rivalries. In the United States, the National Security Council (NSC) managed the inter-agency process. The core theme set by the NSC was that the U.S. did not want to undermine the openness that lay at the heart of its prosperity. ${ }^{329}$ As one American official remarked, "There was nothing like having an issue on the President's agenda." 330 The interagency process ensured that it would no longer be the exclusive prerogative of the Department of Homeland Security to manage the border relationship; through the SPP framework, discussion of the impact of border security measures on the continental economy would include departments and agencies that did not have a formal security mandate. ${ }^{331}$ In fact, one official at the Department of Transportation noted that he attended meetings where Customs and Border Patrol was represented much more frequently in the aftermath of SPP, than prior to the SPP when the security agencies simply were not coordinating with other departments in Washington. ${ }^{332}$ In a city renowned for its turf battles, NSC involvement was critical for bringing security and prosperity agencies together to discuss a North American agenda for the first time. Central agency management in Canada and the United States prevented turf battles from restricting the rise of the SPP on each government's agenda. $^{333}$

\footnotetext{
${ }^{328}$ Confidential interview with a former official at the Privy Council Office, dated 2007-10-02.

${ }^{329}$ Confidential interview with a United States Government official, dated 2007-12-13.

${ }^{330}$ Ibid.

${ }^{331}$ Confidential interview with a United States Government Official, dated 2007-12-13.

${ }^{332}$ Confidential interview with an official at the Department of Transportation, dated 2007-12-14.

${ }^{333}$ In Mexico, turf battles took a different form, because bilateral security cooperation was new for Mexico. The challenge for CISEN was to gain acceptance of its role as a coordinator in the Mexican security and intelligence community; a role that did not naturally fit its mandate [Confidential interview with an official at Secretaría de Gobenacion, dated 2007-09-27]. Nonetheless, since North American cooperation was a high priority of President Fox with his most trusted advisors, Sojo and Ortega, overseeing the file, interagency coordination was expected.
} 


\subsection{Balance of Organized Political Forces}

Although events in the political stream aligned to permit the rise of the SPP on the governments' agenda, one last element was necessary in order to remove the final obstacle to the SPP's upward movement on the government agenda: obtaining the endorsement of the private sector. In most applications of the multiple streams model, the coalition building activity involves building alliances between the Executive and Legislative branches of government. However, since the SPP was explicitly designed to ride above the Legislative Branch, ${ }^{334}$ there was no need to build coalitions with legislators in the three countries. Since the SPP agenda was very technical and process-oriented, government actors did not perceive the need to consult with civil society groups. This left only one stakeholder group that required some political heavy-lifting. The business community had to be brought on board with accepting an incremental, process-driven North American policy.

The private sector, especially in Canada, had been vocal in identifying the need to pursue customs union-like and security perimeter-like proposals with the United States. ${ }^{335}$ However, organized business interests were also pragmatic: at the end of the day, even a less-than-desirable incremental approach to North American integration was preferable to inaction. As the coalition-building process began in earnest, this was the message conveyed by the private sector. For example, in the years after 9/11, the Can-Am Border Trade Alliance had abstained from endorsing any of the big vision proposals for North America. Its biannual conferences were well attended by government officials, and the

\footnotetext{
${ }^{334}$ While the Canadian Parliament and U.S. Congress did hold hearings on NAFTA around its ten year anniversary, legislators in both countries did not attempt to insert themselves into the SPP policy process. In Mexico, the government had formal reporting requirements to Congress, but the Fox Administration did not involve Congress in an active way.

${ }^{335}$ See Chapter 2, pages 56-61.
} 
message was simple: fix the border. ${ }^{336}$ Other sectors, such as the trucking and rail sectors also had a strong interest in deepening economic integration and resolving outstanding regulatory and standards differences. ${ }^{337}$ One of the most vocal Canadian business groups, the Canadian Trucking Alliance, had been urging the Canadian government for some time to move toward a Smart Borders II to get the focus back on the need to improve border security without impairing trade. ${ }^{338}$ These public-private sector exchanges suggested to government officials that there was significant room for obtaining private sector support for a process-driven initiative that treated security and prosperity as co-dependent.

In 2004 , momentum continued to build for obtaining private sector support. In March of that year, the Canadian Chamber of Commerce and the U.S. Chamber of Commerce co-hosted an event in Washington on the subject of North America. Tom Donahue, the CEO of the U.S. Chamber of Commerce, expressed support for a framework initiative that recognized the need to balance security and prosperity: "Many people talk about 'striking a balance' between commerce and security, as if to imply that the only solution is to accept a little less prosperity and a little less security. But that's not good enough in my book. We should aim higher and find win-win solutions for trade and safety." ${ }^{, 39}$ This jibed nicely with the message being communicated by Canadian Cabinet Ministers. For example, Paul Martin's Parliamentary Secretary for Canada-U.S.

\footnotetext{
${ }^{336}$ The conferences gave government officials the opportunity to discuss border facilitation, trusted traveler and cargo security programs. In turn, business representatives seized the opportunity to lobby the government on specific one-off initiatives, such as the need to create special processing zones that would allow U.S. and Canadian customs officials to work jointly on either side of the border. [Can/Am Border Trade Alliance, "April 2004 Ottawa Conference Summary Highlights, http://www.canambta.org/ ott_2004_summary.pdf].

${ }^{337}$ This would have the effect of lowering non-tariff barriers by improving freight delivery systems and providing low delivery costs for business [Condon and Sinha, Drawing Lines in Sand and Snow, 38].

${ }^{338}$ Canadian Trucking Alliance, "Canadian Trucking Alliance Welcomes Bush-Martin Security/Prosperity Framework," (Ottawa: 30 November 2004), http://www.cantruck.com/news/news/2004/041130.htm. ${ }^{339}$ Thomas Donahue, “Opening Remarks: U.S.-Canada Business Dialogue," United States Chamber of Commerce (Washington: 31 March 2004), http://www.uschamber.com/press/speeches/2004/040331 tjd_ canada.htm.
} 
Relations, Scott Brison, spoke at the same event about the need to advance the Smart Regulations agenda, and to move forward in improving technical areas of NAFTA cooperation such as rules of origin. He concluded by stating the Government's emerging policy stance, "This is not about a Big Deal or a 'Big Bang.' There is a great potential for substantive progress with a significant number of "little deals.",340

Just one month later, the Canadian Council of Chief Executives (CCCE) signalled its support for a more incremental North American policy. Tom d'Aquino wrote in April 2004 that, "Whether Canada chooses to deal with individual issues incrementally or opts for broad negotiations with links between issues we need to develop a strategy that is comprehensive and coherent." ${ }^{341}$ This coincided with a period of intensified dialogue between government officials and the private sector. The CCCE succeeded in attracting senior members of the Bush and Martin Administrations to attend its annual CEO conference in Washington in April 2004. ${ }^{342}$ Later that year, the CCCE co-hosted a Canada-Mexico business retreat with the Consejo Mexicano des Hombres de Negocios. It used the opportunity to sell the Mexican business community on the CCCE's North American Security and Prosperity Initiative. ${ }^{343}$ In both the public and private sectors, momentum was undoubtedly gathering in a direction favourable to the pursuit of a process-driven North American initiative.

\footnotetext{
${ }^{340}$ Canada, Embassy of Canada in the United States, "Joint Meeting of the Canadian Chamber of Commerce and the U.S. Chamber of Commerce," (Washington: 31 March 2004), http://canadianembassy.org/homepage/040331-en.asp.

${ }^{341}$ Thomas d'Aquino, "Towards a New North America," in Viewpoint Americas 2, no. 2 (New York: Council of the Americas, 16 March 2004), http://www.ceocouncil.ca/en/view/?document_id=308\& type_id $=3$.

${ }^{342}$ The meeting was attended by the Canadian Ambassador in Washington, Michael Kergin, White House Chief of Staff Andy Card, Commerce Secretary Don Evans, and Homeland Security Director, John Gordon [Barrie McKenna, "Canada-U.S. Relations Seen Getting Worse; Rising Protectionism in the U.S. and Election Year Angst Over Foreign Outsourcing Cited," The Globe and Mail, April 20, 2004, sec. B] ${ }^{343}$ See Chapter, page 61.
} 
Another signal that the government had succeeded in obtaining support from the private sector was manifest in the reaction to the announcement of the New Partnership in North America (NPNA). ${ }^{344}$ The immediate reaction of the business community was encouraging for senior government officials who had floated the NPNA as a trial balloon for the SPP. For example, the Canadian Trucking Association and the American Trucking Association issued a joint statement welcoming the announcement. ${ }^{345}$ About a month prior to the launch of the SPP, d'Aquino took his message on the road softening up business audiences in five U.S. cities on the need to pursue a framework agreement that treats security and prosperity as inseparable:

On the economic front, we should aim for nothing less than a seamless market for trade in goods. On security, we need to build on the Smart Border agenda to make this seamless market a practical reality... I think it is important to articulate a trilateral vision of North America as well as a strategy that involves coordinated efforts by all three countries. We will not always be able to proceed at the same speed among all three countries, but whether we proceed bilaterally or trilaterally, we cannot afford to wait. ${ }^{346}$

Even the Canadian Chamber of Commerce, an early promoter of the common security perimeter, welcomed the SPP, labelling it as a 'very positive step' in moving forward on trade and competitiveness issues. ${ }^{347}$ The Independent Task Force on the Future of North America also indicated that their report was more of a long-term blueprint, rather than a demand for immediate action on content-driven initiatives. Their willingness to accept

\footnotetext{
344 The NPNA was announced at the conclusion of President Bush's visit to Canada, 30 November-1 December 2004, as part of the Canada-U.S. Joint Statement on Common Security, Common Prosperity, and a New Partnership in North America.

${ }^{345}$ Canadian Trucking Alliance, News Release, "Joint Statement: Enhancing Security and Commercial Traffic Flow at the Peace Bridge," (Buffalo: 8 December 2004), http:///www.cantruck.com/ news/ news/ 2004/041208.htm.

${ }^{346}$ Thomas d'Aquino, "Beyond Free Trade: A Canada-United States Partnership for Security and Prosperity, Notes for remarks in Dallas, Tuscon, Phoenix, Cleveland, and Buffalo," (24 February to 3 March 2005), http://www.ceocouncil.ca/en/view/?document_id=393\&type_id=3.

${ }^{347}$ Canadian Chamber of Commerce, "Trilateral Agreement Welcomed By Business," (Ottawa: 23 March 2005), http://www.barriechamber.com/broadcast/enews/Newsletter/05-03-23CCC.pdf.
} 
the Security and Prosperity Partnership as an initial step was suggested in the comments of the Task Force's Mexican vice-chair, Andrés Rozental, “The [Task Force] blueprint was developed with a sense of what should be done, rather than what can be done. The three governments now have a set of objectives - short and medium term goals - that can be used to plan for the North America of the $21^{\text {st }}$ century." 348 Some members of the Independent Task Force, who had presented an ambitious wish list of content-driven proposals, appeared receptive to starting with the architecture-centric SPP.

Developments in the politics stream contributed to the rise of the SPP on the structured agendas of all three countries. Electoral politics and national mood precluded anything but the emergence of an architecture-centric framework agreement for North America. The absence of controversial big vision initiatives and a strong emphasis on architecture allowed the SPP to overcome most of the constraints that existed in the politics stream. The emphasis on architecture was exactly what was required to prevent the initiative from stalling on the government agenda, precisely because the SPP framework lent itself to central agency management. The receptivity of political appointees and the snowballing support of the business community secured a place for the SPP high on the structured agendas of the three governments.

\footnotetext{
${ }^{348}$ Andrés Rozental, "The Security and Prosperity Partnership: An Overview," in International Journal 61, no. 3 (Summer 2006), 544.
} 


\section{CHAPTER 5: AGENDA CHANGE}

The movement of the SPP from the policy backburner to the decision agenda for the three national leaders at the Waco Summit required events in the three streamsproblem, policy, and politics—-to join together. The streams could only be brought together when a window of opportunity opened. In addition, policy entrepreneurs were required to couple the streams and advocate linkages between problems and solutions, policy options and political considerations, in order to generate agenda change. This chapter will analyze why the policy window opened in the Fall of 2004, and the role of policy entrepreneurs in Canada and the United States who brought the three streams together for national leaders when the window opened.

\subsection{The Opening of the Policy Window}

The multiple streams analysis permits a policy window to open in either the politics stream or the problem stream. Since the four problems that figured prominently on the government agenda were longer term problems, it was difficult to argue that any single problem forced open a policy window. In contrast, a very specific window of opportunity opened in the politics stream. There were three major events that defined this open window: the November 2004 American presidential election, the working visit of Vicente Fox to Canada between 24 and 26 October 2004, and the visit of George W. Bush to Canada between 30 November and 1 December 2004.

The electoral cycle in the three countries had a big impact in determining when the policy window would open. The first trilateral discussions on the North American Initiative occurred in the spring of 2003. At that time, however, all three governments 
were distracted by the.politics at the United Nations surrounding the American-led invasion of Iraq. As one former PCO official explained, if there was a single event that nearly derailed the NAI, it was Iraq. ${ }^{349}$ Mexico was placed in an extremely uncomfortable position since it held a seat on the U.N. Security Council. ${ }^{350}$ Although Canada did not sit on the Security Council at the time, its decision to withhold support for the invasion is widely believed to have generated the Bush Administration's decision to cancel a previously planned state visit to Canada in May 2003.

As soon as tensions over Iraq began to recede, Mexico held its mid-term congressional elections. During the election season, Mexican politicians and officials at Presidencia were preoccupied. They hoped that the elections would produce a victory for President Fox's PAN party, in order to end the gridlock that the President encountered working with an opposition Congress. ${ }^{351}$ The Mexican President had encountered significant trouble enacting his legislative agenda, especially since his Cabinet lacked skilled political operatives capable of forging the requisite alliances in Congress. ${ }^{352}$ However, the election results proved disappointing for Vicente Fox and he was forced to work with an opposition Congress for the remainder of his term.

Once the elections wound down in Mexico, there was little scope to move the NAI from the policy backburner because Canada experienced a change in a government. In

\footnotetext{
${ }^{349}$ Confidential interview with a former official at the Privy Council Office, dated 2007-09-19.

${ }^{350}$ Prime Minister Chrétien and President Fox exchanged phone calls almost daily in the lead up to the war in Iraq. Fox described the conversations in his memoirs as comparing notes on 'what it was like to sleep with the elephant,' in response to pressure from the Bush Administration on Canada and Mexico to support the U.S. at the United Nations [Fox, Revolution of Hope, 283].

${ }^{351}$ Mexico's Congress grew increasingly hostile toward the Fox Administration. For example, it stalled proposals for tax reform and Indian rights. Eduardo Sojo observed that the Fox Administration had experienced a series of setbacks in domestic and foreign policy and had learned that "political agreements have their own rhythm." [Ginger Thompson, "U.S.-Mexico Relations: Alliance Meets Boundaries," New York Times, March 23, 2002, sec. A].

${ }^{352}$ Davidow, The U.S. and Mexico: The Bear and the Porcupine, 164.
} 
December 2003, outgoing Prime Minister Jean Chrétien was succeeded by his party’s newly elected leader, Paul Martin. The change of Administration in Canada boded well for the introduction of the North American Initiative since, as noted above, Martin had pledged to improve Canada's relationship with the United States. ${ }^{353}$ However, two obstacles existed once Martin took office. First, the new Prime Minister was anxious to call a general election in order to obtain a popular mandate to govern. ${ }^{354}$ Until the election was held in June 2004, it was unrealistic for officials in the Privy Council Office to attempt to move the NAI to the decision agenda. The second obstacle to progress on the NAI existed in the United States.

The year 2004 was an election year. The political class in Washington was seized by what was anticipated to be a very close general election campaign for the American presidency. Officials at the Privy Council Office and their counterparts in the National Security Council were reluctant to promote the NAI at a time when it was unclear if President Bush would be re-elected. It was also difficult for Canadian officials to obtain a hearing for the NAI in Washington since the political appointees at the NSC were preoccupied with the election. After all, if President Bush failed to be re-elected, these officials would be out of work. ${ }^{355}$ Before and after the presidential election, turnover of the political appointees at the NSC also created an obstacle to elevating the NAI through

\footnotetext{
353 See Chapter 4, pages 111-114.

${ }^{354}$ To the great surprise of the Liberal Party, Paul Martin failed to win a majority in the election. He was forced to lead a minority government in Parliament.

${ }^{355}$ When senior PCO officials were in Washington, they would often have to stop in at the White House to remind their NSC colleagues about the NAI [Confidential interview with a former official at the Privy Council Office, dated 2007-09-19].
} 
the various stages of the NSC interagency system necessary for it to reach the decision agenda. $^{356}$

The re-election of George W. Bush in November 2004 was the political event that opened the policy window. Free from the demands of a gruelling election campaign, and presented with a positive initiative upon which President Bush could begin his second term in office, political buy-in for the NAI was obtained in the White House. A State Department official explained, "To a certain extent, what we're doing here [with the NAI] is setting a strategic vision, or a positive vision, for the bilateral relationship over the next four years." ${ }^{357}$ The Bush Administration was equally interested in engaging Mexico in a positive initiative. As one Canadian official noted, the White House interest was present from the beginning; the SPP was not a case of Canada and Mexico dealing with a reluctant White House. ${ }^{358}$ By accepting the SPP, Americans abandoned their traditional preference for dual-bilateralism in exchange for a new trilateral framework for North America.

Two working visits to Ottawa completed the opening of the policy window. Vicente Fox's visit augured a new beginning for the Canada-Mexico bilateral relationship. Between 24 and 26 October, President Fox visited Canada to commemorate the sixtieth anniversary of the bilateral relationship. His working visit demonstrated

\footnotetext{
${ }^{356}$ Even after the election, there was a time delay in launching the NAI, because there was a turnover of NSC officials. In June 2004, Faryer Shirzad replaced Gary Edson as Deputy National Security Advisor. Then, in January 2005, Daniel Fisk replaced his boss, Ambassador Thomas Shannon, as Senior Director for the Western Hemisphere. As a result of these changes, Fisk became the principal NSC official responsible for shepherding the SPP through the final stages of the inter-agency process. It took some time for him to become familiar with the NAI brief. This created an additional delay in moving the NAI through the interagency system [Confidential interview with a former official at the Privy Council Office, dated 200709-19].

${ }^{357}$ United States, State Department, US INFO, "Background Briefing by a Senior Administration Official on the President's meetings with Prime Minister Martin," (Ottawa: 30 November 2004), http://www.america.gov/st/washfile-english/2004/December/20041201114924ASrelliM0.1756555.html. ${ }^{358}$ Confidential interview with an official at the Department of Foreign Affairs and International Trade, dated 2007-10-02.
} 
Mexico's new interest in engaging Canada. ${ }^{359}$ The visit was the culmination of a strategy on the part of the Fox Administration to engage the Canadian government to work together on common issues they encountered from a security conscious American government. ${ }^{360}$ The communiqué for the visit reflected Canada's willingness to engage Mexico on a broad agenda:

We recognize the interdependence between prosperous North American economies and security, and will continue to ensure the effective management of our borders, including the sharing of best practices. We will promote greater contact among all relevant Mexican and Canadian agencies in order to ensure effective public safety, while ensuring the free flow of goods that are so important for both countries. ${ }^{361}$

In a few short sentences, the Canadian government had abandoned its traditional reticence to engaging Mexico on a broad cooperation agenda.

The hallmark deliverable of the visit was the announcement of the CanadaMexico Partnership (CMP). A corollary to the U.S.-Mexico Partnership for Prosperity, the CMP marked the first time that Canada committed to engaging Mexico on a cooperative agenda beyond trade. ${ }^{362}$ The tenor of the visit and the announcement of the Canada-Mexico Partnership manifested the adoption of a radically different policy approach to pursuing bilateral relations with Mexico. It signaled that Canada was ready to adopt a broad strategic agenda with Mexico that exceeded the scope of the NAFTA

\footnotetext{
${ }^{359}$ Confidential interview with a former official at the Privy Council Office, dated 2007-09-19.

${ }^{360}$ Part of the strategy involved increasing the frequency of Cabinet-level visits, enhancing the relationship between the two legislatures, and organizing frequent exchanges between business groups [Confidential interview with an official at Secretaría de Relaciones Exteriores, dated 2007-09-18].

${ }^{361}$ Canada, Library and Archives Canada, Paul Martin, "Joint Statement by Canada and Mexico: A commitment to our common future," (Ottawa: 25 October 2004), http://epe.lac-bac.gc.ca/100/ 205/301/prime_minister-ef/paul_martin/06-02-03/www.pm.gc.ca/eng/news.asp@id=296.

${ }^{362}$ The initial Canada-Mexico Partnership created four working groups: sustainable development, housing, human capital, agro-business, and the establishment of public-private partnerships designed to increase investment flows into Mexico. In August 2007, the CMP was expanded to include a Labour Mobility working group, a bilateral security working group, an Environment and Forestry working group [Canada, Department of Foreign Affairs and International Trade, "Canada and Mexico: A Joint Action Plan for 20072008," (Ottawa: 21 August 2007), http://www.dfait-maeci.gc.ca/mexico-city/news/Bilateral\%

20Action\%20Plan\%20final\%2020aug-en.pdf].
} 
relationship. The policy window began to crack open with this shift in Canadian policy. The Martin Government's willingness to engage Mexico on a broad agenda that included an economic development component indicated the willingness of the government to embrace a trilateral framework that included Mexico.

The policy window was forced wide open when President Bush made a working visit to Ottawa and Halifax, between 30 November and 1 December 2004. One PCO official remarked that President Bush came to Ottawa determined to strike a good relationship with Martin. ${ }^{363}$ In Washington, the Martin government was perceived to be more conservative than the Chrétien government; the Bush White House wanted to extend an olive branch and help where it could to mend the rift. ${ }^{364}$ For his part, Prime Minister Martin wanted to demonstrate that he would pursue a better relationship with the Bush Administration than his predecessor. ${ }^{365}$

Although the NAI was not discussed at the table during the Bush-Martin meetings, it was present in the briefing material prepared for the Prime Minister ahead of his April and November 2004 meetings with President Bush. ${ }^{366}$ More importantly, the communiqué released at the end of the visit announced that Canada and the United States would pursue an initiative called the New Partnership in North America (NPNA). The communiqué announced that, "Canada and the United States [will] commit to deepening

\footnotetext{
${ }^{363}$ Confidential interview with a former official at the Privy Council Office, dated 2007-09-19.

${ }^{364}$ Ibid. For example, at their first bilateral meeting in Monterrey, President Bush announced that Canada would be allowed to bid on reconstruction projects in Iraq, even though Canada had been excluded from the initial round of bidding because it had not joined the 'Coalition of the Willing.' The Americans also took a more cooperative stance toward keeping the border open to Canadian beef exports [Brian Knowlton, "U.S. Fence-Mending Includes Iraq Works," International Herald Tribune, January 14, 2004].

${ }^{365}$ See Chapter 4, pages 112-113.

${ }^{366}$ On the Canadian side, the agenda consisted of cattle exports and softwood lumber. On the American side, the issues for discussion included national ballistic missile defense, Iraq, the Middle East and Hugo Chavez. These were all urgent issues that needed the attention of the leaders, more so than the NAI [Confidential interview with a former official at the Privy Council Office, dated 2007-09-19].
} 
our cooperation in North America and in the world. We will both work bilaterally to address Canada-U.S. priorities and continue our close cooperation with Mexico on issues of trilateral importance." ${ }^{367}$ The NPNA was simply a trial balloon that was floated by the two governments signalling the imminent unveiling of the SPP. As a senior State

Department official told the press in Ottawa:

The idea [of the NPNA] being to find ways to accentuate and deepen our cooperation on both security and on trade and commerce and economic issues, recognizing that we've accomplished a lot since 9/11, but recognizing that the wellbeing of our democratic institutions and our prosperity and our open societies still remain at risk and are intimately linked to our security and to our ability to cooperate on security, and that we need to find ways to not only deepen the movement of goods and services across our frontiers, but improve our security while we do that. And what happened today is really a bilateral start for a larger trilateral initiative, really kind of a North American initiative, which will also bring in Mexico. ${ }^{368}$

The decision to include the NPNA as the theme for the meeting communiqué could not have been made without the sign-off from the leaders and their senior officials in the PCO and the NSC. After the political window closed, all that was left was for the three countries to finalize negotiations for the 2005 SPP Summit that occurred in Waco.

\section{$\underline{5.2 \text { The Policy Entrepreneurs }}$}

The opening of the political window in the Fall of 2004 was a necessary step for guaranteeing a spot for the SPP on the decision agenda. Without the emergence of policy entrepreneurs to link problems with solutions, and couple solutions with political

\footnotetext{
${ }^{367}$ Canada, Library and Archives Canada, Paul Martin, "Joint Statement by Canada and the United States on common security, common prosperity: A new partnership in North America," (Ottawa: 30 November 2004), http://epe.lac-bac.gc.ca/100/205/301/prime_minister-ef/paul_martin/06-02-03/www.pm.gc.ca/ eng/news.asp@id=341.

${ }^{368}$ United States, State Department, US INFO, "Background Briefing by a Senior Administration Official on the President's meetings with Prime Minister Martin," (Ottawa: 30 November 2004), http://www.america.gov/st/washfile-english/2004/December/20041201114924ASrelliM0.1756555.html.
} 
opportunities, the existence of an open window would have been insufficient on its own to generate agenda change.

In his work, John Kingdon argues that the opening of a policy window is seized upon by a single policy actor who possesses the entrepreneurial skills required to make the linkages between the three streams and shepherd the initiative through the open window. The research conducted for this thesis, however, reveals that the policy entrepreneurship was not conducted by a single actor. Rather, the research revealed that the entrepreneurial work was performed by teams of government officials in each of the three countries. In other words, the policy entrepreneurship required to move the SPP from the government agenda to the decision agenda in each country was performed by a group of officials who embarked on a collaborative two year effort to design, advocate, and negotiate the SPP.

In Canada, the entrepreneurial team included central agency officials led by Jonathan Fried, Phil Ventura, Chantel Maheu and Greg Goatbe, and their team of officials in the Canada-U.S. Secretariat at the PCO; National Security Advisor Robert Wright; Deputy Secretary to the Cabinet Robert Fonberg and the Director of the Borders Task Force, Graham Flack; the Minister (Political and Public Affairs) at the Canadian Embassy in Washington, Peter Boehm; and several high profile Cabinet Ministers including John Manley, Anne McLellan and David Emerson. ${ }^{369}$ In the United States the team of officials included NSC directors Daniel Fisk and Thomas Shannon; two Deputy National Security Advisors, Gary Edson and Faryer Shirzad; officials at the Department of Commerce; and

\footnotetext{
${ }^{369}$ Jonathan Fried's relationship with Gary Edson, one of the American policy entrepreneurs, opened the door to informal high level discussions between NSC and PCO officials on the NAI. The NAI was first introduced to Edson and other White House officials at a dinner in Washington in late 2002. The dinner was attended by Robert Fonberg, Peter Boehm, and Jonathan Fried.
} 
Cabinet secretaries Tom Ridge and Carlos Gutierrez. In Mexico, the SPP team was led by Eduardo Sojo and Alberto Ortega from Presidencia and Gerónimo Gutierrez at the Mexican foreign ministry.

The identification of these teams of officials is important, insofar as SPP officials who were interviewed for this thesis emphasized the importance of the collaborative work within and between the three countries to develop, promote and negotiate the Security and Prosperity Partnership. No single individual was solely responsible for the policy outcome at Waco. However, in order to generate agenda change and position the SPP high on the decision agenda of all three countries, the involvement and support of the political leaders of the three countries were essential. It is in this context that the policy entrepreneurs contributed to the collaborative effort to promote the SPP in the national capitals.

In Canada, the key to moving the SPP from the government agenda to the decision agenda was to obtain the support of the Prime Minister. Senior PCO officials in the Canada-U.S. Secretariat certainly had the support of Public Safety Minister Anne McLellan and Industry Minister David Emerson; officials at the Department of Foreign Affairs had the support of Foreign Minister Pierre Pettigrew. However, without the support of the Prime Minister, the SPP could not have secured a place on the decision agenda in Canada. In order to obtain Prime Minister Martin's support, the entrepreneurial team had to be able to join the three streams: to link the NAI solution with problems familiar to the Prime Minister and with the political considerations that occupied Martin and his advisors. ${ }^{370}$ The NAI had to be promoted as the best of both worlds to Martin: it

${ }^{370}$ For example, the entrepreneurs were able to relate the NAI's contents to Paul Martin's familiarity with both the Smart Border Declaration and with concerns about Canada's economic competitiveness. Paul 
would add a new element to the security-prosperity paradigm so that he could demonstrate to business leaders and the public that the SPP advanced Canadian economic and social interests. At the same time, the content had to be weak enough so as not to arouse nationalist reaction in a minority government setting. Prime Minister Martin was briefed on the NAI ahead of his bilateral meetings with President Bush in both April and November 2004. ${ }^{371}$ These briefings gave senior Canadian officials a platform to make the necessary linkages between problems, solutions, and political considerations when advocating the SPP. ${ }^{372}$ At the end of the day, the support of Prime Minister Martin was the variable that was most important for the SPP to successfully pass through the open policy window.

A different set of requirements existed for the American entrepreneurial team.

Given that the NAI was a Canadian-driven proposal, the most important task in Washington was to ensure that the NAI remained a priority item on the government agenda. This outcome was obtained largely as a result of the activities of officials at the National Security Council who received the NAI proposal from Canadian officials and brought it under the sponsorship of an NSC-led interagency group. Indeed, as a prerequisite to obtaining political take-up, the NAI had to pass through the NSC committee system. ${ }^{373}$ Its Principals', Deputies', and Policy Coordinating Committees had the ability to pull together senior political appointees across the Executive Branch in support of the NAI. Without this effort by the American entrepreneurs to place the NAI

Martin had been exposed to both of these issues while he served as Minister of Finance. In fact, the Smart Border Declaration had originated in discussions between Martin and U.S. Treasury Secretary Paul O'Neill in October 2001. It was also easy for Martin to relate to the need to pursue a framework that paired security with cross-border trade facilitation, since he had grown up in the border town of Windsor, Ontario.

${ }^{371}$ Confidential interview with a former official at the Privy Council Office, dated 2007-09-19.

${ }^{372}$ PCO officials confirmed that it did take some convincing in order to garner the support of the Prime Minister [Confidential interview with a former official at the Privy Council Office, dated 2007-09-19].

${ }^{373}$ Confidential interview with an official of the United States Government, dated 2007-12-13. 
on the NSC agenda, it would have been impossible to generate cooperation from U.S.

Executive Branch departments in order to move the NAI to the decision agenda at Waco.

When the policy window opened in November 2004, the team of American entrepreneurs had to bring the streams together for President Bush and his political staff. After the election, President Bush realized the need to repair the damage to the United States' relationships with Canada and Mexico caused by the Iraq war. As a policy option, the NAI presented the perfect opportunity to pursue a positive and cooperative engagement with both neighbours, while demonstrating Bush's commitment to securing America's borders. ${ }^{374}$ Since security had become such a politicized and partisan issue in Washington, the Administration had to show that it could work constructively with Canada and Mexico on the border. ${ }^{375}$ In this highly political setting, the Bush Administration had to be seen as advancing security cooperation along America's borders. Combined with the rising importance of Hispanic issues in Washington politics, White House political staff recognized the need to remain engaged on the border file. ${ }^{376}$ The first set of linkages that had to be made involved the inclusion of Mexico in a trilateral framework. The policy and politics streams were joined for the President by demonstrating that the NAI prosperity pillar advanced the goal of developing poorer regions of Mexico; a theme that resonated on both the congressional and White House agendas. ${ }^{377}$ In addition, the entrepreneurs had to identify the opportunity to use the NAI's

\footnotetext{
${ }^{374}$ The relationship between President Bush and Prime Minister Chrétien had deteriorated in the run-up to the war in Iraq and had never really recovered. The Fox Administration had been forthcoming about working with the United States on border issues post 9/11, and so there was interest in the White House for pursuing a trilateral initiative that would benefit President Fox [Confidential interview with an analyst at the Center for Strategic and International Studies, dated 2007-10-12].

${ }^{375}$ Confidential interview with an official at the Department of Foreign Affairs and International Trade, dated 2007-10-02.

${ }^{376}$ Ibid.

${ }^{377}$ See Chapter 4, pages 107-109.
} 
prosperity agenda as an incentive to resolve the problem of improving Mexican security cooperation with the U.S. The Bush Administration had to be convinced that the processdriven NAI framework would allow the President to appeal to the Hispanic constituency with a positive outreach initiative to Mexico, without generating criticism from opponents of immigration reform or extending risk-management based programs to the southern border.

The American entrepreneurs also had to demonstrate the attractiveness of a framework that accelerated progress on existing initiatives while avoiding the introduction of new substantive content that would arouse the interest of Congress or stoke the fears of the American public over deepening continental integration. ${ }^{378}$ Once the President and his staff accepted the NAI, and given the earlier work of NSC officials in securing the NAI on the White House agenda, the path became clear for the NAI to move to the policy frontburner in Washington. Since the policy development work had been done long before the streams were coupled in 2004, the SPP suddenly became a ready initiative to roll out as a presidential announceable for the Waco Summit.

In Mexico, there was a more limited need for the emergence of policy entrepreneurs to bring the streams together since the NAI had always remained on the decision agenda of President Fox's Administration. Fox and his officials in Presidencia had consistently pursued a strategy to create a North American cooperation agenda. Indeed, Fox himself emerged as a powerful advocate for advancing the SPP as a viable policy option for North America. In October 2004, in a speech to the Parliament of Canada, he told lawmakers, "The time has come to reflect on the best way to build a new community of North America. I am also convinced that Canada and Mexico have much

${ }^{378}$ See Chapter 3, page 81 . 
to contribute to the design and operation of this regional co-operation and integration scheme." 379 Prior to the launch of the SPP, his officials at Presidencia had worked hard to translate this vision into policy through initiatives such as the Partnership for Prosperity and the Canada-Mexico Partnership.

In all three countries, the role performed by these teams of policy entrepreneurs was critical for generating agenda change. Without their ideas, issue-familiarity, advocacy skills, political acumen, and the access of these officials to their national leaders, it would have been very difficult to couple developments in the problem stream with the NAI policy alternative when events in the politics stream opened the policy window. The results of this policy entrepreneurship were evident. The first sign that the SPP had moved to the decision agenda was the announcement of the New Partnership in North America in Ottawa. There was no turning back once the leaders committed themselves publicly to creating this new framework agreement for managing the North American relationship. Soon thereafter, it was announced that President Bush would host Prime Minister Martin and President Fox in Waco to roll out the North American Initiative as the Security and Prosperity Partnership of North America. This agenda change was made possible by the stewardship of the policy entrepreneurs who skillfully brought the three streams together for their respective national leaders.

\footnotetext{
${ }^{379}$ Jeff Sallot, "Mexico's Fox Aims to Fend Off China's Challenge; Wants Canada, U.S. to Help Protect Jobs," The Globe and Mail, October 26, 2004, sec. A.
} 


\section{CONCLUSION}

The movement of the Security and Prosperity Partnership from the policy backburner to the top of the decision agenda at Waco was a result of agenda change triggered by the coupling of the three streams by policy entrepreneurs in Canada, the United States, and Mexico when the window of opportunity opened in Fall 2004. In the problem stream, four specific problems related to the management of the North American relationship influenced the setting of the government agendas of all three countries. The existence of a budget constraint in the United States and Mexico required the adoption of a process-driven framework initiative.

The adoption of an architecture-centric model satisfied the problems that structured the agenda: the incomplete NAFTA agenda required the pressure created by incorporating initiatives under a management-from-the-centre framework with new reporting requirements and deliverables; the challenge of thickening American borders required a new umbrella framework that brought security and prosperity agencies together; the problem of Canadian reluctance to including Mexico in a North American agenda that extended beyond trade was resolved through adoption of the two-speed model.

Autonomous events in the politics stream also conditioned the scope of the governments' agendas. Public antipathy toward deepening North American integration and the preferences of elected officials and their appointees precluded the pursuit of anything other than an uncontroversial and incremental framework initiative that was incremental and built on existing intergovernmental cooperation. The inclusion of Mexico satisfied the political priorities of American and Mexican politicians; the 
management-from-the-centre framework skirted obstacles that would have likely arisen from interagency turf battles; the SPP framework's recognition of the indivisibility of security and prosperity was sufficient to rally the support of private sector interests to the coalition of government actors who advocated the SPP. In short, the agenda-setting process in the politics and problem stream explain why a process-driven initiative ascended to the top of the government agenda in Mexico, Canada, and the United States.

The process of alternative specification in the policy stream yielded a processdriven policy option: the North American Initiative. The long period of gestation, debate and dissemination of policy options between 2002 and 2005 produced consensus among members of the policy network around the general principles of a North American initiative: it had to be trilateral; it had to balance security and prosperity considerations; it had to pay heed to pace and sequencing. The NAI model incorporated all three of these principles, but diverged from the preferences of the private sector with respect to populating the content of the NAI. Conditions in the policy stream were not amenable to the pursuit of content-driven initiatives. Instead, conditions favoured the re-packaging of ongoing bilateral and trilateral initiatives under a new framework. These constraints coincided with the opportunities and constraints found in the government agenda.

When the policy window opened in Fall 2004, the NAI was the policy alternative available to be linked with the problems and political considerations that structured each country's agenda. Policy entrepreneurs in all three countries emerged when the window opened to bring the three streams together and secure a place for the SPP on the decision agenda at Waco. In this way, agenda change hastened the emergence of a new architecture for managing the North American relationship. 
The decision to announce the NAI at the Waco Summit as the Security and Prosperity Partnership represented the culmination of a process of policy change explained through the analytical framework provided by the multiple streams model. The model, which was focused on explaining pre-decision stages of the policy process, allowed for an original and critically important hypothesis to emerge: that the structure of the government agenda produced in the politics stream and the constraints that existed for content-driven policy options in the policy stream resulted in a deliberate decision by government officials in the three countries to design the SPP as a process-driven initiative.

Accepting the SPP as a process-driven initiative fundamentally alters the contours of the debate on the SPP. It suggests that the SPP should no longer be analyzed as a failure to achieve new content-driven initiatives for North America. Instead, the SPP should be understood as an intentional decision by policy actors in all three countries to design new architecture for the continental relationship. This architecture is threefold: it expanded the management-from-the-centre framework to a broad range of policy sectors, through the creation of new reporting requirements around annual ministerial and leaders' meetings; it created a two-speed model for governing Mexico's participation in a broad policy framework; and it entrenched the paradigm of the co-dependency between security and prosperity as the overarching framework for organizing bilateral and trilateral cooperation between the three countries.

Although this analysis ends with the announcement of the SPP at Waco, subsequent events manifested the power of the SPP to continually augment the architecture for North America. At the 2006 Cancun Summit, the three leaders announced the creation of the North American Competitiveness Council (NACC); the 
NACC was created to review and prioritize the ongoing initiatives that were repackaged under the SPP framework. ${ }^{380}$ Ahead of the Montebello Summit, another addition to architecture was announced: the establishment of an Emergency Management Council, which brought together senior emergency management officials in all three countries for the first time. ${ }^{381}$ Even the major overlays of the Cancun and Montebello summits were more about process than substance: in 2006 , the hallmark priorities included the drafting of a comprehensive Avian and Pandemic Influenza Preparedness Plan, and cooperation on clean energy technologies, conservation, and market facilitation. ${ }^{382}$ In 2007, the hallmark priorities included a trilateral science and technology cooperation agreement on clean energy; the Regulatory Cooperation Framework; a new Intellectual Property Action Strategy; the leaders also announced a new plan for enhancing food and consumer product safety. ${ }^{383}$ Lastly, the summits themselves have become the most important addition to the architecture of North American relations.

When the SPP was launched at Waco, there was no intention of organizing subsequent leaders' summits. At the suggestion of the newly elected Canadian Prime Minister, Stephen Harper, it was decided that annual Leaders' summits would be organized. ${ }^{384}$ The decision to make these summits permanent ensured that the

\footnotetext{
${ }^{380}$ White House, "President Bush, President Fox of Mexico, and Prime Minister Harper of Canada in Press Availability," (Fiesta Americana Condesa Cancun Hotel: 31 March 2006), http://www.whitehouse.gov/ news/releases/2006/03/20060331-4.html.

${ }^{381}$ The Council was a byproduct of the trilateral consultations to draft the North American Pandemic Influenza Preparedness Plan [Canada, SPP, "Joint Statement: Prime Minister Harper, President Bush, President Calderon North American Leaders' Summit," (Montebello: 21 August 2007), http://www.montebello2007.gc.ca/statement-declaration-eng.html].

${ }^{382}$ United States, White House, "The Security and Prosperity Partnership of North America: Progress," (31 March 2006), http://www.spp.gov/pdf/security_and_prosperity_partnership_of_north_america_ statement.pdf

${ }^{383}$ Canada, SPP, "Joint Statement: Prime Minister Harper, President Bush, President Calderon North American Leaders' Summit," (Montebello: 21 August 2007), http://www.montebello2007.gc.ca/statementdeclaration-eng.html.

${ }^{384}$ Confidential interview with a former official at the Privy Council Office, dated 2007-08-14.
} 
management-from-the-centre framework would be perpetuated, since central agencies set reporting requirements timed for each summit meeting and the ministerial meetings that preceded it. Understanding the SPP as creating new architecture also highlights two of the most important strategic outcomes from the SPP process: the adoption of the SPP framework established a series of interagency networks coordinated by each country's central agency that created a permanent process for considering the North American implications of initiatives across a broad range of policy sectors for the first time. The adoption of the SPP framework was also the catalyst for strengthening the bilateral relationship between Canada and Mexico by expanding bilateral cooperation to policy sectors that had previously been off-limits. ${ }^{385}$

These strategic implications of the architecture created by the SPP hint at the possibilities that exist for future scholarship on the subject by recasting the interpretation of the SPP as new architecture, rather than as the failure to implement substantive initiatives. Areas for research could include: assessing the effectiveness of the two-speed model; analyzing whether presenting the SPP as a process-driven initiative alters the critique that business groups were included in the process while civil society were excluded; exploring whether the interagency process in Canada, the United States or Mexico has pursued a more North American outlook as a result of the SPP; and testing the hypothesis that the SPP served as a catalyst for bridging the Canada-Mexico divide. Each of these questions is likely to generate fascinating work to augment this initial foray to understanding and explaining the origins of the SPP.

\footnotetext{
${ }^{385}$ This is best manifest by the expansion of the Canada-Mexico Partnership in August 2007 [see Chapter 5, page 127, footnote 359]. The security relationship between Canada and Mexico is completely new. For the first time, there is a bilateral security working group managed by Public Safety Canada and CISEN; political-military talks managed by the Department of National Defence and the Mexican Ministry of Defence, a security consultations group managed by DFAIT and SRE. None of these forums existed prior to the SPP.
} 
The architecture created by the SPP will continue to evolve. In 2007, for example, the Canadian hosts of the Montebello Summit billed the meeting as a "North American Leaders' Summit." This new summit format permitted the leaders to discuss an agenda broader than the SPP. Even if the SPP name eventually disappears from the lexicon of the North American relationship, its legacy, the underlying architecture that it created, will persist well into the future. This new architecture will persist precisely because the SPP was never tied to specific content, but rather to process. The SPP was about initiating a continental renovation to upgrade the North American architecture for managing the new realities of an increasingly interdependent continent. 


\section{BIBLIOGRAPHY}

Abbott, Jeffrey D. and Robert T. Moran. Uniting North American Business. Burlington: Buttersworth-Heinemann, 2002.

Ackleson, Jason, and Justin Kastner. "The Security and Prosperity Partnership of North America." The American Review of Canadian Studies 36, No. 2 (Summer 2006): 207-232.

Anderson, C.V., ed. NAFTA Revisited. New York: Nova Science Publishers Inc., 2003.

Anderson, Greg, and Christopher Sands. "Negotiating North America: The Security and Prosperity Partnership." Hudson Institute. White Paper. Fall 2007.

Andreas, Peter, and Thomas J Bierstaker, eds. The Rebordering of North America: Integration and Exclusion in a New Security Context. New York: Routledge, 2003.

Bell Canada Enterprises. "Remarks by Michael J. Sabia, President and CEO of BCE, 'North American Competitiveness: Smart Technologies, Smart Borders, Smart Business.'” Montreal: 18 September 2006. http://www.bce.ca/data/documents/speech_north_american_comp_en.pdf

Boulden, Jane, and Monica Serrano. “Guest Editors' Introduction.” International Journal 61, No. 3 (Summer 2006): 529.

Brown University. Watson Institute. "Transcript: the Re-bordering of North America: Integration or Exclusion after 9/11?" Providence: February 5, 2002. http://www.watsoninstitute.org/news_detail.cfm?id=38

Butler, Don. “Whose Security?” Ottawa Citizen, August 18, 2007, sec. B.

Campbell, Bruce. "More than Jellybeans: The SPP Regulatory Framework Agreement and its Impact on Chemical Regulations." Canadian Centre for Policy Alternatives. North American Deep Integration Series 1,1 (September 2007). http://www.policyalternatives.ca/documents/National_Office_Pubs/2007/More_T han_Jellybeans.pdf

Can-Am Border Trade Alliance. "April 2005 Ottawa Conference Summary Highlights." Ottawa: 24-25 April 2005. http://www.canambta.org/ott_2005_summary1.pdf

Can-Am Border Trade Alliance. "April 2004 Ottawa Conference Summary Highlights." http://www.canambta.org/ott_2004_summary.pdf

Canada. Department of Finance. Canada's New Government: Turning a New Leaf. Ottawa: Department of Finance, 2006. 
Canada. Department of Finance. "Speech by Honourable John Manley Deputy Prime Minister and Minister of Finance to the Canadian-American Business Council," Washington, D.C.: 27 September 2002. http://www.fin.gc.ca/news02/02076e.html

Canada. Department of Foreign Affairs and International Trade. A Role of Pride and Influence in the World: Canada's International Policy Statement. Ottawa: Department of Foreign Affairs, 2005. http://geo.international.gc.ca/cippic/ips/overview_en_aspx.

Canada. Department of Foreign Affairs and International Trade. Access to Information Disclosure. "Security and Prosperity Ministerial Meeting [minutes]." Ottawa: 23 February 2007. http://www.corbettreport.com/cache/spp.pdf

Canada. Department of Foreign Affairs and International Trade. "Canada and Mexico: A Joint Action Plan for 2007-2008." Ottawa: 21 August 2007. http://www.dfaitmaeci.gc.ca/mexico-city/news/Bilateral\%20Action\%20Plan\%20final\%2020augen.pdf

Canada. Department of Foreign Affairs and International Trade. "Smart Borders Action Plan Status Report." 14 December 2004. http://geo.international.gc.ca/canam/main/border/status-en.asp

Canada. Embassy of Canada in the United States. "Joint Meeting of the Canadian Chamber of Commerce and the U.S. Chamber of Commerce." Washington DC: 31 March 2004. http://canadianembassy.org/homepage/040331-en.asp

Canada. External Advisory Committee on Smart Regulation. Smart Regulation: A Regulatory Strategy for Canada. Ottawa: September 2004.

Canada. Library and Archives Canada. Prime Minister of Canada Paul Martin. "Address by Prime Minister Martin on the Occasion of his visit to Washington." Washington, D.C.: 29 April 2004. http://epe.lac-bac.gc.ca/100/205/301/ prime_minister-ef/paul_martin/06-02-03/www.pm.gc.ca/eng/news.asp@id=192

Canada. Parliament. House of Commons. Standing Committee on Foreign Affairs and International Trade. Partners in North America: Advancing Canada's Relations with the United States and Mexico. $37^{\text {th }}$ Parl. $2^{\text {nd }}$ Sess. Ottawa: December 2002.

Canada. Parliament. House of Commons. Standing Committee on Foreign Affairs and International Trade. Subcommittee on International Trade, Trade Disputes, and Investment. Evidence. $37^{\text {th }}$ Parl. $1^{\text {st }}$ Sess. 18 October 2001.

Canada. Parliament. House of Commons. Standing Committee on Foreign Affairs and International Trade. Evidence. $37^{\text {th }}$ Parl. 1st Sess. 20 November 2001. 
Canada. Parliament. House of Commons. Standing Committee on Foreign Affairs and International Trade. Evidence. $39^{\text {th }}$ Parl. $1^{\text {st }}$ Sess. 24 April 2007.

Canada. Parliament. Senate. Standing Committee on Foreign Affairs. Evidence Issue 2. $37^{\text {th }}$ Parl. $2^{\text {nd }}$ Sess. 5 February 2003.

Canada. Parliament. Senate. Standing Committee on Foreign Affairs. Proceedings Issue 13. 37 ${ }^{\text {th }}$ Parl. $2^{\text {nd }}$ Sess. 1 April 2003.

Canada. Parliament. Senate. Standing Committee on National Security and Defence. Evidence Issue 12. $37^{\text {th }}$ Parl. $2^{\text {nd }}$ Sess. 17 March 2003.

Canada. Parliament. Senate. Standing Committee on National Security and Defence. Evidence Issue 1. $37^{\text {th }}$ Parl. $3^{\text {rd }}$ Sess. 23 February 2004.

Canada. Parliament. Senate. Standing Committee on National Security and Defence. Evidence Issue 26. $38^{\text {th }}$ Parl. $1^{\text {st }}$ Sess. 17 October 2005.

Canada. Prime Minister. "Prime Minister Announces Changes in the senior ranks of the Public Service." Ottawa: 23 March 2006. http://pm.gc.ca/eng/ media.asp? category $=1 \& i d=1069$

Canada. Policy Research Initiative. Canada-U.S. Regulatory Cooperation Symposium Report. Ottawa: 29 October 2004. http://www.policyresearch.gc.ca/doclib/ NAL_SR_reg\%20coop\%20Canada-US_200410_e.pdf

Canada. SPP. "Joint Statement: Prime Minister Harper, President Bush, President Calderon North American Leaders' Summit." Montebello: 21 August 2007. http://www.montebello2007.gc.ca/statement-declaration-eng.html

Canada. Treasury Board Secretariat. "RPP Overview for Parliamentarians 2007-2008: International Affairs." http://www.tbs-sct.gc.ca/wgpp-prpg/pa-ds-eng.aspx? $\mathrm{Rt}=991 \& \mathrm{~Pa}=1092$

Canadian Chamber of Commerce. "Trilateral Agreement Welcomed By Business." Ottawa: 23 March 2005. http://www.barriechamber.com/broadcast/enews/ Newsletter/05-03-23CCC.pdf

Canadian Council of Chief Executives. "Canada and Mexico Building a Shared Future for in North America, Notes for an Address to the Mexico Business Summit by Thomas d'Aquino." Veracruz: 20 September 2004. http://www.ceocouncil.ca/ publications/pdf/613fd58b4495b89c97a4dfe304f1e069/Notes_for_ Remarks_by_Thomas_d_Aquino_to_the_Mexico_Business_Summit_September _20_2004.pdf

Canadian Council of Chief Executives. New Frontiers: Building a $21^{\text {st }}$ Century CanadaUnited States Partnership in North America. Ottawa: April 2004. 
Canadian Council of Chief Executives. Security and Prosperity Toward a New CanadaUnited States Partnership in North America. Ottawa: January 2003.

Canadian Industrial Transportation Association. Coalition for Secure and Trade-Efficient Borders. "Letter to the Prime Minister." 13 November 2001. http://www.citaacti.ca/english/View.asp? $\mathrm{x}=338 \& \mathrm{mp}=326$

Canadian Industrial Transportation Association. Coalition for Secure and Trade-Efficient Borders. "Steering Committee." http://www.citaacti.ca/english/ View.asp? $\mathrm{x}=339 \& \mathrm{mp}=326$

Canadian Manufacturers and Exporters' Association. "Statement of Principles- Coalition for Secure and Trade-Efficient Borders: Rethinking our Borders." http://www.cme-mec.ca/national/documents/bordercoalition.pdf

Canadian Manufacturers and Exporters' Association. Coalition for Secure and TradeEfficient Borders. Rethinking our Borders: A Plan of Action. 3 December 2001. http://www.cme-mec.ca/pdf/planforaction.pdf

Canadian Trucking Alliance. "Canadian Trucking Alliance Welcomes Bush-Martin Security/Prosperity Framework.” Ottawa: 30 November 2004. http://www.cantruck.com/news/news/2004/041130.htm

Canadian Trucking Alliance. News Release. "Joint Statement: Enhancing Security and Commercial Traffic Flow at the Peace Bridge.” Buffalo: 8 December 2004. http:///www.cantruck.com/news/news/2004/041208.htm

Celorio, Marcela. "The Current Debate Regarding the SPP: Security and the Integration of North America." Center for North American Studies. White Paper Washington: American University, 2006.

Cellucci, Paul. Unquiet Diplomacy. Toronto: Key Porter Books, 2005.

Centro de Investigación y Docena Económicas, Consejo Mexicano de Asuntos Internacionales, and The Chicago Council on Foreign Relations. Global Views 2004: Comparing Mexican and American Public Opinion and Foreign Policy. 2004. http://www.ccfr.org/globalviews2004/sub/pdf/Global_Views_2004 _US_Mexico.pdf

C.D. Howe Institute. Archives. Events and Activities 2005. "Prospects for Canada-U.S. Relations, Jonathan T. Fried." 15 March 2005. http://www.cdhowe.org/ display.cfm? page $=$ events $\&$ yearToUse $=2005 \&$ archive $=$ yes

Chase, Steve. "Canada, U.S., Mexico reject customs union as next step." The Globe and Mail, October 8, 2003, sec. B. 
Clarkson, Stephen. "Smart Borders and the Rise of Bilateralism." International Journal 61, No. 3 (Summer 2006): 588-610.

Clarkson, Stephen, Sarah Davidson Ladly, and Carleton Thorne. "De-institutionalizing North America: NAFTA's committees and working groups." Third EnviReform Conference. 8 November 2002. http://www.envireform.utoronto.ca/conference/ nov2002/clarkson-paper2.pdf

CNN.com. Transcripts. Lou Dobbs Tonight, Aired June 21, 2006. http://transcripts.cnn.com/TRANSCRIPTS/0606/21/ldt.01.htm

Commission for Environmental Cooperation. "North American Marine Protected Areas Network." http://www.cec.org/programs_projects/conserv_biodiv/ project/index.cfm?projectID=19

Condon, Bradly J., and Tapen Sinha. Drawing Lines in the Sand and Snow. Armonk, NY: ME Sharp, 2003.

Conference Board of Canada. In Search of a New Equilibrium in the Canada-U.S. Relationship. Ottawa: February 2005.

Couchiching Online. "Renee St. Jacques: Sovereignty or Standard of Living: is there a trade off?" $72^{\text {nd }}$ Annual Summer Conference. 7-10 August 2003. http://www.couch.ca/history/index.html.

Council of the Americas. A Compact for North America: A Strategy for Building Competitiveness within North America. April 2005. http://www.as-coa.org/files/PDF/pub_151_92.pdf

Council of the Americas. Findings of the Public/Private Sector Dialogue on the Security and Prosperity Partnership. Louisville: 10-11 January 2006. http://www.uschamber.com/NR/rdonlyres/etwlppaptichktcxxaqzts6f56taykewnjul 746yrgj4b7vdr7ojki6sgs35uvybp4rghgzf3jbcpj3zpyxk5z77xwc/09LouisvilleKYS PPReport.pdf

Council of the Americas. Press Release. "North American Business Committee Releases Report on the Security and Prosperity Partnership." Washington: 16 March 2006. http://www.as-coa.org/files/PDF/pub_136_80.pdf

Council of Canadians. Crossing the Line: A Citizen's Inquiry on Canada-U.S. Relations. Ottawa: The Council of Canadians, 2005.

Courchene, Thomas J., Donald Savoie, and Daniel Schwanen, eds. The Art of the State, Vol. II: Thinking North America. Institute for Research on Public Policy: Montreal, 2004. 
d'Aquino, Thomas. "Beyond Free Trade: A Canada-United States Partnership for Security and Prosperity, Notes for remarks in Dallas, Tuscon, Phoenix, Cleveland, and Buffalo." 24 February to 3 March 2005. http://www.ceocouncil.ca/en/ view/?document_id=393\&type_id=3

d'Aquino, Thomas. "Towards a New North America." Viewpoint Americas 2, No. 2. New York: Council of the Americas, 16 March 2004. http://www.ceocouncil.ca/en/view/?document_id=308\&type_id=3

Dallas, Paloma. "Thinking outside the Box: With Courage and Competence, Carlos Gutierrez Guides Kellogg's." Hispanic Magazine.com. March 2002. http://www.hispaniconline.com/magazine/2002/march/features/kelloggs.html

Daudelin, Jean and Daniel Schwanen, eds. Canada Among Nations: What Room for Manoeuvre? Montreal: McGill-Queen's University Press, 2008

Davidow, Jeffrey. The U.S. and Mexico: The Bear and the Porcupine. Princeton: Markus Wiener, 2004.

Davis, Lynn E. “Organizing for Homeland Security.” RAND Corporation. RAND Issue Paper (2002). http://rand.org/pubs/issue_papers/IP220/index2.html

De Lourdes Dieck-Assad, Maria. "Is there a NAFTA plus?" International Journal 58 no. 3 (Summer 2003): 433-442.

Deutch, John M., Chris Hornbarger, Arnold Kanter, and Brent Scrowcroft. "Strengthening the National Security Interagency Process." Chapter 10. Keeping the Edge: Managing Defense for the Future. Ashton B. Carter and John P. White, eds. Cambridge: The MIT Press, 2001.

DeYoung, Karen. “A Fight Against Terrorism—and Disorganization." Washington Post, August 9, 2006, sec A.

Derbez, Luis. "Competitividad y Diplomacia." Instituto Mexicano para la Competitividad. http://www.imco.org.mx/ar40.php

Díez, Jordi, ed. Canadian and Mexican Security in the New North America: Challenges and Prospects. Montreal: McGill-Queen's University Press, 2006.

Dobson, Wendy. "Shaping the Future of North American Economic Space." C.D. Howe Institute. The Border Papers, No. 162 (April 2002).

Doern, Bruce G., ed. How Ottawa Spends 2004-2005: Mandate Change and Continuity in the Paul Martin Era. Montreal: McGill-Queens University Press, 2004.

Doern, Bruce G., and Brian W. Tomlin, Faith and Fear: the Free Trade Story. Toronto: Stoddart, 1992. 
Doern, Bruce G., Leslie A. Pal, and Brian W. Tomlin, eds. Border Crossings: The Internationalization of Canadian Public Policy. Toronto: Oxford University Press, 1996.

Donahue, Thomas. "Opening Remarks: U.S.-Canada Business Dialogue." United States Chamber of Commerce. Washington: 31 March 2004. http://www.uschamber.com/press/speeches/2004/040331tjd_canada.htm

Downs, André, "North American Integration: Challenges and Potential Responses." Horizons 7, No. 1 (June 2004): 4-8.

Draper, Robert. Dead Certain: the Presidency of George W. Bush. New York: Free Press, 2007.

Dymond, William, and Michael Hart. "Canada and the Global Challenge: Finding a Place to Stand." C.D. Howe Institute. The Border Papers, No. 180 (March 2003).

Dymond, William, and Michael Hart. Common Borders, Shared Destinies: Canada, the United States, and Deepening Integration. Ottawa: Centre for Trade Policy and Law, 2001.

Evans, Paul. "Canada, meet global China." International Journal 61, No. 2 (Spring 2006): 283-297.

Fagan, Drew. "Delegation, Expectations large for Washington Visit." The Globe and Mail, April 29, 2004, sec. A.

Fox, Vicente. Revolution of Hope: the Life, Faith and Dreams of a Mexican President. New York: Penguin Group, 2007.

Galloway, Gloria. "Canadians oppose war in Iraq without UN; Only 15 per cent willing to endorse; unilateral U.S. invasion, poll says." The Globe and Mail, January 18, 2003 , sec. A.

Goldfarb, Danielle, and William Robson. "Risky Business: U.S. Border Security and the Threat to Canadian Exports." C.D. Howe Institute. The Border Papers, No. 177 (March 2003).

Goldfarb, Danielle. "The Road to a Canada-U.S. Customs Union: Step-by-Step or in a Single Bound?" C.D. Howe Institute. The Border Papers, No. 184 (June 2003).

Goldenberg, Eddie. The Way it Works: Inside Ottawa. Toronto: McClelland \& Stewart Ltd., 2006. 
Gotlieb, Allan. "A North American Community of Law." Presentation to Borderlines Conference. Washington, D.C.: Wilson Center, 27 February 2003. http://www.wilsoncenter.org/events/docs/gotlieb.doc

Granatstein, J.L. "A Friendly Agreement in Advance: Canada-US Defense Relations Past, Present, and Future." C.D. Howe Institute. The Border Papers, no. 166 (June 2002).

Greenstein, Fred, ed. The George W. Bush Presidency: An Early Assessment. Baltimore: John Hopkins University Press, 2003.

Gregg, Gary L. and Mark J. Rozell, eds. Considering the Bush Presidency. New York: Oxford University Press, 2004.

Gutierrez, Gerónimo. “America del Norte Retos y Proximo Pasos.” Instituto Mexicano para la Competitividad (2005). http://www.imco.org.mx/ar43.php

Hakim, Peter and Robert E. Litan, eds. The Future of North American Integration Washington: Brookings Institution, 2002.

Hale, Geoffrey E. "Sharing a Continent: Security, Insecurity, and the Politics of 'Intermesticity." Canadian Foreign Policy 12, No. 3 (2005/2006): 31-43.

Hart, Michael. "Steer or Drift? Taking Charge of Canada-U.S. Regulatory Convergence." C.D. Howe Institute. The Border Papers, no. 229 (March 2006).

Healy, Teresa. "Deep Integration in North America: Security and Prosperity for Whom?" Research Paper \#42. Ottawa: Canadian Labour Congress, 20 February 2007.

Hillmer, Norman. "Are Canadians anti-American?" Policy Options (JulyAugust 2006): 63-65.

Howlett, Michael and M. Ramesh. Studying Public Policy: Policy Cycles and Policy Subsystems. $2^{\text {nd }}$ ed. Toronto: Oxford University Press, 2003.

Hufbauer, Gary, and Jeff Schott. "The Prospects for Deeper North American Economic Integration: A US Perspective." C.D. Howe Institute. The Border Papers, no. 195 (January 2004).

Huelsemeyer, Axel. "Toward Deeper North American Integration: A Customs Union?" Canadian-American Public Policy Occasional Paper No. 59. Canadian-American Centre, University of Maine (2004).

Ignatius, David. "How Bush Stumbled On Steel." The Washington Post, May 17, 2002, sec. A. 
Independent Taskforce on the Future of North America. Building a North American Community. New York: Council on Foreign Relations, May 2005.

Institute for Research on Public Policy. "North American Integration: Trade, Migration, and Security." Ottawa: 1-2 April 2004. http://www.irpp.org/events/index.htm

Institute for Research on Public Policy. "Remarks by the Under Secretary for North America, Gerónimo Gutierrez, at the Conference: North American Integration: Migration, Trade and Security." Ottawa: 2 April 2004. http://www.irpp.org/events/

International Monetary Fund. World Economic Outlook-Advancing Structural Reforms. Washington: IMF, April 2004.

International Monetary Fund. World Economic Outlook-Globalization and External Imbalances. Washington: IMF, April 2005.

John Birch Society. Position Statement. "North American Union \& Security and Prosperity Partnership." http://www.jbs.org/node/915

Judicial Watch. Freedom of Information Request, dated 10 August 2007. "Memorandum from Secretary Chertoff, Re: Implementation of Security and Prosperity Partnership," 22 September 2005. http://www.judicialwatch.org/archive/2007/dhs06-880reSPP14Mar07_001.pdf

Kingdon, John W. Agendas, Alternatives, and Public Policies. New York: Longman, 2003.

Knowlton, Brian. "U.S. Fence-Mending Includes Iraq Works." International Herald Tribune, January 14, 2004.

Koring, Paul. "Hillary Clinton unbowed; Border tale a hoax but senator stands; by her comments about security." The Globe and Mail, January 10, 2003, sec. A.

Krauss, Clifford. "Divergent Paths: Canada Breaks with U.S. Over Missile Shield." New York Times, February 27, 2005, sec. A.

Kumar, Martha Joynt. Managing the President's Message. Baltimore: John Hopkins University Press, 2007.

Laidler, David, and William B.P. Robson. "No Small Change: The Awkward Economics and Politics of North American Monetary Integration." C.D. Howe Institute. The Border Papers, No. 166 (June 2002). 
Lagassé, Philippe, and Joel L. Sokolsky. "Suspenders and a Belt: Perimeter and Border Security in Canada-U.S. Relations." Canadian Foreign Policy 12, No. 3 (2005/2006): 15-29.

Lindgren, April. "Fox will address trade issues with Chrétien." The Montreal Gazette, August 22, 2000, sec. B.

Macrory, Patrick. "NAFTA Chapter 19: A successful Experiment in International Trade Dispute Resolution." C.D. Howe Institute. The Border Papers, No. 168 (September 2002).

Manley, John. "The future of North America." International Journal 60, No. 2 (Spring 2005): 497-508.

Mann, Catherine L. "This is Bangalore Calling: Hang up or Speed Dial?" Federal Reserve Bank of Cleveland. 15 January 2005. http://www.iie.com/publications/papers/mann0105.pdf

Martin, Pierre. "The Mounting Costs of Securing the 'Undefended' Border." Policy Options (July - August 2006): 15-18.

McCarthy, Shawn. "Dhaliwal joins chorus in his caucus against Bush; First cabinet minister to slam U.S. leader calls President failed statesman over Iraq." The Globe and Mail, March 20, 2003, sec. A.

McCarthy, Shawn. "Foreign Affairs Gets Top Guns; Mandarin Shuffle Seen as Shoring Up Department due to Tensions with the United States." The Globe and Mail, 12 April 2003, sec. A.

McGowan, David. "The prospects of a North American project: The 72nd Annual Conference of the Couchiching Institute on Public Affairs." International Journal 58, no. 3 (Summer 2003): 415-418.

McKenna, Barrie. "Canada-U.S. Relations Seen Getting Worse; Rising Protectionism in the U.S. and Election Year Angst Over Foreign Outsourcing Cited." The Globe and Mail, April 20, 2004, sec. B.

McKune, Elizabeth, Frederick C. Smith, and Alan G. Whittaker. The National Security Policy Process: the National Security Council and the Interagency System (Research Report, April 2007 Annual Update). Washington, D.C.: Industrial College of the Armed Forces, National Defense University, U.S. Department of Defense. http://www.ndu.edu/icaf/NSC_Report_2007_FINAL-20_April.pdf

Méndez, José Luis. "Las Oficinas Presidenciales en Mexico y Estados Unidos 19802005: un estudio comparativo." Paper Presented to X Congreso Internacional del CLAD sobre la Reforma del Estado y de la Administración Pública. Santiago, Chile: 18-21 October 2005. http://www.clad.org.ve/fulltext/0053179.pdf 
Mexico. H. Congreso de la Unión. Cámara de Diputados. Publicaciones. "Gabinete Presidencial: Eduardo Sojo Aldape." http://www.cddhcu.gob.mx/bibliot/ publica/gabinete/eduardos.htm

Mexico. H. Congreso de la Unión. Senado de la República. Informe Ejecutivo de la Visita. "Visita de Trabajo del C. Presidente de la República Vicente Fox Queseda a Waco, Texas, en los Estados Unidos de América." 23 March 2005. http://www.senado.gob.mx/gace.php?sesion=2005/04/28/1\&documento=6.

Mexico. Presidency of the Republic. Archives of Vicente Fox. Press Release. "Third Meeting of the Partnership for Prosperity Initiative.” 20 February 2002. http://fox.presidencia.gob.mx/en/

North American Competitiveness Council. Building a Secure and Competitive North America: Private Sector Priorities for the Security and Prosperity Partnership of North America-2007 Report to Leaders from the North American Competitiveness Council. August 2007.

North American Competitiveness Council. Enhancing Competitiveness in Canada, Mexico and the United States-Private Sector Priorities for the Security and Prosperity Partnership of North America (SPP). Initial Recommendations of the North American Competitiveness Council. February 2007.

Pastor, Robert. “North America's Second Decade." Foreign Affairs 83, No. 1 (January/February 2004): 128-135.

Pastor, Robert. Toward a North American Community: From the Old World to the New. Washington, D.C.: Institute for International Economics, 2001.

Peterson Institute for International Economics. "Testimony of Nicholas R. Lardy, Committee on International Relations, House of Representatives, 21 October 2003." http://www.iie.com/publications/papers/paper.cfm?ResearchID=268

Rekai, Peter. "U.S. and Canadian Immigration Policies: Marching together to Different Tunes." C.D. Howe Institute. The Border Papers, No. 171 (November 2002).

Rozental, Andrés. "The Security and Prosperity Partnership: An Overview," International Journal 61, no. 3 (Summer 2006): 541-544.

Sallot, Jeff. "Bush lied to justify Iraq war, Canada right to stay out: poll." The Globe and Mail, March 15, 2004, sec. A.

Sallot, Jeff. "Mexico's Fox Aims to Fend Off China's Challenge; Wants Canada, U.S. to Help Protect Jobs." The Globe and Mail, October 26, 2004, sec. A. 
Sands, Chris. "North America at Two Speeds." Center for Strategic and International Studies. North American Integration Monitor 1, no. 2 (November 2002). http://www.csis.org/media/csis/pubs/0211.pdf

Savoie, Donald J. Breaking the Bargain: Public Servants, Ministers, and Parliament. Toronto: University of Toronto Press, 2003.

Serrano, Monica. "Integration and security in North America." International Journal 61, No. 3 (Summer 2006): 611-632.

Smith, Geri. “It May Be Time for a 'NAFTA Plus."” Business Week. December 22, 2003. http://www.businessweek.com/magazine/content/03_51/b3863023.htm

Starr, Pamela K. "U.S.-Mexico Relations." Center for Strategic and International Studies. Hemisphere Focus 12, no. 2 (9 January 2004).

http://www.csis.org/media/csis/pubs/hf_v12_02.pdf

Stop SPP.Com. http://stopspp.com/stopspp/

The Public Policy Forum. Rethinking North American Integration: Conference Report. Ottawa: 29-30 October 2003. http://www.ppforum.ca/common/assets/ publications/en/na_outcomes_final.pdf

Thompson, Ginger. "U.S.-Mexico Relations: Alliance Meets Boundaries." The New York Times, 23 March 2002, sec. A.

Tomlin, Brian W., Norman Hillmer, and Fen Osler Hampson. Canada's International Policies: Agendas, Alternatives, and Politics. Don Mills: Oxford University Press, 2008.

United Nations Committee on Trade and Development. "Regional FDI Trends: A Mixed Picture." Chapter 2. World Investment Report 2004. http://www.unctad.org/en/docs/wir2004ch2_en.pdf

United States. Congress. House of Representatives. Select Committee on Homeland Security. Balancing Security and Commerce: Hearing Before the Subcommittee on Infrastructure and Border Security. $108^{\text {th }}$ Cong. $1^{\text {st }}$ Sess. 16 June 2003.

United States. Congress. Senate. Committee on Finance. Hearing: Nominations of Kenneth W. Dam, David Aufhauser, Michele A. Davis, and Faryar Shirzad. $107^{\text {th }}$ Cong. $1^{\text {st }}$ Sess. 29 March 2001.

United States. Congress. Senate. Committee on Foreign Relations. United States and Mexico: Immigration Policy and the Bilateral Relationship. $108^{\text {th }}$ Cong. $2^{\text {nd }}$ sess. 23 March 2004. 
United States. Congress. Senate. Committee on Foreign Relations. NAFTA A Ten Year Perspective and Implications for the Future: Hearing before the Subcommittee on International Economic Policy, Export, and Trade Promotion. $108^{\text {th }}$ Cong. $2^{\text {nd }}$ Sess. 20 April 2004.

United States. Congress. Senate. Committee on Foreign Relations. Subcommittee on the Western Hemisphere. $109^{\text {th }}$ Cong. $1^{\text {st }}$ Sess. 9 June 2005. http://foreign.senate.gov/testimony/2005/PastorTestimony050609.pdf

United States. Department of Commerce. "Remarks to U.S. and Canadian Chambers of Commerce." Washington, DC.: 30 October 2007. http://www.commerce.gov/NewsRoom/SecretarySpeeches/PROD01_004605

United States. Department of Commerce. "Secretary of Commerce Carlos Gutierrez, American Chamber of Commerce of Mexico." Mexico City: 1 February 2007. http://www.commerce.gov/NewsRoom/SecretarySpeeches/PROD01_002820

United States. Department of Commerce. "Statement by Ministers Responsible for the Security and Prosperity Partnership of North America." Ottawa: 23 February 2007. http://www.commerce.gov/NewsRoom/PressReleases_ FactSheets/PROD01_002800

United States. Department of Commerce. "Written statement on Oversight of the U.S. Department of Commerce by Commerce Secretary Carlos M. Gutierrez, Senate Committee on Commerce, Science, and Technology." 1 August 2007. http://www.commerce.gov/s/groups/public/@doc/@os/@opa/documents/content/ prod01_003231.pdf

United States. Department of Homeland Security. "Statement by Cresencio Arcos, Assistant Secretary, International Affairs, before U.S. House of Representatives Committee on International Relations, Subcommittee on the Western Hemisphere.” 26 July 2006. http://www.dhs.gov/xnews/testimony/testimony_0053.shtm

United States. Department of Homeland Security. "The Mexico-U.S. Border Partnership: Progress Report 2002-2004." 17 January 2005. http://www.dhs.gov/xlibrary/assets/2004_US-Mex_Book.pdf

United States. U.S. Embassy in Canada. Canada-United States Accord on Our Shared Border Update 2000. http://canada.usembassy.gov/content/ can_usa/us_can_border_accord.pdf

United States. Government Accountability Office. Department of Homeland Security: Progress Report on Implementation of Mission and Management Functions. September 2007. http://www.gao.gov/new.items/d071081t.pdf 
United States. Government Accountability Office. "Testimony before the Committee on Finance, United States Senate, 'Border Security: Security Vulnerabilities at Unmanned and unmonitored U.S. border crossings."' 2 October 2007. http://www.gao.gov/new.items/d07884t.pdf

United States. Library of Congress. North American Investment Fund Act of 2006, $109^{\text {th }}$ Cong. $2^{\text {nd }}$ Sess. S.R. 3622. http://thomas.loc.gov/cgibin/query/z?c109:S.3622.IS:

United States. Office of the United States Trade Representative. "NAFTA Free Trade Commission Joint Statement-A Decade of Achievement." San Antonio: 16 July 2004. http://www.ustr.gov/Document_Library/Press_Releases/2004/July/ NAFTA_Free_Trade_Commission_Joint_Statement_-_A_Decade_of_ Achievement.html

United States. SPP.Gov. Security and Prosperity Partnership: Report to Leaders (2005). http://www.spp.gov/report_to_leaders/index.asp?dName=report_to_leaders

United States. SPP.Gov. Security and Prosperity Partnership: Report to Leaders (2006). http://www.spp.gov/2006_report_to_leaders/index.asp?dName=2006_report _to_leaders

United States. SPP.Gov. "The Security and Prosperity Partnership of North America: Progress.” 31 March 2006. http://www.spp.gov/pdf/security_and_prosperity_ partnership_of_north_america_statement.pdf

United States. State Department. U.S. INFO. "Background Briefing by a Senior Administration Official on the President's meetings with Prime Minister Martin." Ottawa: 30 November 2004. http://www.america.gov/st/washfileenglish/2004/December/20041201114924ASrelliM0.1756555.html.

United States. State Department. U.S. INFO. "North American Officials Outline Common Security, Prosperity Plans." (Ottawa: 27 June 2005). http://usinfo.state.gov/is/Archive/2005/Jun/29-375937.html

United State. State Department. USINFO. "North American Partnership Reports Enhanced Security, Prosperity." 27 June 2005. http://usinfo.state.gov/ei/Archive/ 2005/Jun/27-389232.html

United States. White House. Press Office. "Joint Statement by President George W. Bush and President Vicente Fox Towards a Partnership for Prosperity." Guanajuato: 16 February 2001. http://www.whitehouse.gov/news/ releases/2001/02/20010220-2.html

United States. White House. Press Office. "Joint Statement by President Bush, President Fox, and Prime Minister Martin." Waco: 23 March 2005. http://www.whitehouse.gov/news/releases/2005/03/20050323-2.html 
United States. White House. Office of the Press Secretary. "President Bush Appoints Edson as Deputy Assistant to the President for International Economics and Deputy National Security Advisor." Washington: 21 February 2001. http://www.whitehouse.gov/news/releases/2001/02/20010221-7.html

United States. White House. Press Office. "President Bush, President Fox of Mexico, and Prime Minister Harper of Canada in Press Availability." Cancun: 31 March 2006. http://www.whitehouse.gov/news/releases/2006/03/20060331-4.html

United States. White House. "Press Briefing by Dan Fisk, Senior Director for Western Hemisphere Affairs, NSC." Cancun: 30 March 2006. http://www.whitehouse.gov/ news/releases/2006/03/20060330-9.html

United States. White House. Security and Prosperity Partnership of North America Prosperity Agenda. 23 March 2005. http://www.whitehouse.gov/news/releases/ 2005/03/20050323-1.html

Ward, John. "Trade, Competitiveness, and Security Issues at the Forefront of North American Ministerial Meeting," International Trade Administration Newsletter. March 2007. http://trade.gov/press/publications/newsletters/ ita_0307/spp_0307.asp

Washington Post Online. "Transcript: Bush, Fox, and Martin Joint Press Conference." Waco: 23 March 2005. http://www.washingtonpost.com/wpdyn/articles/A59996-2005Mar23.html

Weintraub, Sidney. “ 'A North American "Community:' Pros and Cons." Center for Strategic and International Studies. Issues in International Political Economy, no. 62 (January 2005). http://www.csis.org/media/csis/pubs/issues200501.pdf

Weintraub, Sidney. "Invigorating North American Integration." Center for Strategic and International Studies. Issues in International Political Economy, no. 66 (June 2005). http://www.csis.org/index.php?option=com_csis_pubs\& task=view\&id=1006

Weintraub, Sidney. "Strains in the Canada-U.S. Relationship." Center for Strategic and International Studies. Issues in International Political Economy, no. 40 (April 2003). http://www.csis.org/media/csis/pubs/issues200304.pdf

Woodrow Wilson International Center for Scholars. Borderlines: Canada in North America (Washington: 27 February 2003). http://www.wilsoncenter.org/ index.cfm?fuseaction=events.event_summary\&event_id=20881 